\title{
PRINCIPAIS DETERMINANTES DO PREÇO DO FRETE RODOVIÁRIO PARA TRANSPORTE DE SOJA EM GRÃOS EM DIFERENTES REGIÕES BRASILEIRAS: UMA ANÁLISE ECONOMÉTRICA
}

\section{GONCILIO CORRÊA JUNIOR}

\author{
Economista
}

Dissertação apresentada à Escola Superior de Agricultura "Luiz de Queiroz", Universidade de São Paulo, para obtenção do título de Mestre em Ciências, Área de Concentração: Economia Aplicada.

P I R A C I C A B A

Estado de São Paulo - Brasil

Outubro -2001 
Dados Internacionais de Catalogação na Publicação (CIP) DIVISĀO DE BIBLIOTECA E DOCUMENTAÇÃO - ESALQ/USP

Corrêa Junior, Goncilio

Principais determinantes do preço do frete rodoviário para transporte de soja em grãos em diferentes regiões brasileiras : uma análise econométrica / Goncilio Corrêa Junior. - - Piracicaba, 2001.

102 p. : il.

Dissertação (mestrado) - E Escola Superior de Agricultura Luiz de Queiroz, 2001.

Bibliografia.

1. Econometria 2. Soja 3. Tarifa de transportes 4. Transporte rodoviário de carga I. Título

CDD 388.1

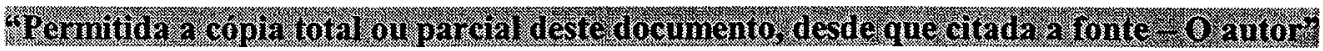


Dedico esse trabalho aos meus pais, que me deram a fantástica oportunidade de viver, $e$ principalmente a minha incansável companheira Claudia e a pequena Ana Clara, fruto, mas também genitora dos meus mais profundos sonhos... 


\section{AGRADECIMENTOS}

Os nomes seriam infindáveis, a memória com certeza me trairia e por um lapso, injustamente, me esqueceria de algum braço amigo. Assim, a todos aqueles que se empenharam tanto quanto eu para que esse trabalho se realizasse, e que acreditaram em nossas capacidades, agradeço.

A todos os professores que tive, principalmente os professores da FEARP/USP assim como aqueles que me acompanharam durante o curso de mestrado, especialmente meu orientador, Prof. José Vicente Caixeta, que me ungiu com todo seu conhecimento, e com mais profissionalismo e competência do que essas folhas podem conter.

Também aos colegas e profissionais da Esalq/USP que me acolheram, apoiaram e são co-responsáveis pelo sucesso desse projeto.

Ao $\mathrm{CNPq}$ agradeço o apoio financeiro que possibilitou que me dedicasse exclusivamente aos estudos.

Enfim, agradeço a Deus simplesmente por me dar a oportunidade de poder agradecer. 


\section{SUMÁRIO}

Página

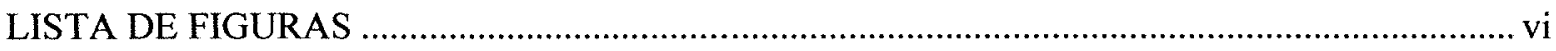

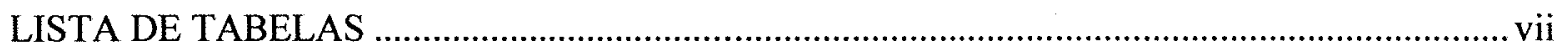

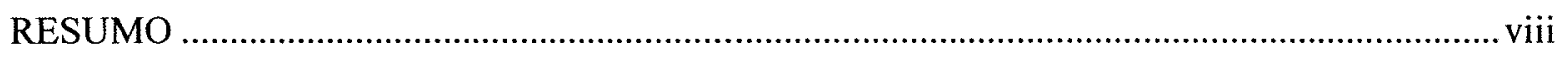

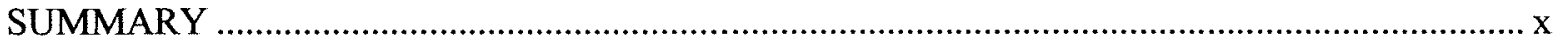

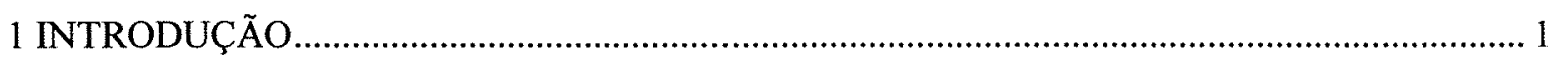

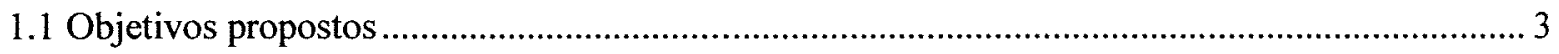

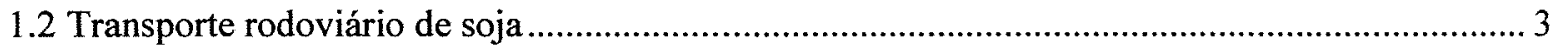

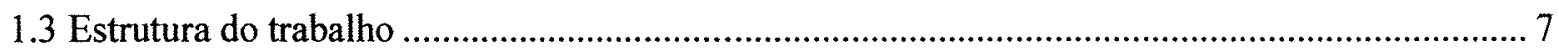

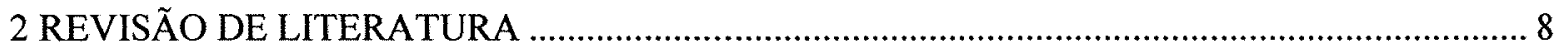

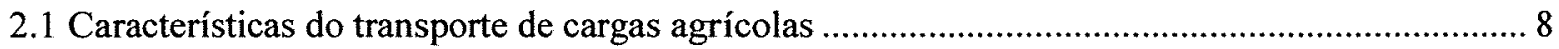

2.2 Caminhões, caminhoneiros e outras características da oferta de transporte ............................... 16

2.3 A relação entre os fatores que podem influenciar os preços dos fretes e os custos operacionais

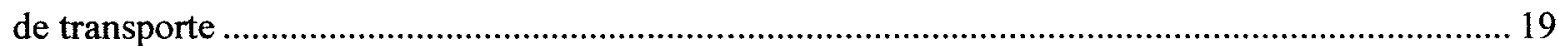

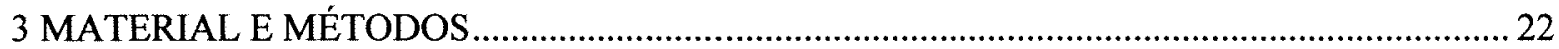

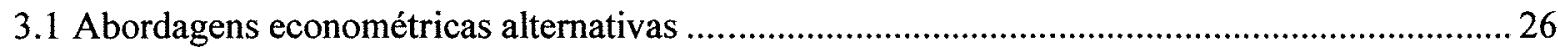

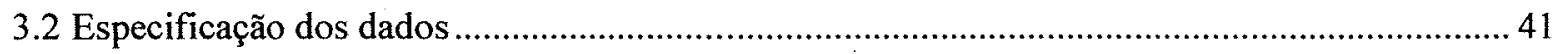

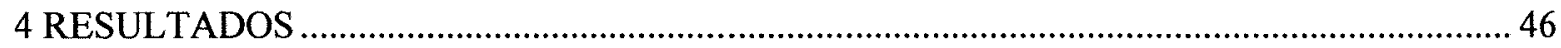

4.1 Avaliação da amostra de valores de frete rodoviário de soja utilizada.................................... 46

4.2 Estimação dos valores de frete rodoviário de soja em diferentes regiões brasileiras ................. 56

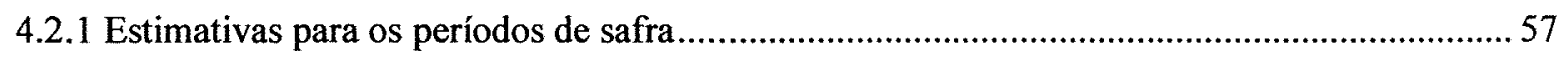

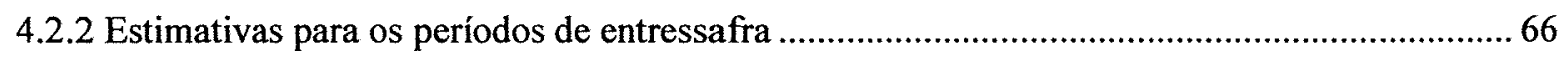

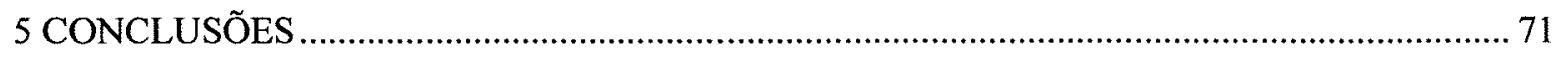

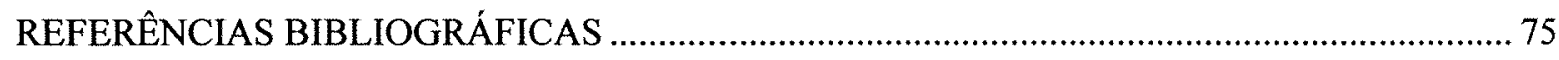

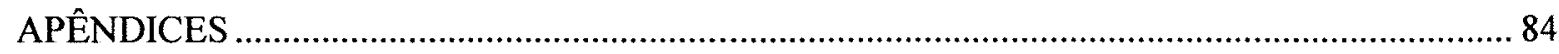




\section{LISTA DE FIGURAS}

Página

1 Representação esquemática dos principais fluxos de movimentação observados no sistema

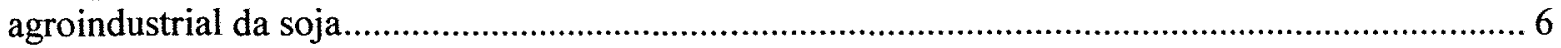

2 Consumo anual de óleo diesel no Brasil ente 1947 e 1999 em milhares de litros........................ 17

3 Média mensal real dos preços do frete de soja a granel, em $\mathrm{R} \$ / \mathrm{t}$, de Marcianópolis $(\mathrm{GO})$ com destino a Itumbiara (GO), entre janeiro de 1998 e maio de 2000

4 Média mensal real dos preços do frete de soja a granel, em $\mathrm{R} \$ / \mathrm{t}$, de Jataí (GO) com destino a Paranaguá (PR), entre janeiro de 1998 e maio de 2000

5 Valores reais por tonelada dos fretes praticados nas safras de 1998,1999 e 2000 para transporte de soja a granel em diversas regiões brasileiras ............................................................................. 47

6 Valores reais por tonelada dos fretes praticados nas entressafras de 1998, 1999 e 2000 para transporte de soja a granel em diversas regiões brasileiras ........................................................... 48

7 Representações lineares dos dados utilizados, plotados nas Figuras 5 e 6 ................................... 49 


\section{LISTA DE TABELAS}

Página

1 Quantidade da carga transportada em toneladas-quilômetro, por modo de transporte - 1994-99 .... 4

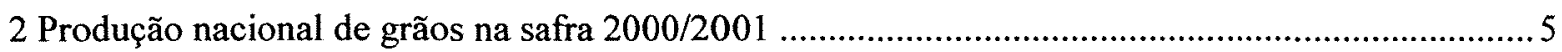

3 Valor da produção das dez principais culturas no Brasil em 1997, em mil reais ........................... 5

4 Preço do frete para transporte de soja em grãos, em março de 2000 ............................................23

5 Trabalhos científicos abordados, suas variáveis explanatórias e a abordagem matemática

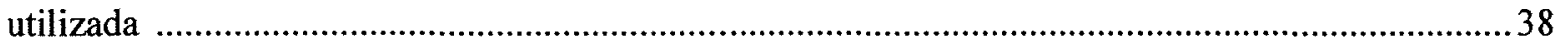

6 Descrição dos dados amostrados para as safras de 1998 a 2000 por estado..................................50

7 Descrição dos dados amostrados para as entre safras de 1998 a 2001 por estado.........................53

8 Volume total de granéis sólidos agrícolas transportados, em toneladas, entre os estados

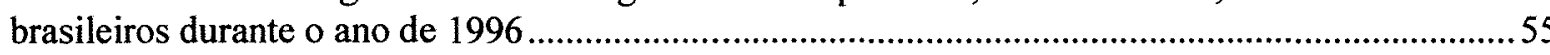

9 Principais resultados dos modelos de estimação do valor do frete praticado para o transporte rodoviário de soja a granel, com origem nos estados de Goiás, Mato Grosso e Paraná, nos períodos de safra dos anos de 1998 a 2000

10 Principais resultados dos modelos de estimação do valor do frete praticado para o transporte rodoviário de soja a granel, com origem nos estados de Goiás, Mato Grosso e Paraná, nas entre safras de 1998/1999, 1999/2000 e 2000/2001 


\title{
PRINCIPAIS DETERMINANTES DO PREÇO DO FRETE RODOVIÁRIO PARA TRANSPORTE DE SOJA EM GRÃOS EM DIFERENTES REGIÕES BRASILEIRAS : UMA ANÁLISE ECONOMÉTRICA
}

\author{
Autor: GONCILIO CORREAA JUNIOR \\ Orientador: Prof. Dr. JOSÉ VICENTE CAIXETA FILHO
}

\section{RESUMO}

O presente trabalho procura identificar a influência de fatores como: distância percorrida, possibilidade de obtenção de carga de retorno, sazonalidade da demanda por transporte, especificidade da carga transportada e do veículo utilizado, vias utilizadas, pedágios e fiscalização, aspectos geográficos (preferência por determinado percursos), prazo de entrega, tempo de carga e descarga, perdas e avarias para determinação dos valores praticados para o transporte de soja a granel com origem nos estados de Goiás, Mato Grosso e Paraná, durante as safras de 1998 a 2000 e entre safras de 1998/1999 a 2000/2001. Os resultados mostraram que, em maior ou menor grau, os valores de frete praticados entre 1998 e 2001 foram influenciados por fatores como: a distância percorrida, a existência de praças de pedágios em algumas rodovias; o tempo de descarregamento nos portos; sazonalidade da demanda por transporte; e a as condições das vias utilizadas, sendo que os demais fatores não puderam ser avaliados. Dada a necessidade de se transportar a maior parte de soja imediatamente após a sua colheita, os preços dos fretes são especificados de maneiras distintas na época de safra e na época de entressafra. As condições das vias utilizadas parecem ser um diferencial no caso do estado do Mato Grosso. Entretanto, provavelmente a elevação dos custos operacionais 
(preço do óleo diesel, por exemplo) e a implantação de novas praças de pedágios, entre 1999 e 2000, podem ter contribuído para um ambiente menos favorável para expressar preferências por percursos com melhores estradas. Outra importante conclusão é que, mesmo que as variáveis relevantes nos modelos especificados sejam muitas vezes similares, a atividade de transporte é bastante regionalizada, sendo que existem diferenças qualitativas entre os mercados de transportes de Goiás, Mato Grosso e Paraná. Diferentemente do que se imaginava, o presente trabalho revelou que os portos, principalmente o de Paranaguá, não foram identificados como possíveis pontos de obtenção de cargas de retorno, mas sim, como destinos preteridos em função da morosidade no descarregamento de grãos, o que foi captado pela equação estimada para a movimentações de soja com origem no estado do Paraná na safra de 2000. Nos períodos de entressafra, a distância percorrida foi identificada como o principal determinante nos preços dos fretes sendo que, de modo geral, outros fatores parecem terem sido relevados. Entretanto, por mais que esses fatores impliquem impactos reais sobre a lucratividade da atividade, o acirramento da concorrência em meses de demanda escassa, tem impedido que a influência desses fatores sobre os custos operacionais seja repassada integralmente aos preços dos fretes. 


\title{
MAJOR DETERMINANTS OF ROAD FREIGHT RATES FOR SOYABEAN GRAINS AT DIFFERENT BRAZILIAN REGIONS: AN ECONOMETRIC ANALYSIS
}

\author{
Author: Goncilio Corrêa Junior \\ Adviser: Prof. Dr. José Vicente Caixeta Filho
}

\section{SUMMARY}

The present study aims to identify the influence of factors such as: distance, possibility of obtaining backhauling opportunities, seasonal demand for transport, load peculiarity, type of vehicles, conditions of highways, existence of tolls and inspection, geographical aspects (preference for specific routes), deadline, loading and unloading time, losses and damages in order to determine operating freight rates of soyabean originally grown in the states of Goiás, Mato Grosso and Paraná, during the high seasons of 1998 to 2000 and low seasons of $1998 / 1999$ to 2000/2001. Results have shown that, in higher or lower degree, operating freight rates between 1998 and 2001 were influenced by factors such as: distance, toll roads; unloading time at ports; seasonal demand for transport and highways conditions. Other factors could not be evaluated. Due to the need of transporting most of the soyabean immediately after its harvest, freight rates are distinctly operated at high and low season times. Road conditions seem to be a differential in Mato Grosso state particularly. However, the probable increase of operational costs (diesel price, for example) and the operation of new toll gates, between 1999 and 2000, may have contributed for a less favorable environment to express preferences for routes with better roads. Another important fact is that, even though 
some relevant variables in specified models are quite similar, transport activity is rather regional, which means significant differences among transport markets in Goiás, Mato Grosso and Paraná. Differently from what was thought, the present study showed that ports, mainly the Paranaguá port, were not identified as possible places to obtain backhauling businesses, but as avoided destinations due to slow service of grain unloading, which was considered the relevant factor by the estimated equation of soyabean transported originally from state of Paraná in the high season of 2000. During low seasons, distance was appointed as the major determinant of freight rates, in general terms, while other factors seem to have been ignored. However, no matter how hard these factors affect the business profitability, competition in times of scarce demand has barred these factors on operational costs from being transferred in their totality to freight rates. 


\section{INTRODUÇÃO}

Como já postulava Smith (1974) no século XVIII, a divisão do trabalho proporciona normalmente um aumento da produtividade dos fatores, uma vez que os agentes produtivos têm condições de se especializar em determinados segmentos.

A gradual abertura comercial das economias, derivada do processo de globalização, tem contribuído para que esse fenômeno se dê de forma cada vez mais abrangente, estendendo-se além das fronteiras geopolíticas, proporcionando uma crescente especialização produtiva entre as nações, o que, por um lado, expande as possibilidades de ganho, ao abrir mercados consumidores potenciais e, por outro, aumenta a exposição a novos concorrentes.

Paralelamente, como conseqüência desse processo, observa-se um crescimento da demanda por transportes, derivada da necessidade de movimentação dos produtos e insumos em um mercado globalizado, apresentando-se como variável decisiva para a competitividade dos produtos frente à concorrência de outros países.

A questão dos transportes é fundamental para os futuros desdobramentos do comércio internacional, podendo se transformar inclusive em ferramenta de estratégia política. Fulton et al. (1995) destacam o programa canadense Western Grain Transportation Act (WGTA) como um mecanismo indireto de proteção aos produtores ao subsidiar o transporte de produtos agrícolas destinados à exportação.

Por outro lado, custos de transportes relativamente distintos entre regiões podem definir padrões comerciais. Binkley \& Harrer (1981), citando Sampson \& Yeats', destacam que, no Reino Unido, os custos com transportes são barreiras comerciais mais

\footnotetext{
${ }^{1}$ SAMPSON, G. P.; YEATS, A. J.. The incidence of transport costs on exports from United Kingdon. Journal of Transportation Economic and Policy, v. 12, p. 196-202, 1978.
} 
significativas que as tarifárias (tais como impostos à importação), sendo que Finger \& Yeats $^{2}$ chegaram à mesma conclusão para as importações americanas.

Ainda como reflexo do processo de globalização, agentes de diferentes países estabelecem vínculos comerciais estratégicos como os que vêm ocorrendo, por exemplo, através da maior integração vertical entre empresas de manufatura de países desenvolvidos e fornecedores de países em desenvolvimento (que detêm menores custos operacionais, como o custo da mão-de-obra), sendo que nessa relação a questão do transporte de insumos torna-se fundamental.

Segundo Gwilliam (1998), a Índia, por exemplo, tem perdido parte de suas exportações no setor têxtil para países do Sudeste da Ásia, onde os governos procuram facilitar o fluxo comercial. Da mesma forma, o autor cita que produtores de cacau da Costa do Marfim têm perdido mercado para produtores da América Central, capazes de entregar seus produtos de maneira mais eficiente.

Já por outro lado, Omamo (1998) mostra que os altos custos de transporte agrícola encontrados no distrito de Siaya, Kenya, influenciam negativamente a decisão de produção, reduzindo ganhos e o grau de especialização das propriedades.

Esse processo pode ser observado de forma ainda mais acentuada no Brasil. Além do próprio fenômeno da globalização, após um longo período de altas taxas inflacionárias e fracassados planos de estabilização econômica, o governo federal, principalmente a partir de 1994, vem adotando uma estratégia de estabilização que, entre outros fatores, utiliza a abertura econômica como uma das principais ferramentas no combate à inflação. Assim, a abertura das fronteiras aos produtos importados vem ocorrendo de forma ainda mais aguda que em outros países, o que trouxe conseqüências mais profundas ao setor produtivo nacional, tornando mais evidente a necessidade do desenvolvimento de uma estrutura competitiva para os produtos nacionais.

Além disso, como agravante, nesse período ocorreu um profundo desequilíbrio da balança comercial do país, sendo que as exportações do setor agroindustrial vêm sendo um dos fatores primordiais para reversão desse quadro. Em 1999, segundo a

\footnotetext{
${ }^{2}$ FINGER, J. M.; YEATS, A. J.. Effective protection by transportation costs and tariffs: A comparison on magnitudes. Quarterly Journal of Economics, v. 90, p. 169-176, 1976.
} 
Companhia Brasileira de Abastecimento (2000), foram exportados US\$ 48.011,4 milhões, sendo que o setor agroindustrial contribuiu com US $\$ 18.942,4$ milhões, o equivalente a 39,5\% desse total, com acentuada participação da exportação de grãos.

Nesse contexto, estudos que colaborem para um melhor entendimento sobre o transporte de produtos agrícolas no Brasil são de grande valia para o desenvolvimento da economia nacional.

\subsection{Objetivos propostos}

A principal hipótese deste trabalho é: fatores como distância percorrida, possibilidade de carga de retorno, sazonalidade da demanda por transporte, especificidades da carga transportada e do veículo utilizado, vias utilizadas, pedágios e fiscalização, aspectos geográficos (origem e destino das cargas), prazo de entrega, tempo de carga e descarga, perdas e avarias influenciam na diferenciação dos preços do frete rodoviário de grãos nas diferentes regiões brasileiras.

Neste sentido, o presente trabalho pretende abordar a questão do transporte no setor agrícola analisando o valor do frete rodoviário de soja a granel com origem nos estados de Goiás, Mato Grosso e Paraná, entre os anos de 1998 e 2001, através da identificação de seus principais componentes, e da discussão sobre a influência desses fatores no comportamento de preços de frete para o transporte desse produto agrícola em diferentes percursos e períodos.

Para auxiliar essa análise deverá ser identificado um modelo econométrico consistente e adequado para captar e validar os principais determinantes do valor de frete praticado.

\subsection{Transporte rodoviário de soja}

A opção pelo modal rodoviário, como foco da pesquisa, deve-se à sua importância na atividade de transporte de cargas dentre os modais no país e no exterior. De acordo com a reportagem SINAL ... (2000), na Europa, por exemplo, as constantes elevações nos preços dos combustíveis desencadearam uma série de protestos em 
setembro de 2000, sendo que, na Inglaterra, o bloqueio de refinarias e depósitos de combustíveis promovido principalmente por caminhoneiros descontentes foi suficiente para parar uma das maiores economias mundiais.

Segundo a reportagem PAÍS ... (1999), em julho de 1999, a insatisfação dos caminhoneiros brasileiros com a elevação dos custos de transporte e o baixo retorno financeiro da atividade mostrou a dependência da estrutura econômica brasileira em relação ao modal rodoviário, ocasião em que transportadores de todo o país promoveram uma paralisação nacional, que causou uma grave crise na oferta de vários produtos, principalmente nas grandes cidades, com perdas estimadas em $\mathrm{R} \$ 100$ milhões somente para o setor agrícola.

A Tabela 1 mostra que, no Brasil, $61,8 \%$ de toda carga transportada durante o ano de 1999 utilizou-se do modal rodoviário.

Tabela 1. Quantidade da carga transportada em milhões de toneladas-quilômetro, por modo de transporte - 1994-99.

\begin{tabular}{lcccccc}
\hline $\begin{array}{c}\text { Modo de } \\
\text { transporte }\end{array}$ & 1994 & 1995 & 1996 & 1997 & 1998 & 1999 \\
\hline Aéreo & 1.794 & 1.953 & 2.036 & 1.712 & 2.191 & 2.252 \\
Aquaviário & 59.301 & 70.610 & 71.310 & 77.402 & 90.444 & 100.057 \\
Dutoviário & 22.877 & 24.179 & 23.605 & 30.367 & 31.609 & 33.131 \\
Ferroviário & 133.735 & 136.460 & 128.976 & 138.724 & 142.446 & 140.817 \\
Rodoviário & 355.935 & 379.007 & 396.415 & 421.131 & 445.799 & 447.353 \\
TOTAL & 573.642 & 612.209 & 622.342 & 669.336 & 712.485 & 723.610 \\
\hline
\end{tabular}

Fonte: Anuário Estatístico dos Transportes 2000 (2000)

O Brasil produz cerca de doze tipos principais de grãos. Tal como mostra a Tabela 2, a produção de soja, na safra de 2000/2001, representou mais de $36 \%$ do volume de grãos produzidos, o que justifica a seleção dessa cultura para o desenvolvimento da presente pesquisa, dentre a gama de grãos. 
Tabela 2. Produção nacional de grãos na safra 2000/2001.

\begin{tabular}{lc}
\hline \multicolumn{1}{c}{ Cultura } & Toneladas (milhões) \\
\hline Soja & 34,531 \\
Outras culturas & 38,497 \\
Milho & 10,787 \\
Arroz & 7,606 \\
Outras & 56,890 \\
Total Outras Culturas & 94,421 \\
Total geral & Fonte: Companhia Nacional de Abastecimento - CONAB (2000)
\end{tabular}

Além disso, como mostra a Tabela 3, dentre as principais culturas produzidas no Brasil em 1997, que somam cerca de $\mathrm{R} \$ 28.063 .053 \mathrm{mil}$, a soja contribuiu com cerca de $23 \%$ deste total (R\$ $6.437 .880 \mathrm{mil})$, o que atesta a importância dessa cultura dentro da agricultura brasileira.

Tabela 3. Valor da produção das dez principais culturas no Brasil em 1997, em mil reais. Cultura Valor da produção ( $\mathrm{R} \$$ mil)

\begin{tabular}{lc}
\multicolumn{1}{c}{ Cultura } & Valor da produção $(\mathrm{R} \$$ mil) \\
\hline Soja & 6.437 .880 \\
Outras culturas & \\
Cana-de-açúcar & 5.857 .199 \\
Café (coco) & 3.539 .131 \\
Milho (grãos) & 3.753 .731 \\
Outras & 8.475 .112 \\
Total outras culturas & 21.625 .173 \\
Total geral & 28.063 .053 \\
\hline
\end{tabular}

Fonte: Fundação Instituto Brasileiro de Geografia e Estatística (2000)

De acordo com a Fundação Instituto Brasileiro de Geografia e Estatística (2000), o noroeste rio-grandense-do-sul representou, em 1998, o maior volume de produção de soja entre as mesorregiões da Federação: cerca de $17 \%$ da produção nacional, seguido do norte mato-grossense $(13 \%)$, sul goiano $(10 \%)$ e o sudeste mato-grossense $(8 \%)$. As mesorregiões norte e oeste do Paraná somaram 13\% da produção de 1998, avaliada em cerca de 31.307 mil t.

A Figura 1, por sua vez, mostra um esquema básico para o fluxo produtivo dentro do sistema agroindustrial da soja, sendo que as setas representam o sentido deste fluxo entre os agentes. Nota-se que os chamados embarcadores, ou donos de carga, são 
representados tanto pelos próprios produtores, quanto pelas tradings, cooperativas, corretoras, armazenadores, exportadores e até mesmo por empresas de esmagamento com departamentos especializados nessa função.

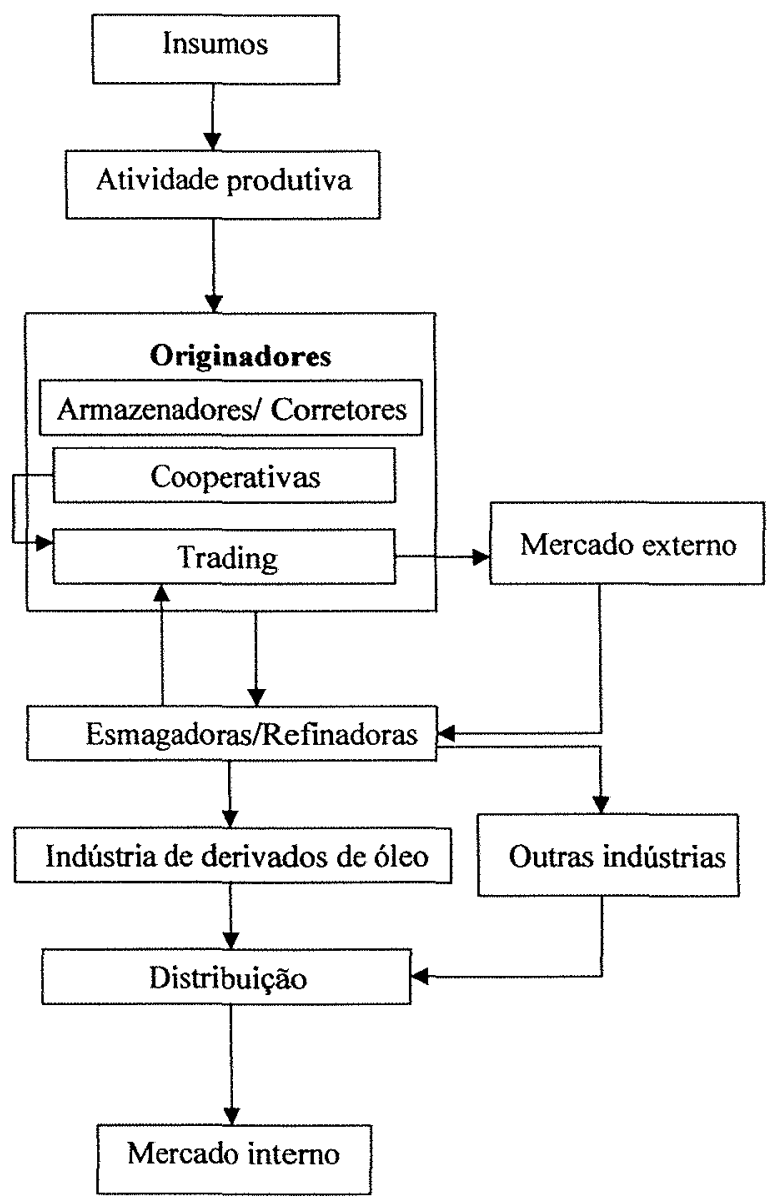

Figura 1 - Representação esquemática dos principais fluxos de movimentação observados no sistema agroindustrial da soja.

Fonte: Lazzarini \& Nunes (1998) 
Portanto, o estudo da atividade de transporte rodoviário de soja no Brasil mostrase relevante, uma vez que a atividade apresenta várias peculiaridades que afetam de formas distintas o preço do frete cobrado.

\subsection{Estrutura do trabalho}

Com o presente capitulo, pretende-se destacar a importância do tema abordado.

O segundo capítulo traz um melhor entendimento das relações econômicas inerentes à atividade de transporte, bem como apresenta algumas características da produção e da movimentação de soja no Brasil.

Dando seqüência ao trabalho de pesquisa, o terceiro capítulo ocupa-se em identificar as alternativas econométricas disponíveis para a estimação de um modelo consistente, oportunidade em que é apresentada a justificativa para a escolha do modelo adotado, os testes econométricos que serão desenvolvidos, assim como a especificação das fontes de dados utilizadas.

Os principais resultados obtidos são apresentados e discutidos no quarto capítulo, enquanto as principais conclusões e limitações do trabalho são destacadas no quinto e último capítulo.

O presente trabalho não pretende esgotar a discussão sobre o tema abordado, principalmente devido à complexidade dos fatores que norteiam o estabelecimento de preços, arraigados por variáveis microeconômicas de difícil mensuração, tais como as preferências individuais por determinados percursos em função das sensibilidades dos agentes à segurança, satisfação pessoal etc.

O que se procura, no entanto, é destacar a importância de estudos sobre o tema, e colaborar para um melhor entendimento sobre as relações inerentes à formação de preços de fretes rodoviários para produtos agrícolas no Brasil, em especial para os grãos. 


\section{REVISÃO DE LITERATURA}

\subsection{Características do transporte de cargas agrícolas}

O rápido processo de abertura econômica, conjugado a outros fatores advindos do processo de estabilização econômica, vem transformando a distribuição espacial da produção agrícola e industrial entre as regiões do país, sendo de fundamental importância que a matriz brasileira de transportes venha a acompanhar esse processo, dando suporte à nova estrutura produtiva.

Caixeta Filho et al. (1998a) observam a revolução que vem ocorrendo nos negócios agropecuários no Brasil, destacando a expansão da produção para o Norte, Nordeste e Centro-Oeste, principalmente conjugadas às modernas tecnologias de produção, como forma de minimizar os custos de transporte entre as partes através da redução das distâncias entre os agentes, na procura de maior competitividade do produto nacional nos mercados interno e externo.

Lazarinni \& Nunes (1998) observam que, devido à exposição a um ambiente cada vez mais competitivo, o segmento produtivo da soja tem procurado elevar a eficiência produtiva através de mudanças estruturais, destacando o deslocamento da produção para os cerrados, o estabelecimento de novos corredores para exportação, promovendo também um processo de "fusões e aquisições" entre os agentes como fatores determinantes para a alteração do fluxo de produtos e insumos observado no Brasil.

Por outro lado, a expansão geográfica da atividade produtiva aumenta as distâncias entre as áreas de produção e o mercado consumidor, o que torna indispensável 
a conexão entre esses agentes através de uma matriz de transporte eficiente, que garanta o desenvolvimento da comercialização desses produtos em bases competitivas.

Trabalhos como os de Thompson (1960) e de Hauser (1986) creditam à distância entre a origem e o destino envolvidos o papel determinante para o estabelecimento de preços de frete. Segundo Binkley \& Harrer (1981), entretanto, muitos fatores podem influenciar essa taxa, não havendo necessariamente uma relação diretamente proporcional com a distância percorrida.

Baseando-se principalmente em Ortúzar (1990) e Caixeta et al. (1998b), é possível identificar algumas varáveis que podem influenciar o estabelecimento do preço do frete, das quais destacam-se:

- distância percorrida;

- custos operacionais;

- possibilidade de carga de retorno;

- carga e descarga;

- sazonalidade da demanda por transporte;

- especificidade da carga transportada e do veículo utilizado;

- perdas e avarias;

- vias utilizadas;

- pedágios e fiscalização;

- prazo de entrega;

- aspectos geográficos.

No contexto brasileiro, além desses aspectos, há também um viés que pode elevar o preço do frete, fruto do reduzido grau de competitividade intermodal no país, advindo da peculiaridade da prestação de serviços porta-à-porta desenvolvida pelo modal rodoviário, e principalmente devido ao sub-aproveitamento do potencial de modais alternativos como o ferroviário e o hidroviário, o que colabora para a redução da concorrência entre os modais. 
Tais variáveis, de maneira isolada ou conjunta, são consideradas e comentadas por diversos autores, conforme sumarizado a seguir.

\section{- Distância percorrida}

A maioria dos trabalhos que aborda a estrutura dos fretes praticados considera a distância como principal fator de determinação de valores, independentemente do modal utilizado.

Binkley \& Harrer (1981) ressaltam que o método linear, ao contrário da forma logarítmica, é mais adequado para estimar valores de fretes marítimos para transporte de grãos, pois permite a separação dos custos fixos e variáveis, uma vez que os custos fixos, entendidos como os custos portuários, afetam o frete de maneira aditiva e não multiplicativa.

Beilock et al. (1996) argumentam que, de modo geral, estudos que procuram identificar os determinantes dos fretes rodoviários são primeiramente dependentes da distância e ajustados por outros fatores.

Oliveira (1996) identifica uma estreita relação entre a distância percorrida e o valor do frete praticado para o transporte rodoviário de soja, milho e farelo de soja na área de influência da hidrovia Tietê-Paraná.

Martins (1998), através da estimação de uma função linear de frete, também encontra uma relação bastante satisfatória entre a distância percorrida e o preço do frete rodoviário para o transporte de milho, soja, farelo de soja e trigo para rotas selecionadas no estado do Paraná.

\section{- Custos operacionais}

Autores como Hauser (1986), Hsu \& Goodwin (1995), Allen \& Liu (1995) e Miljkovic et al. (2000) consideram os custos operacionais como uma variável exógena em trabalhos de pesquisa que buscam estudar a formação dos valores de frete. 
Os custos operacionais podem influenciar o preço do frete praticado em diferentes rotas de maneira distinta. Ocorre, porém, que as diferenças regionais de interação entre a demanda e oferta de serviços de transporte podem impedir que o impacto da elevação de custos operacionais sobre os valores dos fretes seja direto e homogêneo em todas as regiões.

Assim, a evolução dos preços dos componentes de uma planilha de custos de transportes pode pressionar, de maneiras distintas, reajustes nos preços praticados de frete.

\section{- Possibilidade de carga de retorno}

O transporte de cargas com destino aos portos e às regiões mais desenvolvidas, como os estados do Sudeste e Sul do Brasil, pode representar fretes menores devido à possibilidade do transporte de carga de retorno para suas zonas de origem.

Para Beilock et al. (1986), o valor do frete praticado não é somente função dos custos derivados da prestação do serviço de transporte, mas também devido a outros fatores, como as condições de oferta de transporte na origem e possibilidade de carga de retorno no destino. Assim, os fretes tendem a ser menores quanto maior for a possibilidade de se conseguir carga de retorno e mais elevado quando a oferta de serviços de transporte for escassa na origem e o tempo de espera para obtenção de carga de retorno se tornar prolongado.

De modo inverso, fluxos que não proporcionam o transporte de carga de retorno podem representar valores de frete mais elevados. A revista Crossborner Monitor (1997) ressalta que, no Brasil, além das más condições das vias, a concentração das indústrias no Sudeste do país é um dos principais fatores que elevam os custos logísticos por criar um fluxo de distribuição de mão única.

Prentice \& Benell (1992) indicaram que o Canadá poderia elevar suas exportações de alimentos para os Estados Unidos explorando fretes menores associados à carga de retorno, utilizando-se da frota de caminhões refrigerados americanos que, 
após transportar vegetais e frutas frescas, normalmente voltavam vazios para o país de origem.

\section{- Carga e descarga}

Beilock et al. (1986) salientam que os transportadores tendem a aceitar fretes mais baixos quanto menor for o tempo de espera. Segundo Caixeta Filho et al. (1998b), o custo de oportunidade relacionado ao tempo de carga é observado, por exemplo, no primeiro percurso da produção de soja, quando a colheita é acondicionada nos próprios caminhões devido à inexistência de locais para armazenamento nas zonas produtivas, o que implica um período de espera relativamente longo por parte dos motoristas, elevando custos. Essa característica acarreta uma maior demanda por transporte na época de safra, pressionando os preços dos fretes, fenômeno que não ocorre em outros países, como os Estados Unidos, onde a maioria das propriedades possui áreas de armazenamento.

\section{- Sazonalidade da demanda por transporte}

A sazonalidade da demanda por transporte está intimamente relacionada à incapacidade de armazenamento da produção nas unidades produtoras. De acordo com Caixeta Filho et al. (1998b), essa sazonalidade é decorrente dos períodos de safra e entressafra, principalmente para produtos como açúcar, soja e milho em grãos.

De acordo com Soares et al. (1997), a safra da soja é o fator que traz maiores impactos sobre o mercado de transporte rodoviário de cargas, destacando que, devido à baixa capacidade de estocagem das cooperativas e outras empresas, a maior demanda ocorre em trechos que partem das unidades produtoras.

Outro aspecto que merece atenção é o volume de grãos produzidos anualmente que, de acordo com sua distribuição geográfica, pode afetar o valor do frete rodoviário em diferentes rotas. 
Siqueira \& Oliveira (2000) argumentam que os baixos volumes de arroz, milho e soja produzidos no Mato Grosso do Sul, Paraná e Rio Grande do Sul, durante a safra de 2000 , reduziram a demanda por transporte, afetando o preço do frete não somente nessas regiões, mas também em outros estados, uma vez que transportadores de outros estados seguem para essas regiões em época de colheita em busca de fretes melhores, mesmo tendo que utilizar estradas malconservadas.

\section{- Especificidade da carga transportada e do veículo utilizado}

Caixeta Filho et al. (1998b) ressaltam a prática de preços distintos e de condições especiais para o transporte de alguns tipos de cargas como, por exemplo, o estabelecimento de condições para o transporte em comboio para a locomoção de cargas com maior valor de mercado devido à possibilidade de roubos e assaltos.

Ortúzar (1990) indica que o tipo de carga pode influenciar o preço do frete. Neste mesmo sentido, a embalagem do produto transportado também pode ser um diferencial. Segundo Caixeta Filho et al. (1998b), o transporte de grãos ensacados, como a soja (farelo e grãos) e o milho em grãos, não exige grande especificidade de transporte e, portanto, pode se utilizar de uma gama mais diversificada de equipamentos de transporte, implicando contratos contingenciais e, de modo geral, informais. Diferentemente, em mercados com características mais específicas, como o transporte de suco de laranja e leite, imperam maiores formalidades contratuais devido a essa maior especificidade.

\section{- Perdas e avarias}

Ross (1999) comenta sobre estimativas do Banco Mundial que indicam que são perdidos US $\$ 500$ bilhões com acidentes rodoviários no mundo, sendo que os países em desenvolvimento são responsáveis por uma perda de cerca de US\$ 100 bilhões. No Brasil, em 1994, de acordo com Departamento Nacional de Estrada de Rodagem (2001), 
as perdas econômicas decorrentes de acidentes rodoviários, ano em que foram registrados 77.986 acidentes, foram estimadas em mais de US\$ 1 bilhão.

Já em 1998, segundo o Anuário Estatístico de Transportes 2000 (2000), foram registrados 120.442 acidentes rodoviários no país envolvendo tanto passageiros quanto cargas. Sozinho, o estado de Minas Gerais foi responsável por 19,07\% dos acidentes, seguido por São Paulo (10,59\%), Rio de Janeiro (10,14\%), Rio Grande do Sul $(9,55 \%)$ e Santa Catarina $(9,52 \%)$. Juntos, os cinco estados foram responsáveis por $58,87 \%$ dos acidentes ocorridos nas estradas brasileiras durante o ano de 1998, o que traz evidências sobre a concentração do fluxo de veículos nas regiões Sul e Sudeste.

Outra fonte de perdas, como danos ocasionados devido à exposição à chuva, também pode ser observada. Assim, o seguro de transporte assume um importante papel, sendo que diante de tantas perdas potenciais, o prêmio com seguro passa a apresentar valores elevados, o que, segundo o Banco Mundial (1997), pode implicar impacto significativo sobre o preço do frete a ser praticado.

\section{- Vias utilizadas}

As condições das vias utilizadas podem influenciar o preço do frete. A má conservação das vias pode elevar os custos de manutenção dos veículos, tornando a atividade de transporte mais lenta, além de causar maior exposição a acidentes.

Minten \& Kyle (1999) atribuem parte da dispersão de preços de produtos agrícolas, em diferentes regiões produtoras no Zaire, aos custos de transporte, admitindo que a qualidade das rodovias tem grande influência sobre esses valores. De acordo com os autores, vias mal conservadas elevam significativamente os custos de transporte, o risco e outros custos de transação.

De acordo com a Pesquisa Rodoviária conduzida pela Confederação Nacional do Transporte (2000), em 1999, que avaliou 38.188 quilômetros de rodovias, o equivalente a mais de $70 \%$ das estradas federais e 4.627 quilômetros de estradas estaduais, 77,5\% das vias foram classificadas como péssimas ou deficientes. 
Vale destacar que a pesquisa revelou que os piores trechos encontrados estavam localizados nas regiões Norte, Nordeste e Centro-Oeste, e principalmente no Nordeste. Por outro lado, as dez rodovias federais consideradas em melhor estado de conservação pertenciam às regiões Sul e Sudeste.

\section{- Pedágios e fiscalização}

As regras mais rígidas implementadas pelo novo Código de Trânsito Brasileiro pela Lei $n^{\circ}$ 9.503, em 1997, além da elevação do número de praças de pedágio e postos de fiscalização, frutos da reestruturação rodoviária promovida pelo Estado, principalmente a partir de 1994, são razões de reclamações por parte dos motoristas e caminhoneiros, podendo portanto influenciar os valores de frete praticados.

Nesse sentido, a reportagem ASSEMBLÉIA no RS ... (2000), destaca que a paralisação promovida pelo Movimento União Brasil Caminhoneiro, durante a primeira semana de maio de 2000 , obrigou o governo federal a negociar a criação de um valepedágio, em decorrência da exigência dos grevistas para redução do preço dos pedágios, transferindo o pagamento do pedágio para os donos da carga.

\section{- Prazo de entrega}

O transporte eficiente deve ser capaz de respeitar prazos de entrega, com o objetivo de reduzir custos logísticos. Produtos que são entregues antes ou após a data programada podem implicar elevação dos custos devido à necessidade de armazenamento e à redefinição da programação de produção das empresas.

\section{- Aspectos geográficos}

Segundo Caixeta Filho et al. (1998b), as características dos trechos percorridos podem influenciar os valores dos fretes de forma que trechos muito movimentados 
apresentam valores inferiores àqueles pouco utilizados. Já para Ortúzar (1990), a densidade populacional pode influenciar a distribuição e o destino de produtos.

\subsection{Caminhões, caminhoneiros e outras características da oferta de transporte}

A importância do setor de transporte para a economia mundial pode ser largamente comprovada. De acordo com o World Bank Group (2000), estima-se que o setor emprega de $5 \%$ a $8 \%$ da mão-de-obra ativa no mundo, sendo responsável por algo em torno de $3 \%$ a $5 \%$ do Produto Nacional Bruto mundial.

A evolução da frota de veículos pesados dentro da matriz de transporte nacional pode ser comprovada pela expansão do consumo de óleo diesel no país nos últimos anos. De acordo com a Agência Nacional de Petróleo (2001), foram consumidos 33,8 milhões de litros de óleo diesel em 1998, com um crescimento médio de 5,5\% nos últimos cinco anos.

Apesar desse montante agregar o consumo industrial $(5 \%)$ e a parcela destinada à geração de energia elétrica (5\%), constata-se que $61 \%$ do total foi destinado a postos de revenda, o que valida a análise.

A Figura 2 mostra mais detalhadamente a evolução do consumo de óleo diesel no Brasil, onde pode-se observar a dinâmica expansionista do setor, passando de ínfimos 202 mil litros, em 1947, para 17,8 milhões, em 1981, após o "milagre econômico" observado durante a década de setenta, evoluindo para 29,1 milhões de litros em 1989, volume que só foi superado a partir de 1996 (30,1 milhões de litros).

Como o setor de transporte de cargas rodoviárias utiliza o óleo diesel como fonte de energia no desenvolvimento da atividade, as estratégias políticas para o setor energético, especialmente aquelas relacionadas à indústria do petróleo, podem impactar diretamente os preços do frete. Segundo a revista American Shipper (2000), a elevação nos preços dos derivados de petróleo devido ao controle da oferta por parte da Organização dos Países Exportadores de Petróleo - OPEP, em 1999, levou o Congresso americano, por exemplo, a estudar maneiras para reduzir o preço do diesel através, por exemplo, da eliminação temporária de um imposto federal de US\$ 0,24 por galão de 
óleo diesel, devido à pressão por parte dos transportadores e também em decorrência do temor de maiores impactos sobre a economia.

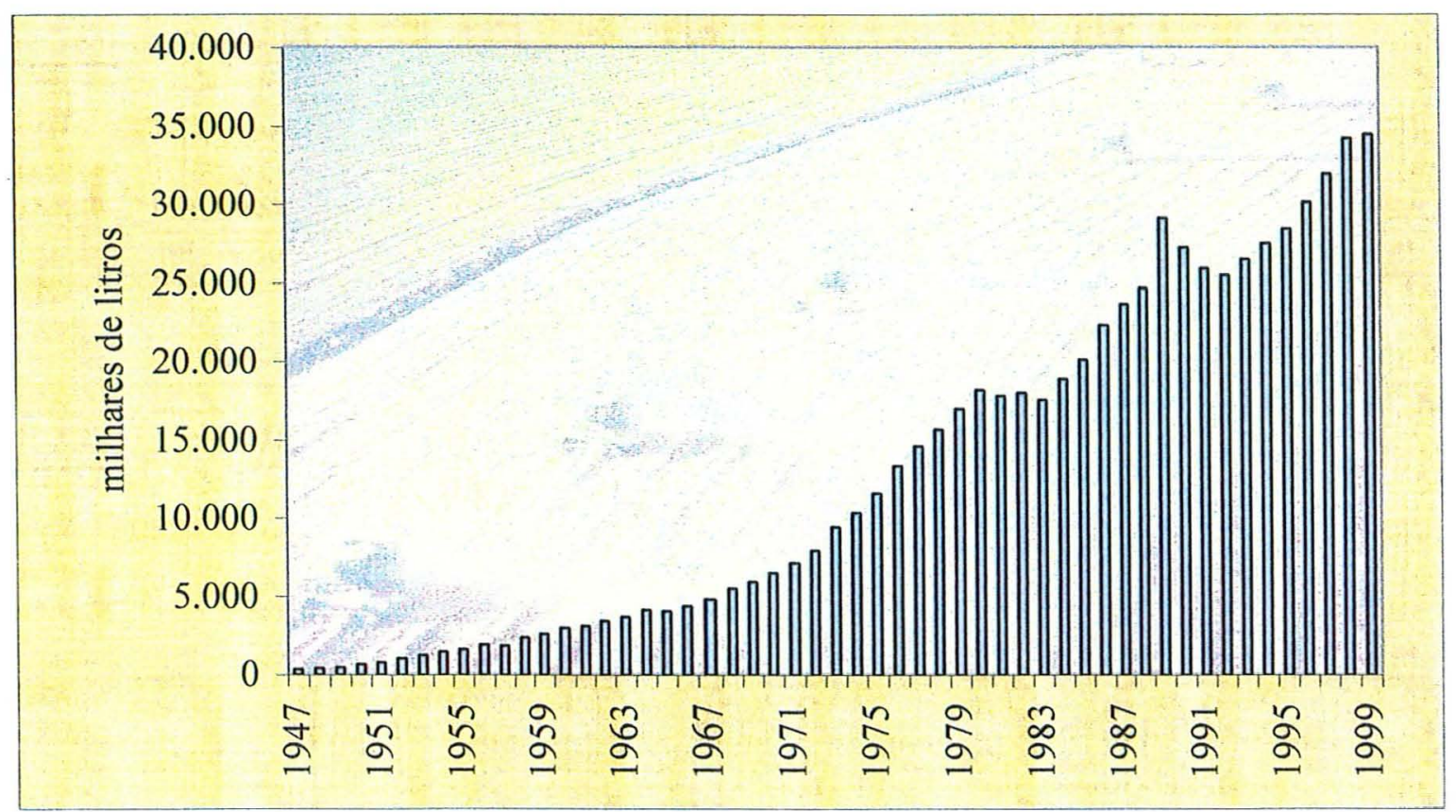

Figura 2 - Consumo anual de óleo diesel no Brasil entre 1947 e 1999 em milhares de litros.

Fonte: Agência Nacional de Petróleo (2001)

A frota nacional de veículos comerciais destinados ao transporte de cargas em 1998, no Brasil, somava 1.755.877 unidades, ou seja, cerca de 5,7\% da frota nacional de veículos automotores, que é de 30.667 .710 unidades. De acordo com o Anuário Estatístico de Transportes 2000 (2000), vale destacar o alto grau de depreciação da frota, sendo mais de $70 \%$ da mesma composta por veículos com mais de dez anos.

De acordo com Caixeta Filho et al. (1998b), para a realização do transporte de cargas agrícolas são utilizados, principalmente, caminhões de grande porte. Considera-se como veículo padrão as chamadas "carretas", com capacidade para até 27 toneladas. Esses veículos são constituídos de cavalos mecânicos com motor de no mínimo $360 \mathrm{CV}$, apoiados por semi-reboques de três eixos e caçamba de metal basculante (graneleiras), ou de madeira, aberta, com laterais baixas, para transporte de sacarias, ou altas, para transporte de granéis. 
Mais recentemente, porém, em decorrência de um ambiente cada vez mais competitivo, transportadores mais capitalizados têm optado por uma nova modalidade, denominada bi-trem, que permite o transporte adicional de 10 toneladas através da utilização de duas carretas ao invés de um única, reduzindo custos. Segundo Siqueira \& Oliveira (2000), entre $40 \%$ e $50 \%$ dos veículos que prestam serviço de transporte de grãos nos estados de Mato Grosso e Mato Grosso do Sul são do tipo bi-trem. Os autores atribuem boa parte das vendas de veículos pesados, nos primeiros meses do ano 2000 , à evolução dessa modalidade de transporte no país.

Como característica inerente a essa opção de modal de transporte, surge a figura dos caminhoneiros autônomos e motoristas ligados às empresas que atuam no setor como os principais agentes responsáveis pela dinâmica da atividade. Segundo o Banco Mundial (1997), em 1996, os caminhões pertencentes aos caminhoneiros autônomos eram normalmente de tamanho médio, de carrocerias abertas e mais depreciados, atuando principalmente no transporte de médias e longas distâncias.

De acordo com pesquisa elaborada pela Confederação Nacional do Transporte (1999a), os caminhoneiros alegam que os custos de manutenção, pedágio, deterioração das rodovias, gastos familiares e a política do Estado para o setor são os principais fatores que dificultam a sustentabilidade da atividade da categoria, juntamente com a pressão da mão-de-obra advinda de outras áreas, devido às altas taxas de desemprego no país.

Também de acordo com a Confederação Nacional do Transporte (1999a), os motoristas autônomos rodam, em média, $100.000 \mathrm{~km} / \mathrm{ano}$, e apesar de obterem renda bruta mensal de $\mathrm{R} \$ 3.000,00$, o desenvolvimento da atividade incorre em altos custos. Somente o pedágio é responsável por uma despesa média mensal de $\mathrm{R} \$ 400,00$. Ainda, apesar da renda mensal líquida ser de $\mathrm{R} \$ 1.200,00$, os caminhoneiros pagam em média $\mathrm{R} \$ 500,00$ com manutenção de moradia, sendo que $24,5 \%$ dos entrevistados pagam prestação mensal de aquisição de veículo no valor de $\mathrm{R} \$ 1.100,00$, o que mostra a vulnerabilidade da categoria. Por outro lado, o salário dos motoristas ligados às empresas é de $\mathrm{R} \$ 700,00$. 
A pesquisa realizada pela Confederação Nacional do Transporte (1999a), realizada com uma amostra composta por 1.000 motoristas e caminhoneiros autônomos de todo Brasil, revelou que dos 600 caminhoneiros autônomos entrevistados, 77,2\% abrangem áreas interestaduais, sendo que $64,8 \%$ possuem veículos próprios, quitados; $22 \%$, financiados; $4,5 \%$, em leasing e $6,9 \%$ possuem mais de um caminhão.

A categoria é quase que totalmente formada por homens, com grau de escolaridade média de 8 anos de estudo, com núcleos familiares de quatro pessoas em média. $\mathrm{O}$ medo de assaltos, acidentes e a má conservação das estradas lideram as preocupações da categoria. Cerca de $6,2 \%$ dos entrevistados sofreram assalto anteriormente. A pesquisa revelou ainda que 18,5\% dos autônomos e 16,9\% dos motoristas alegaram a ocorrência de stress durante o ano de 1998 em decorrência do exercício da atividade.

\subsection{A relação entre os fatores que podem identificar os preços dos fretes e os custos operacionais de transporte}

É importante destacar que os custos relacionados com a atividade de transporte são de difícil mensuração, uma vez que o consumo de determinados itens depende de algumas condições de transporte e do próprio desempenho do transportador.

Fatores que compõem a pauta de custos, como os gastos com combustível, lubrificantes e pneus, por exemplo, são fáceis de serem identificados e quantificados, fazendo com que os transportadores tenham uma maior facilidade de estar repassando eventuais aumentos dos preços desses insumos aos valores do frete.

Ocorre, porém, que o consumo desses insumos pode variar de acordo com o tipo de estrada utilizada, geografia das estradas (percursos mais íngremes), temperatura etc., sendo que a influência desses fatores sobre os custos totais muitas vezes é difícil de ser identificada, o que dificulta a internalização desses efeitos nos preços dos fretes.

Tem-se observado no Brasil, nos últimos tempos, um descontentamento generalizado por parte dos transportadores quanto aos preços recebidos pelos fretes rodoviários praticados. Parte desse descontentamento pode ser explicado pelo 
descompasso da evolução dos custos operacionais em relação ao preço do frete praticado, o que tem um impacto direto sobre as margens de lucro na atividade.

Minahan (1996) argumenta que a baixa demanda por frete, o baixo aproveitamento dos equipamentos, assim como a elevação de custos, foram os responsáveis pela baixa lucratividade do frete rodoviário nos Estados Unidos em meados de 1995. Dentre os itens de custos, o autor destaca o preço do óleo diesel como um dos principais responsáveis por esse fenômeno.

Além dos gastos com diesel e salários, Labbe (1999) destaca que o gasto com manutenção é outro fator que se destaca dentro da estrutura de custos.

Castro (1988) argumenta que, considerando a carga tributária, a estrutura de custos representa cerca de $94 \%$ das receitas operacionais da atividade de transportes no Brasil, o que evidencia que o setor opera com margens reduzidas.

Labbe (1999) destaca que alguns custos não devem ser rateados linearmente. Gastos com seguros, por exemplo, não devem ser necessariamente rateados por distância percorrida, devendo ser considerados outros fatores, como valor da carga transportada.

Os gastos com manutenção podem variar conforme sua gestão. A utilização de pneus corretos e de qualidade pode trazer melhor desempenho e retorno do investimento em pneus. Birkland (1996) comenta que transportadores que tratam a troca de pneus como um componente secundário tendem a utilizar pneus com menos borracha, o que reduz o retorno desse investimento devido à baixa vida útil dos pneus e à maior exposição a acidentes.

Kerkvliet \& McMullen (1997) examinaram as diferenças de custos entre empresas de transporte sindicalizadas e não sindicalizadas nos Estados Unidos, através de uma função de custo translog, utilizando uma estrutura de produção que considerava as seguintes variáveis:

- densidade de transporte (quantidade/distância) observada;

- tamanho médio da carga transportada;

- distância média do frete;

- seguro, em função da distância percorrida; 
- tamanho médio do carregamento no equipamento de transporte;

- nível monetário do passivo;

- preço do combustível;

- nível monetário de capital próprio;

- nível de salários.

Eakin et al. (1990) ${ }^{3}$, citados por Kerkvliet \& McMullen (1997), indicam uma diferença estatística significativa entre as estruturas de custos de transportadoras sindicalizadas e não sindicalizadas nos Estados Unidos. Empresas não sindicalizadas apresentam maiores economias associadas com o tamanho da carga e tamanho médio do veículo, dois importantes determinantes de custos.

Além dos custos diretos relacionados na estrutura de custos, a atividade de transporte causa inúmeras externalidades. Forkenbrock (1999) estima que externalidades geradas pela atividade do transporte rodoviário de cargas entre as cidades americanas, tais como acidentes rodoviários, barulho, poluição do ar e subsídios, representam cerca de $13,2 \%$ dos custos privados da atividade de transporte.

Conclui-se, portanto, que a complexidade de mensuração da influência de alguns fatores sobre os custos totais de transporte pode contribuir para que os transportadores tenham apenas uma percepção superficial da maneira com que alguns desses fatores influenciam os custos da atividade, levando-os a considerá-los na composição dos preços dos fretes apenas em situações específicas como, por exemplo, durante as safras, pois nesse período os transportadores estão mais confortáveis para expressar suas preferências por determinados percursos em função da elevação da demanda pelos seus serviços.

${ }^{3}$ EAKIN, B.; MCMILLEN, D.; BRUNO,M. Constructing Confidence Intervals Using the Bootstrap: An Application to a Multiproduct Cost Function. Review of Economics and Statistics, May 1990. 


\section{MATERIAL E MÉTODOS}

Frente aos objetivos propostos para o desenvolvimento do trabalho de pesquisa, pretende-se utilizar, como objeto de estudo, o transporte rodoviário de soja entre diferentes regiões brasileiras, valendo-se para tanto das rotas mais representativas, ou melhor, daquelas que representam o maior fluxo de escoamento da produção agrícola.

Seguindo a estrutura adotada por Buckley \& Westbrook (1991), a demanda por transporte pode ser especificada pela data, produto, origem e destino como, por exemplo, "soja (granel) com origem na cidade de Rio Verde (Goiás) e destino em Uberaba (Minas Gerais), via rodoviária, em março de 1999".

Uma vez definido o mercado, a relação entre a demanda e oferta de transporte para aquele mercado específico determina o preço de frete a ser praticado.

Genericamente, os pontos de origem da atividade de transporte rodoviário de soja são as unidades produtoras, com destino às indústrias ou portos. $\mathrm{O}$ fato gerador da demanda de transporte é a necessidade de movimentação da mercadoria. Os demandantes dos serviços de transportes, em geral, são os donos da carga, conhecidos como embarcadores, que podem ser os responsáveis pelo pagamento efetivo do frete e, conseqüentemente, pela interface com os transportadores.

Assim sendo, a carga pode pertencer ao produtor, que movimenta a produção até pontos específicos para só então realizar a efetiva comercialização de seu produto; pode pertencer à indústria, que compra diretamente das unidades produtoras como insumo para o seu processo de produção; ou então pertencer a traders, elementos de intermediação na comercialização. 
Segundo Ortúzar (1990), vários aspectos podem influenciar a demanda por transportes. Fatores operacionais como o tamanho da firma, a política de distribuição e a sua localização geográfica podem ter forte influência sobre os modais alternativos que a empresa demandante pode se valer, assim como sobre suas estratégias de transporte.

A Tabela 4 mostra algumas diferenças observadas nos preços dos fretes para transporte de soja em grãos, para percursos com distâncias e origem/destino distintos, não sendo difícil notar a diferença de preços praticados em percursos com diferentes extensões. O frete de Batatais (SP) com destino a Monte Alto (SP), por exemplo, apresentou um valor de cerca de $\mathrm{R} \$ 0,1171$ por tonelada-quilômetro (t.km) percorrido, em março de 2000, em um percurso de cerca de 111 quilômetros. Já percursos como de Chapadão do Baús (MS) para Ourinhos (SP), com 860 quilômetros de extensão, apresentaram um valor menor, cerca de $\mathrm{R} \$ 0,0488$ t.km, aproximadamente $46 \%$ do valor observado para o percurso anterior, para o mesmo período, o que evidencia que, de modo geral, percursos mais longos apresentam fretes unitários relativamente menores ( $\mathrm{R} \$ / \mathrm{t} . \mathrm{km})$, ao permitir que os custos fixos sejam diluídos.

Tabela 4. Preço do frete para transporte rodoviário de soja em grãos, em março de 2000.

\begin{tabular}{ccccc}
\hline Origem & Destino & $\begin{array}{c}\text { Distância } \\
(\mathrm{Km})\end{array}$ & $\begin{array}{c}\text { Frete } \\
(\mathrm{R} \$ / \mathrm{t})\end{array}$ & $\begin{array}{c}\text { Frete } \\
\mathrm{R} \$ / \text { t.km }\end{array}$ \\
\hline Batatais (SP) & Monte Alto (SP) & 111 & 13,00 & 0,1171 \\
Chapadão do Baús (MS) & Ourinhos (SP) & 860 & 42,00 & 0,0488 \\
Coronel Vivida (PR) & Paranaguá (PR) & 477 & 26,40 & 0,0553 \\
Chapadão do Céu (GO) & Santos (SP) & 1043 & 53,33 & 0,0511 \\
Dourados (MS) & Santos (SP) & 1017 & 47,33 & 0,0465 \\
Dourados (MS) & Paranaguá (PR) & 967 & 51,50 & 0,0533 \\
Lucas do Rio Verde (MT) & Rondonópolis (MT) & 534 & 25,00 & 0,0468 \\
Mamboré (PR) & Paranaguá (PR) & 542 & 27,50 & 0,0507 \\
\hline
\end{tabular}

Fonte: SIFRECA (2000)

Por outro lado, em percursos com extensões parecidas e mesmo destino, como é o caso das rotas de Chapadão do Céu (GO) para Santos (SP) e de Dourados (MS) para Santos (SP), ambas com aproximadamente mil quilômetros de extensão, observou-se 
que o preço do frete praticado apresenta valores diferentes, $R \$ 0,0511$ e $R \$ 0,0465 / \mathrm{t} . \mathrm{km}$, respectivamente, evidenciando que existem outras variáveis que influenciam o estabelecimento do preço dos fretes, além da própria distância.

O mesmo fenômeno também pode ser observado em percursos com a mesma origem, mas com destinos em estados diferentes. A soja transportada de Dourados (MS) com destino ao porto de Santos, em São Paulo, representa um frete equivalente a R\$ 0,0465/t.km; porém, se o destino for o porto de Paranaguá, no estado do Paraná, esse valor eleva-se para $R \$ 0,0533 / \mathrm{t} . \mathrm{km}$, mesmo que as distâncias sejam equivalentes, 1.017 $\mathrm{km} \mathrm{e} 967 \mathrm{~km}$, respectivamente.

De acordo com Caixeta Filho et al. (1998b), as características de negociação do preço do frete agrícola representam um dos principais componentes para determinação do preço contratado, sendo que, de modo geral, os demandantes têm escala suficiente para exercer um maior poder de barganha frente à elevada e pulverizada oferta de serviços de transporte disponíveis.

Como observam os autores, os contratos formais para contratação de frete para transporte de soja e milho são raros, principalmente devido à baixa especificidade exigida dos veículos, o que eleva os custos de transação ao permitir que autônomos atuem ativamente no mercado, competindo com empresas transportadoras, acarretando o desenvolvimento de uma estrutura contratual informal bastante confusa.

Para Caixeta Filho et al. (1998b), mesmo havendo reajustes nos componentes operacionais dos serviços de transporte, como o óleo diesel, por exemplo, a existência de uma estrutura de oferta de serviços cada vez mais competitiva não tem permitido que sejam efetuados reajustes freqüentes nos valores dos fretes nos últimos tempos, sendo que os possíveis ganhos da categoria têm se baseado principalmente em uma maior produtividade dos transportadores. Em contrapartida, em mercados com características mais especificas, envolvendo, por exemplo, poucos e grandes compradores, o comportamento da frota tende a ser mais estável.

Para ilustrar essa situação, é apresentada a Figura 3, mostrando a evolução dos preços mensais médios dos fretes amostrados de soja a granel, de Marcianópolis (GO) com destino a Itumbiara (GO), em um percurso equivalente a 116 quilômetros, entre 
outubro de 1997 e maio de 2000. Vale destacar que por falta de dados, o valor referente a abril de 1998 é uma média dos valores médios dos meses de março e maio de 1998 e o valor referente a janeiro de 2000 é uma média dos valores médios dos meses de dezembro e fevereiro de 2000.

Como pode ser observado na Figura 3, mesmo que tenha havido uma elevação nos custos operacionais de transporte durante o período amostrado, as características do mercado impediram um realinhamento dos valores praticados. Assim, mesmo que tenham sido observados preços elevados, durante o período de junho de 1998 a outubro de 1998, esses valores não foram mais recuperados até o final do período analisado (maio de 2000).

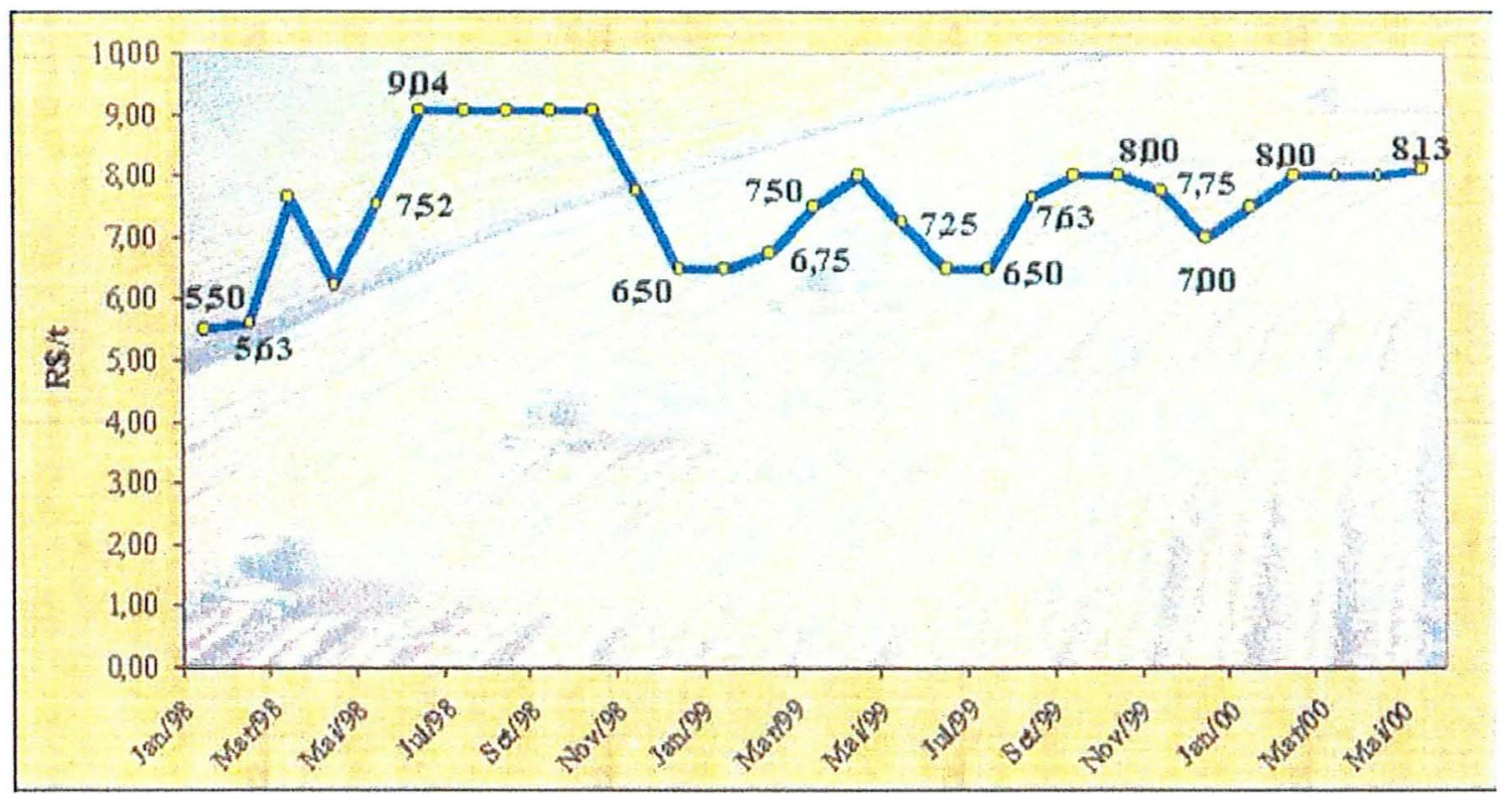

Figura 3 - Média mensal real dos preços do frete de soja a granel, em $R \$ / t$, de Marcianópolis (GO) com destino a Itumbiara (GO), entre janeiro de 1998 e maio de 2000.

Fonte: SIFRECA

Vale salientar que, Como destacam Caixeta Filho et al. (1998b), a sazonalidade da demanda por transporte, entre outros fatores, também pode influenciar na negociação do preço do frete. O período de escoamento da produção da soja, por exemplo, entre os meses de março e junho, inflaciona o preço dos fretes, principalmente porque coincide 
com o período de escoamento da produção de milho e açúcar, que são transportados por veículos de baixa especificidade.

A Figura 4 ilustra os valores de frete de soja praticados em um percurso de 1.249 quilômetros, entre Jataí (GO) e Paranaguá (PR), onde pode ser observada uma maior variabilidade de preços.

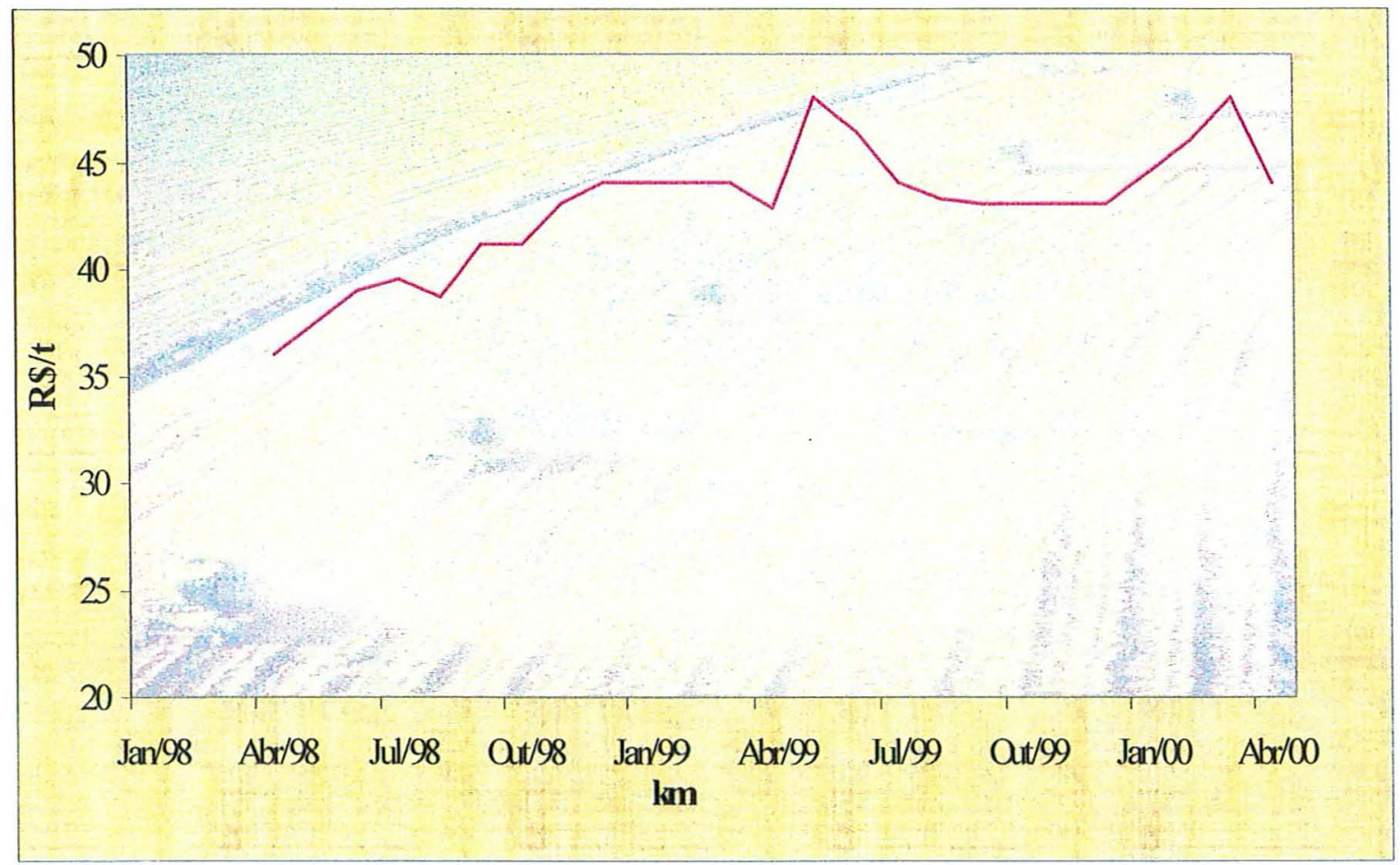

Figura 4 - Média mensal real dos preços do frete de soja a granel, em $\mathrm{R} \$ / \mathrm{t}$, de Jataí (GO) com destino a Paranaguá (PR), entre janeiro de 1998 e maio de 2000. Fonte: SIFRECA

Devido à complexidade na formação do preço do frete rodoviário de grãos e à dispersão dos valores observados, provavelmente o valor econômico do frete praticado não esteja alinhado com o valor real desse serviço.

\subsection{Abordagens econométricas alternativas}

De acordo com Hauser (1986), a modelagem matemática vem sendo largamente utilizada em estudos que abordam a questão dos transportes, inclusive no tratamento das 
tarifas de transporte. Particularmente, com relação a análises econométricas, estas têm sido utilizadas para identificar os principais fatores que influenciam os valores de fretes para produtos diversos, assim como para estimar a função de demanda por transporte.

A literatura especializada documenta uma série de aplicações de modelos econométricos a problemas relacionados com a determinação do preço do transporte de cargas.

Para Thompson (1960), por exemplo, a determinação do valor do frete de produtos químicos, nos Estados Unidos, estava diretamente relacionada à distância percorrida. $\mathrm{O}$ trabalho desenvolvido pelo autor utilizou uma forma geral, reproduzida pela equação (1):

$$
F=u M^{x}+c
$$

onde:

$F=$ valor do frete por unidade transportada;

$M=$ distância em milhas;

$c, u, x=$ coeficientes.

Thompson (1960) ressalta que o expoente de $M$ determina a relação entre o frete praticado e a distância percorrida, sendo que em alguns casos especiais essa relação pode ser linear $(x=1)$; porém, na maioria dos casos, segundo o autor, $x$ é menor que 1 , ou seja, a relação entre as duas variáveis é não-linear.

O coeficiente $u$, por sua vez, pode ser entendido como um custo variável associado a cada milha percorrida, enquanto $c$ eqüivale aos custos fixos totais, independentes da distância percorrida.

Para a modelagem de relações não-lineares, o mesmo autor destaca a forma logarítmica log-log, tal como ilustrado pela equação (2): 
$\log (F-c)=x \log M+\log u$

Caso $c=0$, a equação (2) passa a ser aproximada a uma reta, só apresentando alguma curvatura quando $\mathrm{c} \neq 0$.

Kerr (1972) utiliza a análise de mínimos quadrados, através de técnicas de regressão múltipla, para estudar o comportamento do frete ferroviário de produtos com características distintas nos Estados Unidos, valendo-se do modelo geral representado pela equação (3).

$y=\mathrm{a}_{0}+\mathrm{a}_{1} w+b w m$

onde:

$y=$ frete praticado;

$a_{0}=$ frete base;

$w=$ peso da carga em toneladas;

$a_{l}=$ taxa de transbordo por tonelada;

$m=$ milhas percorridas;

$b=$ frete em $\mathrm{t} / \mathrm{milha}$.

sendo que $a_{l}$ e $b$ variam de acordo com o tipo de bem transportado.

Os autores salientam que, admitindo que os custos de transbordo e frete/milha são menores para grandes quantidades transportadas, poderiam ser incluídos os termos quadráticos $a_{2} w^{2}$ e $b_{2}(w m)^{2}$.

Miklius et al. (1976), abordando a elasticidade de serviços de transporte para o transporte de cerejas e maçãs nos Estados Unidos, estimam a elasticidade da demanda e a elasticidade cruzada, em relação ao preço e quantidade de frete, para dois modais alternativos (rodoviário ou ferroviário), através de um modelo lógite, considerando o tempo de transporte como uma variável que pode influenciar o valor do frete praticado, 
visto que esses produtos se degradam em um ritmo diferente. O modelo especificado pelos autores é identificado pela forma funcional apresentada pela equação (4).

$\log \{p /(1-p)]=\alpha+\beta_{1 i} C_{i}-\beta_{1 j} C_{j}+\beta_{2 i} C_{i}-\beta_{2 j} C_{j}+\beta_{3 i} V T_{i}-\beta_{3 j} V T_{j}+\sum_{k=I}^{t}{ }_{k} S_{k}$

onde:

$p=$ probabilidade de escolha de determinado modal;

$C_{i}$ e $C_{j}=$ frete demandado para os modais $i$ e $j$;

$T_{i}$ e $T_{j}=$ tempo de trânsito para os modais $i \mathrm{e} j$;

$V T_{i}, V T_{j}=$ variância do tempo de trânsito;

$\alpha, \beta_{l i}, \beta_{i j}, \beta_{2 i}, \beta_{2 j}, \beta_{3 i}, \beta_{3 j}, \gamma_{k}=$ coeficientes;

$s_{k}=k$-ésima característica relevante para a escolha do modal de transporte utilizado (preço da commodity, tempo de validade do produto etc.).

Entre os resultados encontrados, os autores concluem que culturas mais perecíveis, tais como cerejas, demandam vias de transporte mais rápidas, ficando sujeitas a um preço de transporte diferenciado.

Binkley \& Harrer (1981), através de dois modelos lineares, estimados por mínimos quadrados ordinários (ordinary least squares - OLS), analisam os determinantes do preço do frete marítimo de grãos, utilizando a especificação ilustrada na equação (5).

$R A T E=f(D I S T, S I Z E, T E R M S, Q U A R T, F L A G, V O L, P O R T)$

onde:

$R A T E=$ preço do frete (dólares por tonelada); 
$D I S T=$ distância entre origem e destino;

$S I Z E=$ tamanho da embarcação;

TERMS = custos de transbordo;

$Q U A R T=$ quadrimestre do embarque;

$F L A G=$ bandeira do navio;

$V O L=$ volume transportado;

$P O R T=$ portos de origem/destino.

O primeiro modelo utilizado pelos autores procurou examinar o efeito médio das variáveis consideradas sobre o valor do frete. Para tanto, os autores utilizaram como variáveis independentes a distância e a distância ao quadrado, o tamanho do navio e o tamanho do navio ao quadrado, o volume transportado e variáveis binárias para o trimestre do embarque, tipos de contrato de transporte ("free discharge" e "gross terms") e uma variável binária para os navios de bandeira americana que, de acordo com o trabalho, têm comportamento diferenciado dos demais.

O segundo modelo, mais complexo, é um modelo de covariância, que permite examinar a hipótese de que a economia de escala varia de acordo com o tamanho da embarcação. A diferença para o primeiro modelo reside na substituição das variáveis tamanho do navio e tamanho do navio ao quadrado por seis classes diferentes de tamanho, adicionando dois grupos de variáveis de interação com as classes de tamanho: um, relacionando-as com os dois modelos de contrato de transporte; e outro, com a distância e a distância ao quadrado. Consideraram ainda variáveis binárias para cada par de origem e destino.

Os autores destacam que rotas com maior fluxo de cargas apresentam normalmente frete menor, devido à possibilidade de obtenção de carga de retorno e do menor tempo de espera (em decorrência da maior eficiência nas operações de carga e descarga desses portos).

Binkley \& Harrer (1981) salientam que, pelo fato de utilizarem dados individuais de movimentações de grãos, a agregação desses dados pode trazer alguns viéses, pois as variáveis utilizadas provavelmente não observam um comportamento homogêneo em 
todas as observações, atentando para o fato de que os coeficientes encontrados nesse tipo de trabalho devem ser interpretados apenas como uma tendência de comportamento do transporte marítimo de grãos.

Byington \& Olin (1983), por sua vez, concluem que a elasticidade-preço da demanda por exportação e importação de produtos manufaturados nos Estados Unidos pode influenciar a discriminação de fretes praticados pelas empresas americanas. Segundo os autores, os fretes para exportação (com menor elasticidade-preço da demanda) apresentaram maiores valores que os fretes para importação, em um mercado dominado por poucas empresas de transporte.

Os autores argumentam que, de acordo com Henderson \& Quandt $(1971)^{5}$, em mercados monopolizados, existe uma relação inversa entre a elasticidade-preço da demanda por serviços e o preço cobrado pelo monopolista, de forma que, quanto menor a elasticidade-preço da demanda, maior o preço cobrado pelo serviço.

Para chegar a essa conclusão, o trabalho baseou-se em um modelo log-linear de equações simultâneas e na utilização do método de mínimos quadrados de dois estágios, através de dois conjuntos (um para exportação e outro para importação) de três equações, sendo cada conjunto formado por uma equação de oferta de bens para exportação/importação, uma de demanda e uma terceira equação de equilíbrio.

Beilock et al. (1986) confirmam que os valores de frete variam para diferentes produtos em uma mesma rota, e para um mesmo produto em diferentes rotas, destacando que no trabalho de Beilock \& Shonkwiler ${ }^{6}(1983)$ atribui-se essa variação ao maior nível de perecibilidade de alguns produtos, assim como à compatibilidade de algumas commodities em carregamentos mistos. Os autores argumentam, porém, que algumas características, tais como oferta de serviços de transporte, possibilidade de carga de retorno, expectativa de variação no preço do produto transportado, tempos de carga e perecibilidade, podem influenciar o valor do frete praticado para transporte rodoviário de alimentos em diferentes rotas americanas.

\footnotetext{
${ }^{5}$ HENDERSON, J.; QUANDT, R. Microeconomic Analysis. New York: McGraw-Hill, 1971.
}

${ }^{6}$ BEILOCK, R.; SHONKWILER, S. Modeling weekly truck rates for perishables. Southern Journal Agricultural Economics. v. 15, p.83-87, 1983. 
Para tanto, os autores desenvolveram um modelo tipo próbite, baseado em variáveis binárias resultantes de uma pesquisa de campo junto aos corretores e transportadores, buscando-se identificar as diferentes reações da oferta e da demanda por transporte, para diferentes arranjos das variáveis consideradas.

Hauser (1986), por sua vez, estima dez funções de custo rodoviário em função de rotas de distâncias distintas para o transporte de carga nos Estados Unidos, combinandoas através de uma regressão obtida por mínimos quadrados, resultando em uma única função de frete rodoviário. O autor concluiu que, devido à alta competitividade da indústria de transporte rodoviário de grãos, o preço do frete é equivalente aos custos operacionais mais uma margem de $2 \%$ de lucro.

Prentice \& Benell (1992), por outro lado, utilizam um modelo de regressão linear múltipla para estimar a utilidade de carreteiros americanos em transportar cargas com diferentes arranjos de atributos (origem, destino, tipo de carga, tempo de espera para carregamento).

Hsu \& Goodwin (1995), utilizando um modelo vetorial auto-regressivo (VAR), estudam as relações dinâmicas entre o preço do frete marítimo de grãos e quatro componentes: preço do combustível, entrada de novos transportadores, carga parada e número de cargas transportadas. Entre os resultados encontrados, identificou-se que o preço do frete responde rapidamente às mudanças no preço do combustivel e à entrada de novos transportadores.

Segundo os autores, modelos vetoriais auto-regressivos são utilizados para examinar a relação dinâmica entre componentes inter-relacionados. Portanto, sua utilização não é conveniente para a realização do presente trabalho, visto que este estudo utiliza algumas variáveis exógenas que apresentam uma relação causal em um único sentido, tais como as condições climáticas e os aspectos geográficos.

Allen \& Liu (1995) mostram que a qualidade do serviço de transporte rodoviário de carga nos Estados Unidos está relacionada com o tamanho da empresa prestadora de serviços, sendo que os ganhos de escala permitem que as empresas prestem serviços de melhor qualidade ou mais baratos que as pequenas empresas. Os autores estimaram uma função custo de transporte de longo prazo para veículos "less-than-truckload" (LTL), 
compreendendo o período de 1985 a 1989, utilizando a forma geral especificada através de uma função translog de segunda ordem.

Veenstra \& Franses (1997) elaboram um modelo de série temporal multivariável (modelo vetorial autoregressivo - VAR) para identificar se os preços dos fretes marítimos de carga seca praticados em diferentes regiões são correlacionados. Os resultados demonstraram que as séries são não-estacionárias e que existe uma relação de cointegração entre algumas das séries analisadas, evidenciando uma relação de longo prazo entre os valores dos fretes.

Beilock et al. (1996) desenvolvem um estudo para identificação dos determinantes do frete rodoviário para movimentação internacional na Europa e no Oeste da Ásia. Os fatores identificados como determinantes do frete praticado foram: a travessia de fronteiras, condições das vias e o uso ou não de balsas para a travessia de canais.

Os autores salientam que, embora a possibilidade de carga de retorno seja um fator importante na determinação do frete, esta não foi considerada no estudo, pois os dados referem-se a uma categoria de transportadores que não procuram por carga de retorno.

Os autores desenvolveram três variações de um mesmo modelo: uma considerando apenas a distância percorrida (rodoviária e balsa) como variável explicativa; um segundo modelo adicionando uma variável para captar a influência da travessia de fronteiras de países sobre o frete; e um terceiro modelo, mais completo, em que, além das variáveis expostas, inclui variáveis que captam a influência das condições das vias utilizadas sobre o preço do transporte, agregando regiões em condições similares de trânsito, como especificado pelo modelo representado na equação (6):

$$
\begin{aligned}
R A T E= & b_{0}+b_{1} L D+b_{2} L D C E+b_{3} L D W F S U+b_{4} L D E F S U \\
& +b_{5} L D M E+b_{6} W D+b_{7} W D B S+b_{8} B D R+b_{9} B D R C E \\
& +b_{10} B D R F S U+b_{11} B D R M E+b_{12} W A T+e
\end{aligned}
$$

onde: 
$R A T E=$ frete praticado;

$L D=$ distância rodoviária em quilômetros;

$W D=$ distância fluvial em quilômetros;

$B D R=$ número de passagens por fronteiras;

$W A T$ = variável binária (igual a um, se for utilizado balsa para a travessia de canais, e zero no caso contrário);

$C E, F S U, W F S U, E F S U, M E$ e $B S=$ Europa Central, antiga União Soviética, Oeste da antiga União Soviética, Leste da antiga União Soviética, Meio Oeste da Ásia, e Mar Negro, respectivamente;

$b_{0}, b_{1}, \ldots, b_{12}=$ coeficientes a serem estimados;

$e=$ erro da estimativa.

As conclusões elaboradas por Beilock et al. (1996) evidenciam a existência de um prêmio para movimentações nos países da antiga União Soviética, o que se credita à infra-estrutura pouco adequada do país e à falta de segurança das estradas locais. Por outro lado, a travessia das fronteiras entre os países da antiga União Soviética e meio leste europeu foi o elemento que apresentou maior impacto sobre os fretes, o que se acredita ser causado pelo pagamento de tarifas adicionais, pelo maior tempo de espera nas fronteiras e pela falta de segurança nas estradas. Tais evidências puderam também ser confirmadas na região dos Balcãs, em estudo conduzido por Beilock \& Stanchev (1997).

Garrido (1998) desenvolve um modelo de demanda por transporte para identificar a correlação no fluxo de transporte rodoviário entre o México e o Texas, valendo-se de um modelo STARMA (Space Time Autoregressive Moving Average Model), considerando a interação entre tempo e espaço na determinação do fluxo de transporte.

Woudsma (1999) explora as conseqüências da abertura comercial promovida pelo Acordo de Livre Comércio da América do Norte (North American Free Trade Agreement - Nafta) sobre o setor de transporte americano, utilizando-se de indicadores 
tais como: receita, volume transportado, distância, tipo de produto e destino das cargas, tendo como origem uma região específica do Canadá (Ontário), para identificar mudanças de padrão comercial. A pesquisa revelou que o livre comércio alterou as relações comerciais entre os países, mudando as características do fluxo geográfico de transporte e que, apesar da fragilidade da análise, o livre comércio pode ter ajudado o setor de transporte de Ontário devido à sua maior eficiência na prestação do serviço de transporte.

Garrido \& Mahmassani (2000) desenvolvem um modelo de previsão para demanda de transporte em função da variabilidade da demanda em função do tempo e espaço, utilizando-se de um modelo multinomial próbite (MNP), através de uma simulação Monte-Carlo para avaliar a verossimilhança do MNP.

O modelo desenvolvido pelos autores considerou a demanda por frete como um processo estocástico, identificado por um modelo econométrico com uma função de distribuição de probabilidade com interação entre as alternativas consideradas. A demanda por transportes $(S)$ foi determinada como sendo função $(f)$ de uma série de variáveis, conforme mostra a equação (7):

$S=f(C, O, D, t)$

onde:

$C=$ commodity;

$O=$ origem;

$D=$ destino;

$t=$ tempo de viagem.

Miljkovic et al. (2000) desenvolvem um modelo econométrico para identificar a influência de certos fatores (sazonalidade da demanda, custo de oportunidade de se transportar outros produtos, custos operacionais etc.) sobre os fretes fluviais e 
ferroviários para movimentação de grãos do meio-oeste americano para o Golfo do México.

Os autores utilizaram um sistema log-log de quatro equações (um par de equações de oferta e demanda para o transporte fluvial e outro para o modal ferroviário), valendo-se do método de mínimos quadrados em três estágios, a partir do sistema de equações representado pelas expressões (8) a (11).

$$
\begin{aligned}
& B R A T_{t}=\alpha_{0}+\beta_{1} B R A T_{t-1}+\beta_{2} I L G B_{t+1}+\beta_{3} G U E X_{t+2} \\
& +\beta_{4} \text { Spread }_{t-2}+\beta_{5} \text { PILG }_{t}-\eta_{i} \sum_{i} \text { Seasonal }_{t}+\varepsilon_{0} \\
& I L G B_{t+2}=\alpha_{1}-\gamma_{I} I L G B_{t+1}+\gamma_{2} B R A T_{t}+\gamma_{3} G U E X_{t+2} \\
& -\omega_{i} \sum_{i} \text { Seasonal }_{t}+\varepsilon_{l} \\
& P_{I L G}=\alpha_{2}+\mu_{1} P_{I L G_{t-1}}+\mu_{2} B R A T_{t}+\mu_{3} I L G T_{t+1} \\
& +\mu_{4} \text { Spread }_{t-2}+\mu_{5} \text { GUEX }_{t+2}+\delta_{i} \sum_{i} \text { Seasonal }_{t}+\varepsilon_{2} \\
& I L G T_{t+2}=\alpha_{3}-\theta_{I} I L G T_{t+1}+\theta_{2} P_{I L G_{t}}+\theta_{3} \text { GUEX }_{t+2} \\
& -\zeta_{i} \sum_{i} \text { Seasonal }_{t}+\varepsilon_{3}
\end{aligned}
$$

onde:

$\alpha_{i}=$ constantes;

$t=$ período;

$\beta_{i}, \gamma \eta_{i}, \omega_{i}, \mu_{i}, \delta_{i}, \theta_{i}, \xi_{i}=$ coeficientes;

$B R A T=$ tarifa spot do transporte fluvial (porcentagem);

$I L G B=$ embarque fluvial $(\mathrm{t})$;

$P I L G=$ frete ferroviário de Illinois para o Golfo do México (US\$/t.milha);

$I L G T=$ embarque ferroviário de Illinois para o Golfo do México $(\mathrm{t})$;

Spread $=$ preço spread do milho do Pacífico Noroeste para o Golfo do México (cents/bushel);

GUEX = total de grãos exportados a partir do Golfo do México (t); 
Seasonal = variáveis dummy para os trimestres do ano;

$\varepsilon_{i}=$ erro aleatório.

Miljkovic et al. (2000) concluem que, mesmo que a flutuação na demanda por transportes dificulte a precisão das influências desses fatores sobre o frete, a natureza substitutiva entre os modais ferroviário e fluvial e a relação preço-quantidade são os fatores que apresentam maior influência sobre as taxas praticadas.

A Tabela 6 apresenta os trabalhos científicos abordados, destacando com a letra xis maiúscula $(\mathrm{X})$ as variáveis utilizadas em cada um dos estudos, consideradas relevantes na determinação dos valores dos fretes praticados, assim como a abordagem matemática utilizada, para salientar as similaridades dos trabalhos abordados.

Entre as técnicas utilizadas, destacam-se os modelos de regressão múltipla, modelos de mínimos quadrados e modelos auto-regressivos, variando de acordo com as características dos dados utilizados e das diferenças metodológicas envolvidas nos trabalhos de pesquisa. Nota-se assim que não existe uma técnica preferencial, mas sim a busca por uma metodologia que melhor se adapte às características do estudo.

Alguns fatores, como a distância percorrida, características dos pontos de origem e destino das cargas, época do embarque, tipo da carga e mesmo o valor do produto transportado, entre outros, aparecem com mais freqüência em estudos dessa natureza.

Por outro lado, outros fatores mais específicos, como greve dos portuários, utilização de balsas e características do transportador também se fazem presentes, embora isso ocorra apenas em estudos isolados em que fatores menos abrangentes surtem influências em determinados objetos de pesquisa. 


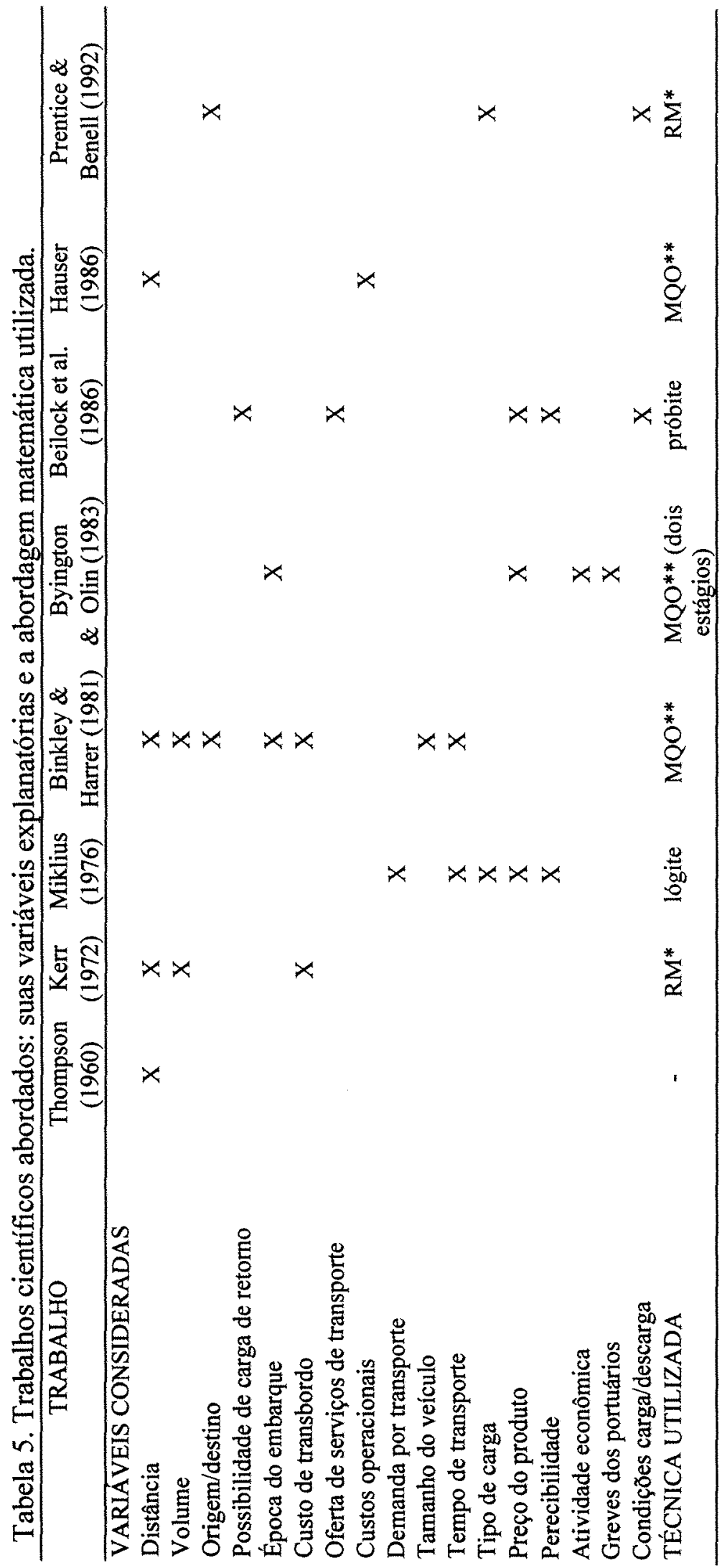




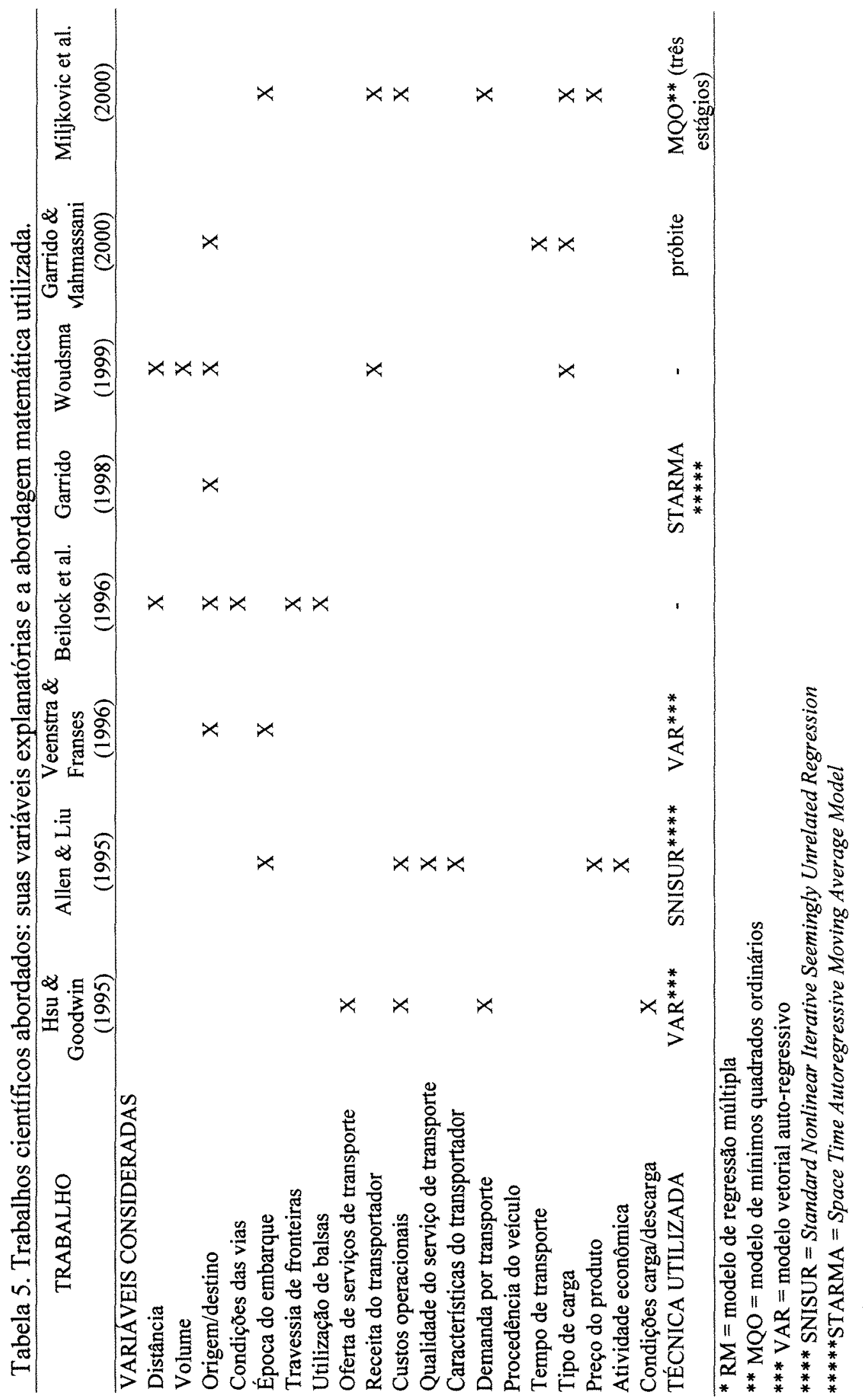


Em decorrência desse levantamento realizado, optou-se no presente trabalho por estimar os valores de frete através de um modelo de regressão linear múltipla, a partir do método dos mínimos quadrados ordinários (MQO).

Assim, optou-se primeiramente pela elaboração de um modelo geral que pudesse captar a influência dos fatores selecionados sobre toda a população estudada, que será chamado de Modelo Geral, de acordo com a equação (12). Este modelo geral poderá ser aplicado a conjuntos de dados diferenciados pelo ano de observação específico e pela caracterização de período de safra ou entressafra.

$$
\begin{aligned}
& \text { FRETE }_{i j}=\beta_{1}+\beta_{2} \text { DISTANCIA }_{i j}+\beta_{3} \text { VIA }_{i j}+\beta_{4} \text { PEDAGIO }_{i j} \\
& +\beta_{5} \text { RETORNO }_{i j}+\varepsilon
\end{aligned}
$$

onde:

$F R E T E_{i j}=$ valor real estimado do frete, em reais por tonelada, para o transporte de soja em grãos com origem $i$, destino $j$;

$D I S T A N C L A_{i j}=$ distância percorrida, em quilômetros, entre o ponto de origem $i$ e destino $j$

$V I A_{i j}=$ estado de conservação da via entre os pontos $i$ e $j$ (sendo igual a 1 para vias bem conservadas e zero para as demais vias);

$P E D A G I O_{i j}=$ soma do número de pedágios na rota $i j$;

RETORNO $\mathrm{J}_{j}=$ possibilidade de carga de retorno no destino $j$ (variável binária igual a um para movimentações com destino aos portos de Santos e Paranaguá e zero para outros destinos);

$\beta_{k}=$ coeficientes a serem estimados, sendo $k=1, \ldots, 5$;

$\varepsilon=$ erro de estimativa.

Como pode ser observado na equação (12), o modelo apresentado procura captar a influência de determinados fatores sobre o valor do frete praticado, tais como a 
distância percorrida, condições das estradas, o número de pedágios e a possibilidade de se conseguir carga de retorno.

Pretende-se aplicar a forma funcional representada pela equação (12) para a elaboração de dezoito modelos distintos, baseados em conjuntos de dados organizados por estado de origem (Goiás, Mato Grosso e Paraná), período do ano (safra, representada por observações relativas aos meses de março e abril de cada ano; entressafra, representada por observações de dezembro e janeiro do ano subsequente) e ano de referência $(1998,1999$ e 2000).

Espera-se, então, que o efeito da sazonalidade da demanda sobre os preços dos fretes possa ser captado pelas diferenças nos modelos gerados para os períodos de safra e de entressafra.

$\mathrm{Na}$ realização dos procedimentos econométricos, para concepção desses modelos e geração dos testes relacionados, será utilizado o software E-Views (1998).

\subsection{Especificação dos dados}

Uma vez definida a abordagem econométrica mais adequada para o estudo em questão, procurou-se coletar dados secundários de séries históricas relativamente abrangentes junto a entidades que elaboram acompanhamentos das variáveis especificadas no modelo proposto.

A variável dependente $\left(F R E T E_{i j}\right)$, especificada como o valor real médio do frete rodoviário de soja a granel, em reais por tonelada $(\mathrm{R} \$ / \mathrm{t})$, praticado nos principais corredores do país, em função das cidades de origem/destino, distância percorrida, período (safra ou entressafra) e ano, é baseada em um conjunto de dados composto por 1.828 observações mensais em 598 trechos diferentes (pares de origem e destino), levantados junto ao Sistema de Informações de Fretes (SIFRECA), compreendendo as safras de 1998 até a entressafra de 2000/2001.

O SIFRECA é um projeto de acompanhamento dos valores de frete praticados no Brasil para o transporte de produtos agrícolas e outros segmentos da agroindústria, para diferentes modais, coordenado por profissionais do Departamento de Economia, 
Administração e Sociologia da Escola Superior de Agricultura "Luiz de Queiroz" (ESALQ) da Universidade de São Paulo (USP).

Assim, a série de dados utilizada no presente trabalho é formada pelas informações processadas pelo SIFRECA e obtidas junto a produtores, processadores, traders e outros que realizam o transporte rodoviário de soja a granel em diferentes regiões brasileiras.

Vale destacar que os dados fornecidos referem-se aos valores médios e nominais do frete rodoviário de soja a granel praticado por empresas de transportes, o que exclui transportadores autônomos, e sem incluir impostos e seguros.

Para a transformação da base de dados em termos reais, os valores de frete foram deflacionados pelo Índice Nacional de Preços ao Consumidor do Instituto Brasileiro de Geografia e Estatística (INPC/IBGE), com base em fevereiro de 2001.

Além dos valores dos fretes $(\mathrm{R} \$ / \mathrm{t})$ e dos pares de origem e destino, outra informação obtida junto à base de dados do SIFRECA foi a distância percorrida em cada uma das observações, representada pela variável DISTANCIA $i j$ no modelo especificado. Essas distâncias são obtidas junto aos próprios informantes, publicações e softwares relacionados, como Energy Roadshow@ (Descartes, 1998), Infoguia® (GFMI, 1998), entre outros.

Devido à grande complexidade da malha rodoviária brasileira $\mathrm{e}$ ao número elevado de trechos utilizados, a tarefa de composição das variáveis $V L A_{i j}$ e $P E D A G I O_{i j}$ mostrou-se um tanto árdua, sendo necessárias algumas simplificações para a composição das séries de dados.

Assim sendo, foram analisados todos os trechos das observações obtidas através da utilização do software Infoguia ${ }^{\circledR}$ (GFMI 1998) para roteirização do melhor percurso entre os pares de origem e destino, sendo possível a identificação de todos os segmentos de rodovias percorridos na rota proposta.

Alguns pontos de origem e destino não foram encontrados no banco de dados do software utilizado por tratarem-se principalmente de municípios recém-formados ou regiões rurais. Assim, foram consideradas as cidades mais próximas dessas regiões como 
pontos de referência (vide Tabela A do Apêndice 1), identificadas através de contatos telefônicos com empresas do setor que atuam nessas áreas.

Para seleção das melhores e piores rodovias do país, foram utilizadas a Pesquisa Rodoviária da Confederação Nacional de Transporte (1999b, 2000), indistintamente, isto é, não considerando o trecho da rodovia percorrido, ou o ano de qualificação do estado de conservação da rodovia pesquisada. Com isto, procurou-se identificar apenas se determinada rodovia, em algum momento, foi selecionada entre os melhores ou piores trechos pesquisados.

Desta forma, para a composição da variável $V I A_{i j}$, optou-se por identificar em cada percurso as rodovias utilizadas, sendo creditado o valor um para os percursos que utilizaram, em algum momento, uma das rodovias listadas nas pesquisas como as melhores rodovias do país, mesmo que, na maior parte do percurso, tenham sido utilizadas rodovias que não figuraram entre as melhores ou piores.

De outro modo, para as observações em que foram identificados trechos de rodovias que figuram nas duas listagens, em momentos diferentes, como no caso da BR 116 , ou que passam seqüencialmente por algumas vias consideradas pelas pesquisas elaboradas pela Confederação Nacional de Transporte (1999b, 2000) em bom estado de conservação e outras degradadas, foram creditados o valor zero. $\mathrm{O}$ mesmo valor foi pontuado para as observações que realizaram trajetos em rodovias que não figuraram nas listas das referidas pesquisas.

Para a composição da variável $P E D A G I O_{i j}$, foi utilizado um critério de análise similar. Desta forma, para cada trecho observado, procurou-se, dentro do possível, identificar o número de pedágios existentes no trajeto realizado, baseado nas informações geradas pelo Infoguia® e nas informações de localização das praças de pedágios federais, estaduais e municipais obtidas junto à Associação Brasileira de Concessionárias de Rodovias - ABCR (2000), apresentadas na Tabela B do Apêndice 1.

Assim, para cada praça de pedágio identificada, independente do sentido da cobrança ou do valor cobrado, somou-se uma unidade à variável $P E D A G I O_{i j}$, o mesmo ocorrendo no caso da utilização de balsas para travessias de rios. Portanto, no caso de um trajeto em que foram identificadas oito praças de pedágio, por exemplo, e nenhum 
deslocamento através de balsas, a variável $P E D A G I O_{i j}$ assumiu o número oito e assim sucessivamente.

Vale destacar que, em função do recente processo de privatizações de rodovias, algumas novas concessões passaram a vigorar durante $o$ período analisado, principalmente durante o ano 1998, com destaque para a região Sul do país.

Em função da pouca clareza na composição do trajeto realizado pelo software utilizado para composição do roteiro e da dificuldade para localização de algumas praças de pedágios, provavelmente, em muitos casos, o número de praças computadas não espelha exatamente a realidade, podendo haver um desvio de uma ou duas praças, principalmente em trajetos longos, em que se observa um número elevado de concessionárias em operação.

Outro agravante é que, mesmo que a ABCR apresente informações bastante abrangentes sobre as concessionárias rodoviárias, provavelmente, em função do ritmo acelerado de transformações no processo de concessão da malha rodoviária brasileira, algumas praças de pedágios que já se encontram em funcionamento podem não ter sido informadas.

Soma-se a isto o fato de não ser considerado o valor de pedágio cobrado nessas praças, o que pode trazer algum tipo de viés, uma vez que esses valores podem variar consideravelmente.

Porém, apesar dessas limitações, acredita-se que a série de dados que compõe a variável $P E D A G I O_{i j}$ é bastante significativa para a captação do efeito da existência ou não de pedágios sobre os valores dos fretes praticados.

Para composição da variável binária $R E T O R N O_{j}$, consideraram-se as cidades portuárias de Paranaguá e Santos como potenciais candidatas para obtenção de carga de retorno, em função dos desembarques das importações, sendo que a cidade de Guarujá também foi considerada na análise, em virtude de sua proximidade com a cidade de Santos. Assim, todas as movimentações com destino a essas cidades assumiram valor um, sendo que o transporte de soja para os demais destinos assumiu valor zero. 
$\mathrm{Na}$ Tabela $\mathrm{C}$ do Apêndice 1 encontra-se uma amostra dos valores de fretes utilizados, discriminando origem, destino, distância, mês/ano de referência, estado da via, número de pedágios e possibilidade de carga de retorno, está reproduzida. 


\section{RESULTADOS}

Neste capítulo é apresentada, em sua primeira seção, uma análise descritiva dos dados utilizados. A seguir, é realizada uma discussão sobre os principais resultados encontrados para a estimação do valor do frete praticado para transporte rodoviário de soja a granel em diferentes regiões brasileiras, a partir do modelo econométrico proposto.

\subsection{Avaliação das observações de valores de frete rodoviário de soja}

Os dados de frete foram obtidos junto ao Sistema de Informação de Fretes (SIFRECA) e classificados, primeiramente, em função dos estados de origem das movimentações de soja.

Assim, para cada um dos três estados de origem sob estudo (Goiás, Mato Grosso e Paraná) têm-se três conjuntos de dados, representando as safras dos anos de 1998, 1999 e 2000, e outros três conjuntos de dados representando as entressafras de 1998/1999, 1999/2000 e 2000/2001.

Os três conjuntos de dados que representam as safras foram definidos através da seleção de movimentações ocorridas nos meses de março e abril de cada um dos anos $(1998,1999$ e 2000), totalizando assim nove conjuntos de dados.

Os conjuntos de dados que representam as entressafras, por outro lado, foram organizados através da seleção de movimentações nos meses de dezembro e janeiro de cada ano. Assim, para cada estado de origem tem-se um conjunto de dados referentes a dezembro de 1998 e janeiro de 1999, representando a entressafra de 1998/1999; um segundo conjunto com dados de dezembro de 1999 e janeiro de 2000 (entressafra de 
1999/2000) e um terceiro conjunto de dados de dezembro de 2000 e janeiro de 2001 (entressafra de 2000/2001), totalizando, portanto, outros nove conjuntos de dados.

A totalidade de dados, abrangendo safra e entressafra, é representada nas Figuras 5 e 6. Para composição da Figura 5, agruparam-se todos os dados que representam os períodos de safra, independente do ano (1998 a 2000), sendo utilizado o mesmo princípio para composição da Figura 6, que apresenta os dados da entressafra.

As observações foram representadas de tal forma que no eixo das abcissas encontram-se as distâncias percorridas; e no eixo das ordenadas, o valor real do frete praticado, em $\mathrm{R} \$ / \mathrm{t}$ transportada, em cada uma das movimentações.

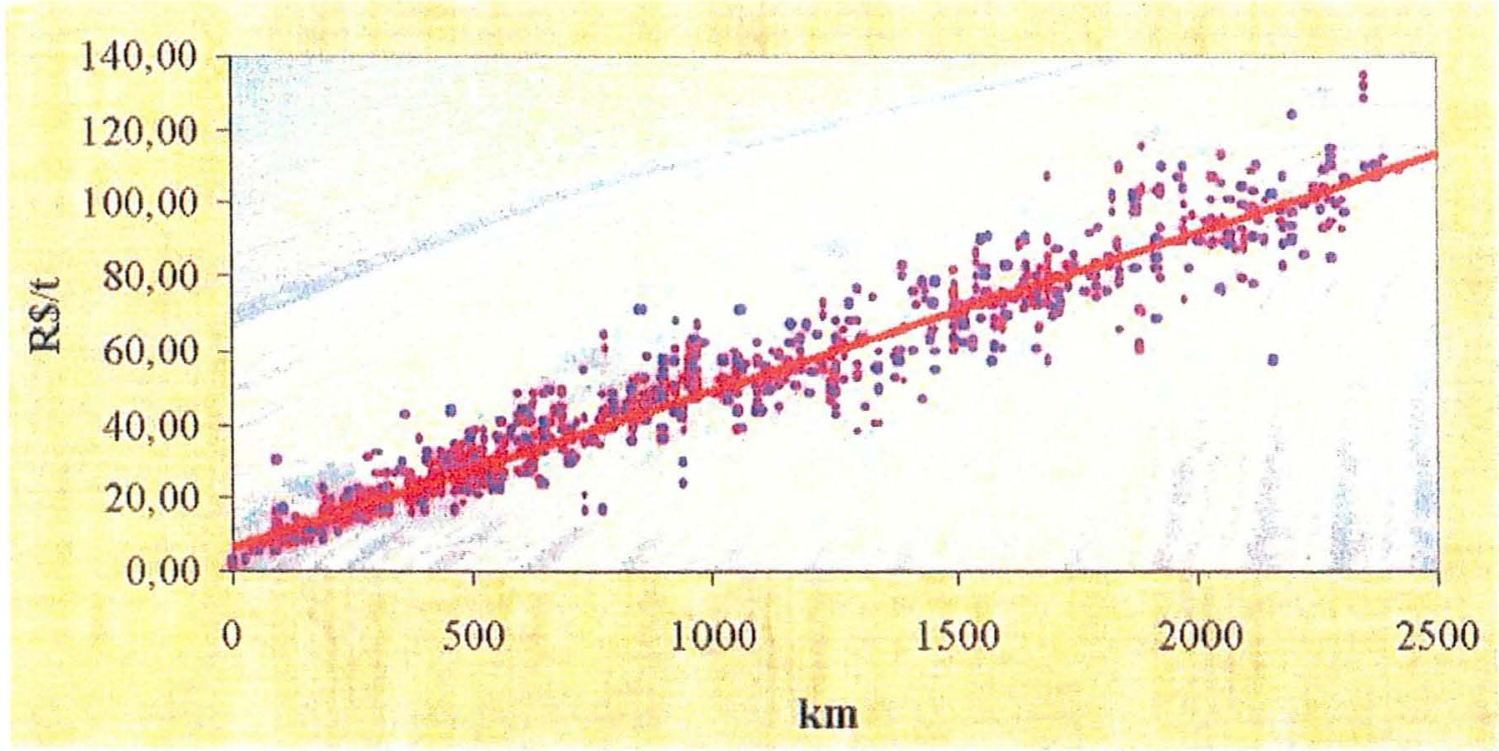

Figura 5 - Valores reais dos fretes praticados nas safras de 1998, 1999 e 2000 para transporte de soja a granel em diversas regiões brasileiras.

Fonte: SIFRECA 


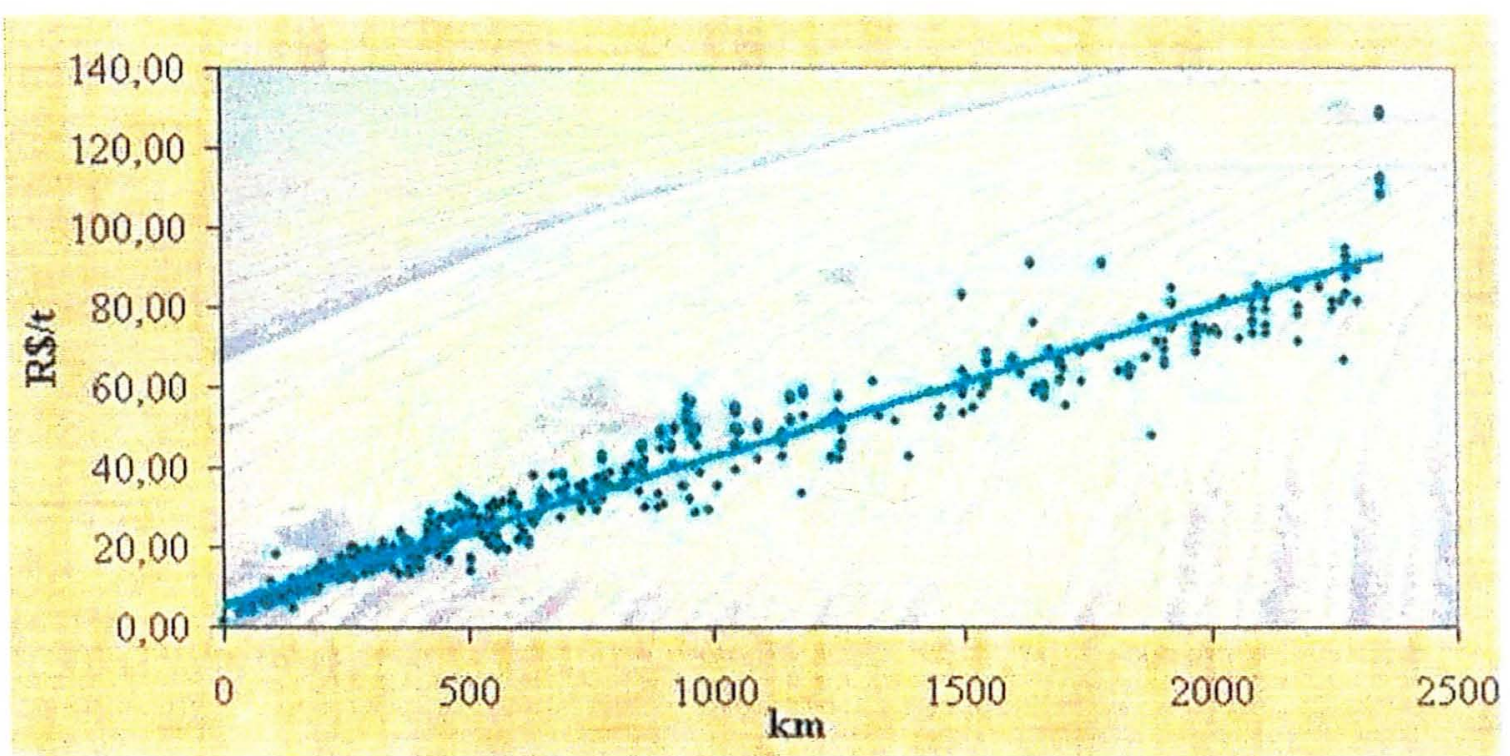

Figura 6 - Valores reais dos fretes praticados nas entressafras de 1998, 1999 e 2000 para transporte de soja a granel em diversas regiões brasileiras.

Fonte: SIFRECA

As Figuras 5 e 6 deixam evidente a relação direta entre distância percorrida e os valores praticados, ou seja, o frete cobrado tende a ser maior quanto maior a distância percorrida. Essa característica é intrínseca à atividade de transporte, visto que os custos operacionais variáveis de utilização dos veículos, tais como o gasto com combustível, óleos, lubrificantes, entre outros, são tanto maiores quanto maiores as distâncias, fenômeno que influencia diretamente os fretes praticados.

Em ambas as figuras, pode-se observar também que, para pequenas distâncias, existe uma maior sobreposição das observações, o que pode indicar que existe um fator comum, provavelmente baseado nos custos operacionais de transporte e distância percorrida, observados num mercado altamente concorrencial.

À medida que a extensão dos trajetos aumenta, os dados ficam cada vez mais dispersos, e talvez o número de transportadoras que se dispõe a efetuar esse tipo de serviço seja mais reduzido, o que pode indicar que, para maiores distâncias, a formação dos valores dos fretes é mais heterogênea pelo fato dos mesmos estarem sujeitos a uma maior gama de variáveis, tais como aquelas discutidas neste trabalho. 
Esse fenômeno também pode estar associado à heterocedasticidade do conjunto de dados. Assim, como forma de eliminar o efeito da heterocedasticidade dos resíduos sobre a estimação dos coeficientes, foi utilizada a matriz de variância e covariância proposta por White (1980) e que por sinal é uma das opções disponíveis para os usuários do software E-Views, utilizado nesse trabalho.

A Figura 7 apresenta as linhas de tendência que procuram identificar o comportamento associado aos conjuntos de observações plotadas nas Figuras 5 e 6 .

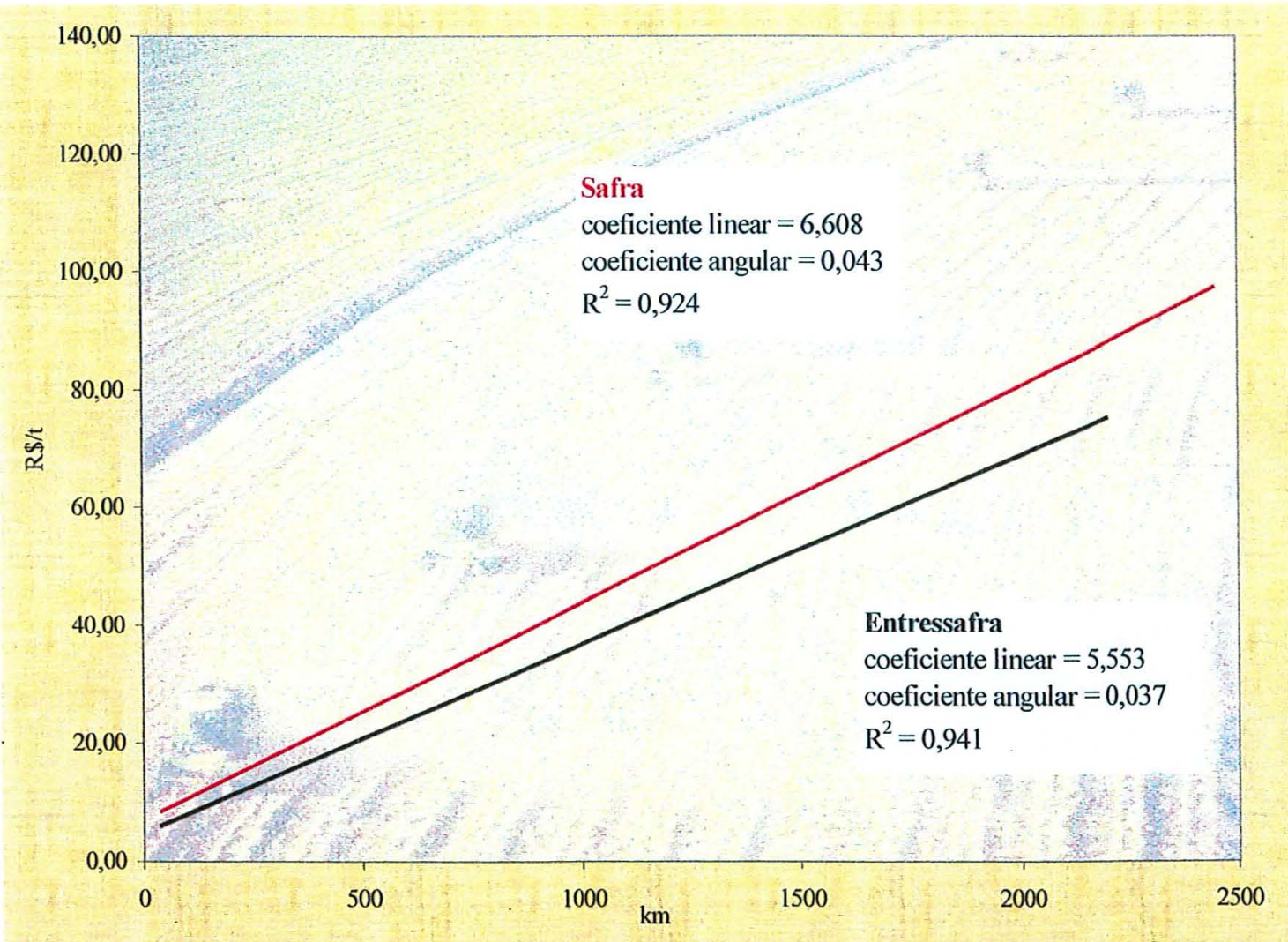

Figura 7 - Representações lineares dos dados utilizados, plotados nas Figuras 5 e 6.

Comparando-se essas retas (vide Figura 7), pode-se observar que as mesmas apresentam inclinações diferentes, sendo que aquela associada à safra observa uma maior inclinação. Conclui-se, assim, que nos períodos de safra, a variação marginal nos 
preços dos fretes praticados tende a ser maior que nos períodos de entressafras ou seja, para cada quilômetro adicional percorrido, os transportadores tendem a pedir um prêmio maior no periodo de safra que na entressafra.

Uma explicação para isto pode estar associada ao fato de que, ao percorrerem maiores distâncias, os transportadores incorrem em um maior custo de oportunidade por estarem um maior período fora de operação (retorno de destinos sem carga) em uma época de grande demanda. Esta característica reforça a validade do tratamento diferenciado dos períodos de safra e de entressafra.

A Tabela 6 ilustra algumas características dos dados utilizados para os períodos de safra. Nessa tabela estão pontuadas informações sobre: número de observações por conjunto de dados; principais cidades de origem das cargas; principais estados de destino das cargas e distância média dos percursos.

Tabela 6. Descrição dos dados utilizados para as safras de 1998 a 2000, por estado.

\begin{tabular}{|c|c|c|c|c|c|c|c|c|}
\hline \multirow{2}{*}{$\begin{array}{l}\text { Estado de } \\
\text { Origem }\end{array}$} & \multirow{2}{*}{$\begin{array}{l}\mathrm{n}^{\circ} \\
\text { obs. }\end{array}$} & \multirow{2}{*}{$\begin{array}{c}\text { distância } \\
\text { média } \\
(\mathrm{km})\end{array}$} & \multicolumn{3}{|c|}{ Principais cidades de origem } & \multicolumn{3}{|c|}{ Principais estados de destino } \\
\hline & & & nome & $\begin{array}{l}\mathrm{n}^{\circ} \\
\text { obs. }\end{array}$ & $\begin{array}{l}\text { Part. Relat. } \\
\text { (\%) }\end{array}$ & nome & $\mathrm{n}^{\circ}$ obs. & $\begin{array}{l}\text { Part. Relat. } \\
(\%)\end{array}$ \\
\hline \multirow[t]{3}{*}{$\mathrm{GO}$} & 395 & 528 & Rio Verde & 60 & $15 \%$ & $\mathrm{GO}$ & 207 & $52 \%$ \\
\hline & & & Montividiu & 42 & $11 \%$ & SP & 101 & $26 \%$ \\
\hline & & & Jataí & 40 & $10 \%$ & MG & 50 & $13 \%$ \\
\hline \multirow[t]{4}{*}{ MT } & 581 & 1.154 & Primavera do Leste & 73 & $13 \%$ & PR & 159 & $27 \%$ \\
\hline & & & L. do Rio Verde & 64 & $11 \%$ & SP & 117 & $20 \%$ \\
\hline & & & Sorriso & 56 & $10 \%$ & $\mathrm{MT}$ & 99 & $17 \%$ \\
\hline & & & & & & GO & 80 & $14 \%$ \\
\hline \multirow[t]{5}{*}{ PR } & 202 & 446 & Londrina & 31 & $15 \%$ & PR & 182 & $90 \%$ \\
\hline & & & Cascavel & 13 & $7 \%$ & & & \\
\hline & & & Toledo & 10 & $5 \%$ & & & \\
\hline & & & Maringá & 10 & $5 \%$ & & & \\
\hline & & & Campo Mourão & 10 & $5 \%$ & & & \\
\hline
\end{tabular}


Com relação aos dados de movimentações no período da safra, com origem no estado de Goiás, percebe-se que, das 395 observações, destaca-se a cidade de Rio Verde como principal origem das cargas, sendo que deste ponto partiram cerca de $15 \%$ das cargas, seguida por Montividiu com $11 \%$ e Jataí com 10\%. Assim, as três cidades juntas representam mais de um terço do total dos dados utilizados.

Isso ocorre porque essas cidades estão localizadas à margem de importantes rodovias, tal como a BR 060, que liga Jataí a Rio Verde, e a GO 174, que faz a ligação entre Montividiu e Rio Verde. Além disso, localizam-se na região centro-sul do estado de Goiás, onde se concentram as principais cidades produtoras de grãos do estado e que, por sinal, estão relativamente próximas entre si (Montividiu-Rio Verde, $55 \mathrm{~km}$ e Rio Verde-Jataí, $88 \mathrm{~km}$ ).

Por outro lado, o estado de Goiás, por ser um grande produtor de grãos e concentrar boa parte da indústria esmagadora do país, aparece como o mais importante destino das cargas com origem no próprio estado, o que contribui para que a distância média das movimentações com origem no estado seja de aproximadamente $528 \mathrm{~km}$.

Assim, do total das observações que representam as movimentações com origem no estado de Goiás, durante o período de safra, cerca de 52\% têm como destino o próprio estado, seguido por São Paulo (26\%), que tem clara importância como mercado consumidor e como canal de exportação.

Minas Gerais eqüivale a cerca de $13 \%$ dos destinos, apresentando-se como um entreposto das zonas produtoras para interligação com os maiores mercados consumidores e com os próprios canais de exportação. O estado de Minas Gerais também abriga algumas importantes indústrias esmagadoras de soja, principalmente na região de Uberlândia.

A Tabela 6 mostra também que, das 581 movimentações com origem no estado de Mato Grosso no período de safra, a distância média é de aproximadamente $1.154 \mathrm{~km}$, mais do que o dobro da distância média observada para as movimentações com origem em Goiás.

Isso ocorre porque apenas $17 \%$ dos destinos dessas cargas envolvem o próprio estado, sendo os estados do Paraná e São Paulo os mercados mais importantes, com 27\% 
e $20 \%$ de participação, respectivamente, o que contribui para que a distância média dos percursos seja elevada. Goiás aparece em quarto lugar, absorvendo cerca de $14 \%$ da soja com origem em Mato Grosso, tendo como principal destino a industrialização daquele grão.

Essa diversidade de estados de destino justifica-se pelo fato do estado do Mato Grosso caracterizar-se como um estado essencialmente produtor, sendo o único estado que apresenta déficit industrial no complexo soja (capacidade instalada menor que produção agrícola) entre os principais estados produtores do grão.

Segundo Castro et al. (2000), o estado de Mato Grosso apresenta um déficit no comércio interestadual de cargas, o que se justifica, segundo os autores, pelo fato de que o estado apresenta uma economia baseada na agropecuária e não possui um parque industrial desenvolvido.

Outra explicação para essa distância média dos percursos relativamente maior é o fato de duas das principais cidades de origem das cargas, por onde passa a BR 163, Lucas do Rio Verde (11\%) e Sorriso (10\%), estarem localizadas no centro do estado. Outra importante cidade de origem das cargas, porém mais a sudeste do estado, é Primavera do Leste, com $13 \%$ de participação sobre o total.

Assim como no caso de Goiás, a importância dessas cidades dentro da matriz de movimentação de grãos é conseqüência de sua inserção em regiões tipicamente produtoras, bem como de sua proximidade a importantes rodovias.

O caso de Londrina, no Paraná, é semelhante. De acordo com a Tabela 6, cerca de $15 \%$ das observações com origem no Paraná partem dessa cidade. A importância de Londrina nesse contexto advém de sua posição geográfica em relação: às zonas produtoras, tais como os estados de Goiás e Mato Grosso; e aos maiores mercados consumidores na região Sul do país, assim como ao porto de Paranaguá. Destaca-se também a facilidade de distribuição dos produtos pela cidade, que está localizada no entroncamento das mais importantes rodovias que passam pelo estado, como a BR 376 (Rodovia do Café), que liga a cidade de Londrina a Ponta Grossa e dá acesso a Paranaguá. 
Todos esses fatos, quando conjugados, fazem com que perto de $90 \%$ dos dados utilizados para o período de safra, com origem no Paraná, tenham por destino o próprio estado, contribuindo para que a distância média associada a esses seja de apenas $446 \mathrm{~km}$.

Através dessa análise pode-se concluir que existem peculiaridades nas movimentações com origem em cada um dos estados (GO, MT e PR), como a distância média dos percursos com origem no estado do Mato Grosso em relação aos outros estados, ou a concentração de movimentações intra-estaduais no Paraná, que podem contribuir para que a formação de preços de frete nesses estados seja distinta. Desta forma, é válido que sejam estimados modelos distintos para cada estado de origem para que estes fenômenos sejam melhor avaliados.

A Tabela 7 apresenta os mesmos resultados apresentados na Tabela 6, porém relacionados às observações de entressafra.

Tabela 7. Descrição dos dados utilizados para as entressafras de 1998 a 2001, por estado.

\begin{tabular}{|c|c|c|c|c|c|c|c|c|}
\hline \multirow{2}{*}{$\begin{array}{c}\text { Estado } \\
\text { de } \\
\text { Origem }\end{array}$} & \multirow{2}{*}{$\begin{array}{l}\mathrm{n}^{\circ} \\
\text { obs. }\end{array}$} & \multirow{2}{*}{$\begin{array}{c}\text { distância } \\
\text { média } \\
(\mathrm{km})\end{array}$} & \multicolumn{3}{|c|}{ Principais cidades de origem } & \multicolumn{3}{|c|}{ Principais estados de destino } \\
\hline & & & nome & $\begin{array}{l}\mathrm{n}^{\circ} \\
\text { obs. }\end{array}$ & $\begin{array}{l}\text { Part. Relat. } \\
\text { (\%) }\end{array}$ & nome & $\begin{array}{l}\mathrm{n}^{\circ} \\
\text { obs. }\end{array}$ & $\begin{array}{l}\text { Part. Relat. } \\
\text { (\%) }\end{array}$ \\
\hline \multirow[t]{3}{*}{ GO } & 355 & 382 & Jataí & 36 & $10 \%$ & GO & 255 & $72 \%$ \\
\hline & & & Rio Verde & 34 & $10 \%$ & SP & 43 & $12 \%$ \\
\hline & & & Montividiu & 27 & $8 \%$ & MG & 11 & $11 \%$ \\
\hline \multirow[t]{4}{*}{ MT } & 256 & 1.180 & Primavera do Leste & 55 & $21 \%$ & PR & 80 & $31 \%$ \\
\hline & & & Sorriso & 27 & $11 \%$ & GO & 71 & $28 \%$ \\
\hline & & & L. do Rio Verde & 25 & $10 \%$ & MT & 49 & $19 \%$ \\
\hline & & & & & & SP & 40 & $16 \%$ \\
\hline \multirow[t]{3}{*}{ PR } & 102 & 498 & Londrina & 30 & $30 \%$ & PR & 82 & $82 \%$ \\
\hline & & & Cascavel & 14 & $14 \%$ & RS & 8 & $8 \%$ \\
\hline & & & & & & SE & 6 & $6 \%$ \\
\hline
\end{tabular}

A Tabela 7 mostra que as cidades originadoras de cargas indicadas na Tabela 6 destacam-se também no período de entressafra, reafirmando a importância desses 
centros como pontos de distribuição de soja nos estados de origem, independentemente da época do ano.

Além disso, o que se observa através da análise da Tabela 7 é que, como o período de entressafra é uma época de desaquecimento da demanda por transporte, o número de observações disponíveis é menor.

Enquanto que no período de safra os números de observações para os estados de Goiás, Mato Grosso e Paraná totalizam respectivamente 395, 584 e 202, no período de entressafra, esses valores caem para 335, 256 e 102.

Outro fato interessante a ser observado é que, no período de entressafra, ocorre também uma redução sensível nos embarques de grãos para exportação, o que se reflete em um número menor de movimentações com destino a São Paulo.

Nota-se que, tanto para as movimentações com origem em Goiás como para aquelas com origem em Mato Grosso, existe uma redução da importância do estado de São Paulo na entressafra como destino das cargas, sendo que, no caso de Goiás, a participação de São Paulo passa de $26 \%$ no período de safra para $12 \%$ na entressafra. Já para Mato Grosso, essa participação é reduzida de $20 \%$ para $16 \%$.

Por outro lado, a importância relativa de Goiás como destino das cargas aumenta em ambos os casos, uma vez que o abastecimento da indústria da soja não pode ser interrompido.

Para as cargas com origem em Goiás, as movimentações intra-estaduais passam de $52 \%$ na safra para $72 \%$ na entressafra; já para a soja com origem em Mato Grosso, Goiás passa a representar $28 \%$ dos destinos na entressafra, contra $14 \%$ na safra.

A redução dos embarques para exportação também se reflete sobre as movimentações com origem no Paraná. Para essas observações, no período de entressafra (vide Tabela 7), o número relativo de movimentações intra-estaduais se reduz. Enquanto que, na safra, $90 \%$ das observações têm como destino o próprio estado (vide Tabela 6), no período de entressafra essa participação cai para cerca de $82 \%$.

Vale lembrar que, apesar de tratar-se das características de um conjunto específico de dados, pôde-se inferir que as características assinaladas têm estreita relação 
com a realidade, confirmando o fato de que a base de dados consultada é bastante representativa.

Nesse sentido, a Tabela 8 apresenta os principais estados de origem e destino do total de granéis sólidos agrícolas transportados durante o ano de 1996. Dada a representatividade da cultura da soja entre os granéis agrícolas produzidos no país, as relações entre origem e destino apresentadas na Tabela 8 guardam, de alguma forma, uma relação direta com as movimentações de soja no Brasil.

Tabela 8. Volume total de granéis sólidos agricolas transportados, em toneladas, entre os estados brasileiros durante o ano de 1996.

\begin{tabular}{ccc}
\hline Estado & Granéis agrícolas em $10^{3} \mathrm{t}$ & $\%$ \\
\hline Origem & 7.842 & $22,9 \%$ \\
GO & 11.479 & $33,6 \%$ \\
MT & 3.724 & $10,9 \%$ \\
PR & 11.165 & $32,6 \%$ \\
Outros & 34.210 & $100,0 \%$ \\
Total & & \\
& & \\
Destino & 1.386 & $4,1 \%$ \\
GO & 3.352 & $9,8 \%$ \\
MT & 8.480 & $24,8 \%$ \\
PR & 5.239 & $15,3 \%$ \\
SP & 15.753 & $46,0 \%$ \\
Outros & 34.210 & $100,0 \%$ \\
Total & &
\end{tabular}

Fonte: Anuário Estatístico de Transportes 1996 (1996)

De acordo com a Tabela 8, os estados de Goiás, Mato Grosso e Paraná representam 22,9\%,33,6\% e 10,9\% das origens das movimentações de granéis sólidos agrícolas, respectivamente, o que implica uma participação superior a $67 \%$ no total movimentado, reafirmando a importância desses estados dentro da matriz produtiva de grãos.

A Tabela 8 mostra, também, que para o total de granéis sólidos agrícolas transportados no país existe uma relação similar àquela encontrada nos conjuntos de dados utilizados no presente trabalho, ou seja, uma maior concentração no número de 
origens das cargas e uma maior diversificação de destinos, o que corrobora a representatividade dos dados utilizados.

\subsection{Estimação dos valores de frete rodoviário de soja em diferentes regiões brasileiras}

Vale destacar que, como especificado na equação (12), o modelo geral procura identificar algumas das principais variáveis que podem influenciar os valores dos fretes praticados pelos transportadores para a movimentação rodoviária de soja a granel no país.

Os testes revelaram que, para cada conjunto específico de observações, apenas algumas das variáveis se mostraram explicativas, a um nível de significância de $5 \%$, o que revela que as variáveis selecionadas atuam de formas distintas sobre os diferentes conjuntos de dados.

Para a análise que se segue, foram considerados os modelos completos, ou seja, as equações geradas incluem tanto as variáveis com coeficientes significativos como aqueles não significativos.

Os coeficientes significativos revelaram em sua maioria testes $t$ com significância inferior a $1 \%$, o que indica que, quando explicativas, as variáveis mostraram-se estatisticamente diferentes de zero a um nível de significância muito inferior ao limite estipulado ( $5 \%$ de significância).

As estatísticas Durbin-Watson dos modelos de safra e de entressafra, em sua grande maioria, não indicaram correlação de primeira ordem dos resíduos calculados, o que contribui para a aceitação de que os erros padrões das equações foram corretamente estimados.

Os relatórios emitidos pelo software E-Views estão reproduzidos no Apêndice 2. Análises detalhadas dos resultados contido nesses relatórios são apresentadas nas próximas seções. 


\subsubsection{Estimativas para os períodos de safra}

A Tabela 9 mostra os principais resultados obtidos para os períodos de safra.

Tabela 9. Principais resultados dos modelos de estimação do valor do frete praticado para o transporte rodoviário de soja a granel, com origem nos estados de Goiás, Mato Grosso e Paraná, nos períodos de safra dos anos de 1998 a 2000 (os valores entre parênteses referem-se aos testes $t$ ).

\begin{tabular}{|c|c|c|c|c|c|c|c|c|c|}
\hline $\begin{array}{c}\text { Variável/ } \\
\text { Estatísticas }\end{array}$ & $\begin{array}{c}\text { GO } \\
1998\end{array}$ & $\begin{array}{c}\text { GO } \\
1999\end{array}$ & $\begin{array}{c}\text { GO } \\
2000\end{array}$ & $\begin{array}{c}\text { MT } \\
1998\end{array}$ & $\begin{array}{l}\text { MT } \\
1999\end{array}$ & $\begin{array}{c}\text { MT } \\
2000\end{array}$ & $\begin{array}{c}\text { PR } \\
1998\end{array}$ & $\begin{array}{c}\text { PR } \\
1999\end{array}$ & $\begin{array}{c}\text { PR } \\
2000\end{array}$ \\
\hline Constante & $\begin{array}{c}6,107 \\
(9,800)^{*}\end{array}$ & $\begin{array}{c}5,798 \\
(10,440)^{*}\end{array}$ & $\begin{array}{c}7,635 \\
(10,599)^{*}\end{array}$ & $\begin{array}{c}9,429 \\
(4,332)^{*}\end{array}$ & $\begin{array}{c}13,662 \\
(7,652)^{*}\end{array}$ & $\begin{array}{c}11,325 \\
(7,661)^{*}\end{array}$ & $\begin{array}{c}1,716 \\
(1,991)\end{array}$ & $\begin{array}{c}3,708 \\
(2,952)^{*}\end{array}$ & $\begin{array}{c}3,120 \\
(8,849)^{*}\end{array}$ \\
\hline Distância & $\begin{array}{c}0,040 \\
(21,401)^{*}\end{array}$ & $\begin{array}{c}0,040 \\
(22,724)^{*}\end{array}$ & $\begin{array}{c}0,035 \\
(19,410)^{*}\end{array}$ & $\begin{array}{c}0.039 \\
(22,226)^{*}\end{array}$ & $\begin{array}{c}0,036 \\
(22,401)^{*}\end{array}$ & $\begin{array}{c}0,034 \\
(22,506)^{*}\end{array}$ & $\begin{array}{c}0,054 \\
(45,315)^{*}\end{array}$ & $\begin{array}{c}0,054 \\
(66,650)^{*}\end{array}$ & $\begin{array}{c}0,046 \\
(29,092)^{*}\end{array}$ \\
\hline Via & $\begin{array}{c}-3,068 \\
(-2,946)^{*}\end{array}$ & $\begin{array}{c}0,780 \\
(0,663)\end{array}$ & $\begin{array}{c}-1,929 \\
(-1,382)\end{array}$ & $\begin{array}{c}-1,827 \\
(-1,579)\end{array}$ & $\begin{array}{c}-0,258 \\
(-0,197)\end{array}$ & $\begin{array}{c}2,377 \\
(1,478)\end{array}$ & $\begin{array}{c}4,882 \\
(3,872)^{*}\end{array}$ & $\begin{array}{c}1,963 \\
(1,288)\end{array}$ & $\begin{array}{c}2,347 \\
(3,397)^{*}\end{array}$ \\
\hline Pedágio & $\begin{array}{c}1,008 \\
(2,776)^{*}\end{array}$ & $\begin{array}{c}1,425 \\
(2,803)^{*}\end{array}$ & $\begin{array}{c}1,165 \\
(3,258)^{*}\end{array}$ & $\begin{array}{c}0,938 \\
(2,509)^{*}\end{array}$ & $\begin{array}{c}1,596 \\
(2,751)^{*}\end{array}$ & $\begin{array}{c}1,817 \\
(2,238)^{*}\end{array}$ & $\begin{array}{c}-1,175 \\
(-2,221)^{* *}\end{array}$ & $\begin{array}{c}-0,349 \\
(-1,077)\end{array}$ & $\begin{array}{c}-0,229 \\
(-0,660)\end{array}$ \\
\hline Retorno & $\begin{array}{c}-4.959 \\
(-1,842)\end{array}$ & $\begin{array}{c}-4,312 \\
(-0,982)\end{array}$ & $\begin{array}{c}-2,670 \\
(-1,024)\end{array}$ & $\begin{array}{c}2,131 \\
(0,539)\end{array}$ & $\begin{array}{c}1,682 \\
(0,548)\end{array}$ & $\begin{array}{c}0,711 \\
(0,125)\end{array}$ & $\begin{array}{c}-0,602 \\
(-2,250)\end{array}$ & $\begin{array}{c}2,847 \\
(1,985)^{* *}\end{array}$ & $\begin{array}{c}3,510 \\
(2,417)^{*}\end{array}$ \\
\hline$F$ & 616,6 & 467,1 & 218,5 & 413,589 & 473,0 & 312,5 & 342,7 & 628,1 & 243,0 \\
\hline$R^{2}$ & 0,9610 & 0,9125 & 0,8964 & 0,9008 & 0,8763 & 0,9144 & 0,9737 & 0,9824 & 0,9025 \\
\hline $\begin{array}{l}\text { Durbin- } \\
\text { Watson }\end{array}$ & 1,139 & 1,786 & 1,606 & 1,951 & 1,655 & 1,842 & 1,766 & 2,512 & 1,528 \\
\hline $\mathrm{N}^{\circ}$ obs. & 105 & 184 & 106 & 187 & 272 & 122 & 42 & 50 & 110 \\
\hline
\end{tabular}

* nível de significância de $1 \%$

** nível de significância de $5 \%$

Partindo da hipótese de que os modelos foram corretamente especificados, de acordo com a Tabela 9, a estatística $F$ de todas as regressões apresentou um valor bastante elevado, o que indica que ao menos um dos coeficientes estimados é diferente de zero, o que, por consequiência, aponta que ao menos uma das variáveis explicativas selecionadas é significativa para o modelo.

A significância dos testes $F$ era esperada, uma vez que ao menos a variável distância tem uma relação bastante clara com os valores fixados para os fretes. Portanto, não serão tecidas novas análises sobre o teste $F$, evitando-se a redundância dos comentários. 
Para todas as equações, os coeficientes de determinação $R^{2}$ também foram altos, variando de 0,8763 , para as movimentações com origem no estado de Mato Grosso em 1999, até 0,9824, para a equação do Paraná, ano de 1999.

Esses resultados mostram que as variáveis utilizadas explicam mais do que $85 \%$ das variações nos valores observados, o que é bastante representativo, trazendo indícios da boa especificação dos modelos.

As estatísticas Durbin-Watson indicaram que, das nove equações especificadas para representar as movimentações de soja com origem em Goiás, Mato Grosso e Paraná durante a safra, três modelos: Goiás (1998); Mato Grosso (1999) e Paraná (2000), apresentaram resultados que contribuem para que se rejeite a hipótese nula de evidência de autocorrelação positiva de primeira ordem entre os resíduos a um nível de significância de 5\%. Já para as equações que representam as safras de Goiás em 1999 e 2000, e Paraná em 1999, os resultados ficaram dentro da zona de indecisão, diferentemente das equações que representaram as safras de Mato Grosso em 1998 e 2000, e Paraná em 1998, em que a análise dos resultados não permite que se rejeite a hipótese nula de existência de autocorrelação de primeira ordem dos resíduos para o mesmo nível de significância.

De modo geral, percebe-se pela análise da Tabela 9 que fatores mais facilmente avaliados pelos demandantes, como os gastos adicionais com combustível nos percursos mais longos, representados pela variável $D I S T A N C I A_{i j}$, ou os gastos com pedágios, são normalmente considerados na definição dos fretes durante a safra, independentemente da origem da carga ou do ano da observação.

Percebe-se, assim, que a variável $D I S T A N C I A_{i j}$ foi significativa em todas as equações, e a variável $P E D A G I O_{i j}$ foi significativa em oito das nove equações estimadas.

Analisando todos os coeficientes calculados para a variável DISTANCIA $i j$, expostos na Tabela 9, percebe-se que para todos os estados estudados e para todos os anos (1998 a 2000), os coeficientes calculados apresentaram ordens de grandeza bastante similares, mesmo que estatisticamente diferentes, o que demonstra que 
independente de outros fatores que possam influenciar a fixação dos preços dos fretes, a variável distância tem um peso bastante similar em todos os casos.

Em valores reais isso significa que, para cada quilômetro percorrido, esse fator agregou ao preço do frete o montante de $R \$ 0,034$, no caso das movimentações com origem no Mato Grosso, durante a safra de 2000, até $\mathrm{R} \$ 0,054$, como nas movimentações com origem no Paraná, nas safras de 1998 e 1999.

No caso específico de Goiás, como esperado, os coeficientes estimados para a variável $D I S T A N C I A_{i j}$ também foram positivos e significativos. A estimação desses coeficientes apresentou valores um tanto semelhantes para essas três equações, 0,040 , 0,040 e 0,035 para os anos de 1998, 1999 a 2000, respectivamente, sinalizando, a princípio, que aparentemente não houve uma diferença acentuada na definição dos fretes entre esses anos, em se tratando de cargas originadas em Goiás.

Por outro lado, as equações que representaram as movimentações nos períodos de safra com origem em Goiás nos anos de 1998 e 1999 apresentaram coeficientes exatamente iguais $(0,040)$ e maiores que aquele estimado para o ano de $2000(0,035)$, o que pode ter ocorrido em função das oscilações da demanda por serviços de transporte naqueles anos, e que proporcionou diferentes graus de poder de barganha entre os agentes nos diferentes anos, reduzindo ou elevando a participação da influência de certos fatores, como das condições de tráfego das rodovias, sobre os preços dos fretes praticados.

No modelo especificado para as movimentações com origem em Goiás no ano de 1998, por exemplo, o coeficiente da variável $V I A_{i j}$ foi significativo e igual a $-3,068$, o que não ocorreu nos modelos especificados para as duas safras subseqüentes.

Esse fenômeno indica que, durante o ano de 1998, os transportadores que partiram de Goiás tendiam a cobrar menos para efetuar movimentações através de vias em boas condições de utilização, o que, diferentemente do que muitos defendem, demonstra que o transportador tem consciência dos maiores custos operacionais que decorrem da utilização de vias mal conservadas, estando dispostos a priorizar os melhores percursos. 
Entretanto, o que parece ocorrer muitas vezes é que, nos momentos em que outros fatores reduzem as margens de lucro, tal como o início da cobrança de pedágios, os transportadores se sentem menos confortáveis em considerar fatores menos palpáveis, como a diferença de custos operacionais decorrentes da utilização de vias em diferentes estados de conservação.

Junta-se a isso o fato de que, para as movimentações com origem em Goiás no período analisado, a variável $P E D A G I O_{i j}$ foi significativa para os três anos de safra, sendo que os coeficientes estimados para essa variável foram positivos, o que indica uma tendência dos transportadores a cobrar diferentemente nas movimentações em estradas com pedágios, em comparação com aquelas que não apresentam essas praças de cobrança, implicando fretes mais elevados para transitar em estradas pedagiadas.

É interessante notar que, apesar da relevância da variável $P E D A G I O_{i j}$ para qualquer um dos três períodos, a grandeza do coeficiente estimado para o ano de 1998, 1,008 , é diferente dos valores dos coeficientes estimados para os anos de 1999 e 2000 , que foram 1,425 e 1,165 respectivamente.

Essa característica pode estar associada ao fato de que o processo de concessão de estradas começou a ser mais intenso a partir de 1997, sendo que, com exceção do estado de São Paulo, onde o governo mantinha diversas praças antes de privatizar as rodovias, a maioria dos estados apresentava um número reduzido de postos de cobrança de pedágio.

Desta forma, em 1998, grande parte das concessões era incipiente, sendo que algumas praças de pedágio, hoje em operação, ou ainda não estavam em funcionamento naquela época ou observavam menores tarifas que as atuais. Esses e outros fatores podem ter contribuído para que a importância da existência de pedágio tenha sido menor em 1998, o que se reflete nos coeficientes estimados.

Essa pressão relativamente menor dos pedágios no ano de 1998 pode também ter contribuído para que os transportadores goianos tivessem uma certa margem para considerar outros fatores para definição dos valores dos fretes, o que está sinalizado pela significância do coeficiente estimado para a variável $V I A_{i j}$ apenas em 1998. 
Ainda com relação às movimentações com origem no estado de Goiás, durante as safras de 1998 a 2000 , percebe-se que, mesmo considerando que os valores encontrados para os coeficientes da variável DISTANCIA $A_{i j}$ sejam similares, as equações são estatisticamente diferentes, sendo que a equação estimada para o ano de 1998 tem uma composição mais complexa que aquelas estimadas para os anos de 1999 e 2000, isto é, o mecanismo de definição dos valores dos fretes em 1998 obedeciam a regras bastante distintas daquelas consideradas nos anos de 1999 e 2000, uma vez que outros fatores, como o tipo da via utilizada, eram relevantes.

Com referência às equações estimadas para as movimentações com origem no estado de Mato Grosso, para todos os três anos (1998, 1999 e 2000), os coeficientes de determinação encontrados também foram altos, sendo equivalentes a $0,9008,0,8763 \mathrm{e}$ 0,9144, respectivamente, o que indica que no caso de 1998, por exemplo, as variáveis utilizadas explicam cerca de $90 \%$ das variações nos valores dos fretes observados.

Com relação à variável $D_{I S T A N C L A_{i j}}$, a mesma foi representativa nos três modelos, sendo que os coeficientes calculados para os três anos foram eqüivalentes a 0,039 (1998), 0,036 (1999) e 0,034 (2000). Isto indica que em 1999, por exemplo, os transportadores cobraram, em média, cerca de $\mathrm{R} \$ 0,036$, em termos reais, por quilômetro adicional rodado, todo o resto mantido constante.

Observa-se, assim, que a variável DISTANCIA $A_{i j}$ foi considerada de maneira bastante similar, durante as safras de 1999 e 2000, para a composição dos fretes praticados para o transporte de soja a granel com origem no estado de Mato Grosso.

Para os três modelos (1998, 1999 e 2000) estimados para as movimentações de safra com origem no estado de Mato Grosso, a variável $P E D A G I O_{i j}$ foi significativa e apresentou uma relação direta com a variável dependente, de forma similar a Goiás, o que indica que o valor do frete tende a ser relativamente maior tanto maior seja o número de pedágios na via utilizada. Para essa variável, os coeficientes encontrados nas equações geradas para o estado de Mato Grosso foram iguais a 0,938 em 1998, 1,596 para 1999 e 1,817 para 2000.

Assim, ao analisar-se o conjunto de dados especificados para as movimentações com origem no estado de Mato Grosso, a variável $P E D A G I O_{i j}$ atuou de maneira distinta 
na safra de 1998, em relação às safras de 1999 e 2000, sendo que o coeficiente calculado para os dois últimos anos foi maior, fenômeno que pode estar relacionado ao aumento do número das praças de pedágios nos últimos anos, conforme citado anteriormente.

Uma similaridade entre os mecanismos de formação dos valores de frete praticados nos dois estados (GO e MT) é a relevância das variáveis que representam a distância percorrida $\left(D_{I S T A N C L A_{i j}}\right)$ e o número de praças de pedágios $\left(P E D A G I O_{i j}\right)$. Isto se dá pelo fato de que foram as únicas variáveis representativas entre os itens considerados no modelo, para todos os três anos, em detrimento de outras variáveis, como as associadas à possibilidade de se obter carga de retorno nos percursos com destino aos portos e às condições das vias utilizadas, exceto para as movimentações com origem em Goiás na safra de 1998, em que a variável $V I A_{i j}$ mostrou-se significativa.

Por outro lado, o fato da variável $R E T O R N O_{j}$ não se mostrar significativa em nenhum dos anos para os estados de MT e GO mostra, primeiramente, que os portos não são indicados como destinos diferenciados quanto à possibilidade de se conseguir carga de retorno durante a safra. Com isto, assume-se que os transportadores que partem de Goiás e Mato Grosso nessa época do ano são indiferentes quanto ao destino das movimentações que efetuam, podendo envolver os portos ou não.

Esse resultado não indica necessariamente que os transportadores desconsideram a possibilidade de se obter carga de retorno na composição dos preços de frete, mas apenas que as cidades portuárias não são apontadas como possíveis pontos de obtenção dessas cargas. Pode ocorrer talvez que outros destinos sejam identificados por essa característica, fenômeno que não pôde ser melhor explorado pela especificação do modelo utilizado neste trabalho.

Os resultados das equações estimadas para as movimentações de soja, nos períodos de safra de 1998 a 2000, no estado do Paraná, assim como no caso dos outros dois estados (GO e MT), apresentaram coeficientes de determinação $R^{2}$ bastante representativos: 0,9737 (1998), 0,9824 (1999) e 0,9025 (2000), o que reitera a boa especificação dos modelos. Esses resultados mostram que, para a safra de 1998, cerca de 97\% das variações nos valores utilizados são explicados pelo modelo proposto, sendo 
que esse percentual é equivalente a $98 \%$ para a safra de 1999 e $90 \%$ para a safra de 2000 .

Como esperado, os coeficientes da variável DISTANCIA $A_{i j}$ também foram significativos e positivos, apresentando valores iguais a 0,054 (1998), 0,054 (1999) e $0,046(2000)$.

Nota-se que, diferentemente do que ocorre com as movimentações com origem nos estados de Goiás e Mato Grosso, em que os resultados obtidos mostraram uma certa similaridade com relação às principais variáveis que influenciam a definição dos preços dos fretes, e na relação (direta ou indireta) que esses fatores têm com a variável dependente, no caso do Paraná, observaram-se algumas particularidades substanciais.

Isso ocorre principalmente porque as observações utilizadas para o estado do Paraná são essencialmente intra-estaduais, fazendo com que os transportadores desse estado sejam mais sensíveis às ocorrências que possam vir a influenciar a matriz de transporte estadual. Já no caso dos estados de Mato Grosso e de Goiás, a maior parcela de movimentações interestaduais faz com que os fatores que influenciam a atividade de transporte em determinado ponto do país, como por exemplo, uma greve de estivadores no porto de Santos, tenha um efeito menor sobre os preços praticados nos fretes com origem nesses estados.

Diferentemente do observado nos estados de MT e GO, no caso do Paraná, os coeficientes gerados para a variável $V I A_{i j}$ nos anos de safra de 1998 e 2000 foram significativos a um nível inferior a $1 \%$.

Os coeficientes gerados para a variável $V I A_{i j}$ nas equações estimadas para o Paraná, quando significativos (safra de 1998 e 2000), apresentaram valores positivos (seria mais razoável o sinal negativo, tal como observado em 1998 para GO), o que indicaria, a princípio, que existe uma relação direta entre os valores dos fretes rodoviários para transporte de soja com origem no Paraná (durante a safra) e o tipo de via utilizada, sendo que os transportadores tenderiam a cobrar mais para trafegar nas melhores vias.

Uma análise mais profunda revelou, no entanto, que a baixa representatividade desse fator nessas amostras pode ter interferido nos resultados. Isto porque, no caso das 
observações relativas a 1998, apenas duas observações apresentam valor zero para a variável $V I A_{i j}$, ou seja, menos que $5 \%$ do total de dados, ocorrendo algo similar para conjunto de dados do ano 2000.

Ainda conforme comentários anteriores, as movimentações com origem no Paraná são quase que exclusivamente intra-estaduais, sendo que as principais rodovias do estado são consideradas em boas condições de tráfego.

No caso do conjunto de dados de 2000 , as observações que apresentam valor zero para a variável $V I A_{i j}$ são apenas dez, representando, portanto, menos que $10 \%$ do total de dados. Além disto, sete dessas observações referem-se a percursos inferiores a $50 \mathrm{~km}$, relacionados a ligações que envolvem a cidade de Maringá e cidades vizinhas, o que justifica que esses percursos tenham valores relativamente menores que os demais, em função dos ganhos de produtividade decorrentes do maior número possível de viagens que esses transportadores podem fazer ao dia, distorcendo o significado da variável proposta.

Por outro lado, a representatividade da variável $V I A_{i j}$ nos modelos especificados para as movimentações com origem no estado do Paraná para os anos de 1998 e 2000 , 4,882 e 2,347, respectivamente, pode estar associada ao fato de que, em sua maioria absoluta, as movimentações com origem nesse estado são efetuadas através de vias classificadas no presente trabalho como boas (cerca de $90 \%$ das observações), sendo que essas rodovias são pedagiadas e ligam os principais centros urbanos.

Assim, mesmo que a utilização de boas rodovias possa reduzir os custos operacionais de transporte, no caso do Paraná, essa utilização pode estar sendo interpretada como a possibilidade de elevação de outros custos (alimentação, maior exposição a acidentes etc.), tráfego, assaltos e outros, justificando a relação direta entre os coeficientes calculados e a variável dependente (coeficientes positivos).

Ainda para o estado do Paraná, de acordo com a Tabela 9, para a equação gerada para as movimentações da safra de 1998, diferentemente dos demais anos, a variável $P E D A G I O_{i j}$ aparece como significativa, sendo que o coeficiente estimado é equivalente $\mathrm{a}-1,175$. 
A relação inversa dessa variável com a variável explicada pode ter por justificativa um fenômeno já abordado no presente trabalho. Como pode ser observado na Tabela $B$, no Apêndice 1 , as rodovias no estado do Paraná foram privatizadas simultaneamente no final do ano de 1997, sendo que o processo de implementação de praças de pedágio nessas rodovias foi gradativo. Muitas praças foram construídas durante o ano de 1998 entrando em operação apenas nos últimos meses daquele ano.

Desta forma, pode-se inferir que, durante a safra de 1998, representada por observações referentes aos meses de março e abril (início do ano), não tenha sido afetada diretamente pela existência de pedágios.

Outra particularidade dos resultados obtidos para o estado do Paraná é que as equações que representam as safras de 1999 e 2000 apresentaram para a variável RETORNO $O_{j}$, coeficientes equivalentes a 2,847 e 3,510, respectivamente, o que indica a existência de uma relação direta entre os fretes praticados no estado nesses períodos e as cargas com destino aos portos.

Lembrando que a soja com origem no Paraná dirigida à exportação tem como destino quase que exclusivo o porto de Paranaguá, tal resultado indica que os transportadores, em 1999 e 2000, tenderam a cobrar um adicional de cerca de $R \$ 2,847 / \mathrm{t}$ (1999) e R\$ 3,510/t (2000), em termos reais, para transportar a soja para esse destino. Esse fato pode ser explicado pelo crescimento da produção de soja nos últimos anos e a canalização de boa parte da produção para o mercado externo, o que tem sobrecarregado a capacidade de embarque dos portos, especialmente do porto de Paranaguá, principal porto de embarque de grãos do Brasil.

Segundo Baumer (2001), mesmo que tenham sido investidos cerca de R\$13 milhões no porto de Paranaguá durante o ano de 2000, o que permitiu a ampliação em $50 \%$ da capacidade de embarque (de $6 \mathrm{mil}$ t/hora em 2000 para $9 \mathrm{mil} \mathrm{t} /$ hora em 2001), as filas de espera para que os caminhoneiros possam descarregar ultrapassam 50 quilômetros durante a safra, mesmo com o porto trabalhando 24 horas por dia.

De acordo com Stuani (2001), as filas de caminhões no dia 10 de abril de 2001, no porto de Paranaguá, ultrapassavam cem quilômetros, sendo que, segundo a autora, as exportações pelo porto cresceram $50 \%$ em relação ao ano anterior (também em função 
da greve de Santos), o que reforça a tendência de canalização das exportações nos últimos anos e que, mesmo com investimentos, o aumento da demanda por embarques tem sido maior que os ganhos de eficiência.

Assim, é compreensível que os transportadores paranaenses tenham requerido melhores fretes para transportar a soja com destino a Paranaguá, pois a maior demora para efetuar o descarregamento dos grãos reduz a produtividade na atividade de transporte.

Esse efeito não foi captado nos demais estados, possivelmente em função da maior diversidade de destinos das cargas com origem nos estados de Goiás e Mato Grosso e, conseqüentemente, da menor dependência desses estados dos fretes com destino a Paranaguá.

De qualquer forma, a maior diversidade nas equações que representaram as movimentações nos períodos de safra sob estudo com origem no estado do Paraná indica que os transportadores que atuam nesse estado são mais sensíveis às mudanças no ambiente em que atuam que seus companheiros que movimentam soja a granel com origem nos estados de Goiás e Mato Grosso.

\subsubsection{Estimativas para os períodos de entressafra}

A Tabela 10 apresenta os resultados obtidos na estimação dos modelos relativos às movimentações de soja durante as entressafras de 1998/1999, 1999/2000 e 2000/2001, para cada um dos estados de origem estudados.

Similarmente ao que se observou para os modelos referentes aos períodos de safra (vide Tabela 9), a maior parte dos coeficientes significativos apresentou testes $t$ a um nível inferior a $1 \%$, o que significa a existência de uma possibilidade quase nula de que os coeficientes estimados possam ser iguais a zero. 
Tabela 10. Principais resultados dos modelos de estimação do valor do frete praticado para o transporte rodoviário de soja a granel, com origem nos estados de Goiás, Mato Grosso e Paraná, nas entressafras de 1998/1999, 1999/2000 e $2000 / 2001$.

\begin{tabular}{|c|c|c|c|c|c|c|c|c|c|}
\hline $\begin{array}{l}\text { Variável/ } \\
\text { Estatísticas }\end{array}$ & $\begin{array}{c}\text { GO } \\
98 / 99\end{array}$ & $\begin{array}{c}\text { GO } \\
99 / 00\end{array}$ & $\begin{array}{c}\text { GO } \\
00 / 01\end{array}$ & $\begin{array}{c}\text { MT } \\
98 / 99\end{array}$ & $\begin{array}{c}\text { MT } \\
99 / 00\end{array}$ & $\begin{array}{c}\text { MT } \\
00 / 01\end{array}$ & $\begin{array}{c}\text { PR } \\
98 / 99\end{array}$ & $\begin{array}{c}\text { PR } \\
99 / 00\end{array}$ & $\begin{array}{c}\text { PR } \\
00 / 01\end{array}$ \\
\hline Constante & $\begin{array}{c}2,456 \\
(6,746)^{*}\end{array}$ & $\begin{array}{c}2,708 \\
(5,583)^{*}\end{array}$ & $\begin{array}{c}4,431 \\
(13,622)^{*}\end{array}$ & $\begin{array}{c}11,067 \\
(10,491)^{*}\end{array}$ & $\begin{array}{c}9,735 \\
(9,863)^{*}\end{array}$ & $\begin{array}{c}4,659 \\
(3,473)^{*}\end{array}$ & $\begin{array}{c}-6494 \\
(-26,256)^{*}\end{array}$ & $\begin{array}{c}-1,881 \\
(-6,690)^{*}\end{array}$ & $\begin{array}{c}2,088 \\
(1,346)\end{array}$ \\
\hline Distância & $\begin{array}{c}0,046 \\
(35,661)^{*}\end{array}$ & $\begin{array}{c}0,046 \\
(25,817)^{*}\end{array}$ & $\begin{array}{c}0,040 \\
(33,567)^{*}\end{array}$ & $\begin{array}{c}0,031 \\
(29,053)^{*}\end{array}$ & $\begin{array}{c}0,031 \\
(19,273)^{*}\end{array}$ & $\begin{array}{c}0,032 \\
(26,950)^{*}\end{array}$ & $\begin{array}{c}0,054 \\
(79,487)^{*}\end{array}$ & $\begin{array}{c}0,045 \\
(102,276)^{*}\end{array}$ & $\begin{array}{c}0,044 \\
(73,442)^{*}\end{array}$ \\
\hline Via & $\begin{array}{c}-0,808 \\
(-1,134)\end{array}$ & $\begin{array}{c}-0,655 \\
(-0,551)\end{array}$ & $\begin{array}{c}0,707 \\
(1,151)\end{array}$ & $\begin{array}{l}-1,994 \\
(-1,932)\end{array}$ & $\begin{array}{r}0,330 \\
(0,287)\end{array}$ & $\begin{array}{c}2,810 \\
(1,944)\end{array}$ & $\begin{array}{c}11,355 \\
(5,589)^{*}\end{array}$ & $\begin{array}{c}7,257 \\
(3,709)^{*}\end{array}$ & $\begin{array}{c}-0,421 \\
(-0,235)\end{array}$ \\
\hline Pedágio & $\begin{array}{c}-0,440 \\
(-1,042)\end{array}$ & $\begin{array}{c}-0,129 \\
(-0,318)\end{array}$ & $\begin{array}{c}0,416 \\
(2,364)^{*}\end{array}$ & $\begin{array}{c}0,354 \\
(0,846)\end{array}$ & $\begin{array}{c}1,742 \\
(3,747)^{*}\end{array}$ & $\begin{array}{c}0,963 \\
(1,571)\end{array}$ & $\begin{array}{c}-1,423 \\
(-2,094)\end{array}$ & $\begin{array}{c}-0,363 \\
(-0,707)\end{array}$ & $\begin{array}{c}0,139 \\
(0,549)\end{array}$ \\
\hline Retorno & $\begin{array}{l}1,260 \\
(0,433)\end{array}$ & $\begin{array}{c}-2,018 \\
(-0,502)\end{array}$ & $\begin{array}{c}-0,950 \\
(-0,752)\end{array}$ & $\begin{array}{c}-1,408 \\
(-0,526)\end{array}$ & $\begin{array}{c}-2,866 \\
(-1,551)\end{array}$ & $\begin{array}{c}4,375 \\
(0,919)\end{array}$ & $\begin{array}{c}1,788 \\
(0,709)\end{array}$ & $\begin{array}{c}-0,058 \\
(-0,045)\end{array}$ & $\begin{array}{c}-0,492 \\
(-0,397)\end{array}$ \\
\hline$F$ & 858,7 & 407,3 & 852,0 & 435,9 & 690,7 & 189,2 & 394,5 & 710,4 & 265,1 \\
\hline$R^{2}$ & 0,9586 & 0,9520 & 0,9687 & 0,9488 & 0,9725 & 0,9164 & 0,9887 & 0,9926 & 0,9532 \\
\hline $\begin{array}{l}\text { Durbin- } \\
\text { Watson }\end{array}$ & 0,982 & 1,553 & 1,387 & 1,419 & 1,563 & 1,966 & 1,891 & 1,400 & 1,873 \\
\hline $\mathrm{N}^{\circ}$ obs. & 153 & 87 & 115 & 99 & 83 & 74 & 23 & 22 & 57 \\
\hline
\end{tabular}

* nível de significância de $1 \%$

Conforme mencionado, para todos os modelos especificados foram analisadas as estatísticas Durbin-Watson (vide penúltima linha da Tabela 10), sendo que para as equações que representaram as movimentações de entressafra no estado de Goiás em 1998/1999 e 2000/2001, Mato Grosso em 1998/1999 e 1999/2000 e Paraná em 1999/2000, os testes indicaram que pode-se rejeitar a hipótese de existência de autocorrelação positiva de primeira ordem entre os resíduos a um nível de significância de 5\%. Já para as equações de entressafra de Goiás 1999/2000 e Paraná 1999/2000, os resultados ficaram dentro da zona de indecisão, ou melhor, são inconclusivos, para o mesmo nível de significância, diferentemente dos resultados obtidos para as equações de entressafra das cargas com origem no estado do Mato Grosso em 2000/2001, Paraná 1998/1999 e 2000/2001 que indicaram que não se pode rejeitar a hipótese de autocorrelação de primeira ordem dos resíduos, ao mesmo nível de significância. 
Diferentemente dos resultados obtidos para o período de safra, a Tabela 10 mostra que as observações selecionadas para representar a entressafra apresentaram a influência de um leque menos diversificado de fatores. A maioria das equações estimadas apresentou a significância quase exclusiva da distância na composição dos valores dos fretes.

Este resultado indica que, independentemente do estado de origem e do ano estudado, a brusca redução na demanda por serviços de transportes rodoviários de cargas, durante a entressafra da soja, impede que os transportadores incluam nos preços praticados a influência de outros fatores importantes na atividade que são considerados em situações menos adversas, como a existência de praças de pedágio.

Como pode ser observado na Tabela 10, as três equações que representam os períodos de entressafra para a soja movimentada com origem em Goiás apresentaram a variável DISTANCIA $A_{i j}$ como representativa para todos os anos, sendo os coeficientes calculados iguais a 0,046 (1998/1999), 0,046 (1999/2000) e 0,040 (2000/2001).

Já para os modelos estimados para o estado de Mato Grosso, a variável DISTANCIA $i j$, apresentou coeficientes iguais a 0,031 para 1998/1999, 0,031 para 1999/2000 e 0,032 para 2000/2001.

Vale ressaltar que os coeficientes calculados para a variável $D I S T A N C I A_{i j}$, nos períodos de safra para as movimentações originadas em Goiás, foram menores que os mesmos coeficientes calculados nas entressafras do mesmo ano, ou seja, os coeficientes da variável $D I S T A N C I A_{i j}$ para a safra de 1998 e 1999 foram iguais a 0,040, e para 2000, 0,035, enquanto que nas entressafras de 1998/1999 e 1999/2000, os coeficientes calculados foram iguais a 0,046 , e 0,040 na entressafra de 2000/2001.

No caso do Mato Grosso a situação é inversa. Os coeficientes calculados para a variável $D I S T A N C I A_{i j}$, durante a entressafra, são todos menores que os respectivos coeficientes de safra. Para as cargas originadas em Mato Grosso, os coeficientes calculados para essa variável foram 0,031 (1998/1999 e 1999/2000) e 0,032 (2000/2001); já para a safra, esses mesmos coeficientes foram equivalentes a 0,039 (1998), 0,036 (1999) e 0,034 (2000). 
Isso pode indicar, no caso de Goiás, que com a redução da demanda por transporte no período de entressafra e a conseqüente diminuição da influência de outros fatores na composição dos fretes praticados, a tendência de redução nos preços dos fretes seja em parte compensada pela elevação da importância da distância do percurso sobre os valores firmados.

Por outro lado, uma redução mais intensa da demanda regional por transporte no estado do Mato Grosso pode ter contribuído não somente para a minimização, na entressafra, da influência de variáveis relevantes como o pedágio como também para a redução dos preços praticados através da redução da influência da distância entre origem e destino sobre os fretes.

Enfim, o que se observa é que a sazonalidade da demanda por serviços de transportes rodoviários de grãos teve uma influência direta sobre a composição de variáveis na definição dos preços dos fretes praticados, o que pode ser observado com a análise do comportamento da variável $P E D A G I O_{i j}$, por exemplo. Diferentemente do que ocorreu para os modelos especificados para o período de safra, durante a entressafra, a variável $P E D A G I O_{i j}$ foi significativa apenas para as movimentações com origem no estado de Mato Grosso no período de 1999/2000 e com origem em Goiás, na entressafra de 2000/2001.

Para as cargas originadas do Paraná, é interessante observar o comportamento da variável DISTANCIA $A_{i j}$ ao longo do tempo. Para esse estado, os coeficientes estimados para essa variável nas safras de 1998 e 1999 e para a entressafra de 1998/1999 foram iguais a 0,054 , o que indica que, durante metade do período sob estudo, para cada quilômetro de percurso com origem no Paraná, foi adicionado em média $R \$ 0,054$ ao frete, em termos reais, todo o resto mantido constante.

Por outro lado, a partir da entressafra de 1999, os coeficientes estimados para essa variável foram 0,045 para a entressafra de 1999/2000, 0,046 para a safra de 2000 e 0,044 para a entressafra de 2000/2001, sinalizando uma mudança no comportamento do preço do frete, de forma que a partir da entressafra de 1999/2000, a distância percorrida passou a contribuir menos, em termos reais, na composição dos valores dos fretes rodoviários de soja com origem no Paraná. 
Por fim, as equações que representam as entressafras de 1998/1999 e 1999/2000 no Paraná indicaram como representativos, a um nível de significância de $1 \%$, os coeficientes calculados para a variável $V I A_{i j}, 11,355$ e 7,257 respectivamente, o que reafirma o comportamento encontrado para as equações que representaram os períodos de safra nos anos de 1998 e 2000 para esse mesmo estado.

Esse fenômeno indica que existem alguns fatores, como os apresentados anteriormente, associados aos principais corredores de transporte rodoviário do estado, que implicam uma tarifa mais elevada para os destinos que utilizam essas vias. 


\section{CONCLUSÕES}

O presente trabalho procurou identificar a influência de certos fatores na composição dos valores dos fretes praticados para transporte de cargas agricolas no Brasil, com foco na soja em grãos.

A revisão bibliográfica mostrou que fatores como: distância percorrida, possibilidade de obtenção de carga de retorno, sazonalidade da demanda por transporte, especificidade da carga transportada e do veículo utilizado, vias utilizadas, pedágios e fiscalização, aspectos geográficos (preferência por determinados percursos), prazo de entrega, tempo de carga e descarga, perdas e avarias podem influenciar nessa composição.

A literatura consultada indicou que vários autores têm estudado o assunto, utilizando-se principalmente de abordagens econométricas.

Valendo-se de um modelo de regressão linear múltipla, estimado pelo método dos mínimos quadrados ordinários, procurou-se identificar a influência de alguns desses fatores para a composição dos fretes rodoviários de soja a granel com origem nos estados de Goiás, Mato Grosso e Paraná, entre 1998 e 2001.

Os resultados obtidos indicam que, para os conjuntos de dados utilizados, referentes ao transporte de soja a granel com origem nos estados de Goiás, Mato Grosso e Paraná, durante as safras de 1998 a 2000 e as entressafras de 1998/1999 a 2000/2001, a distância percorrida foi um fator fundamental para a composição dos preços dos fretes praticados, independentemente do período e origem das cargas.

Porém, o valor do frete nesses percursos, em alguns momentos, em maior ou menor grau, foi influenciado por fatores secundários, tais como: a existência de praças 
de pedágios em algumas rodovias, o tempo de descarregamento nos portos, sazonalidade da demanda por transporte $\mathrm{e}$ as condições das vias utilizadas. Fatores como a especificidade da carga transportada e do veículo utilizado, perdas e avarias, entre outros, não puderam ser avaliados.

A influência da sazonalidade da demanda por serviços de transporte de soja a granel ficou evidente nas diferenças das especificações das equações propostas para os períodos de safra e as equações propostas para os períodos de entressafra.

No caso das cargas com origem em Goiás, por exemplo, a condição das rodovias parece ter sido um diferencial durante a safra de 1998, o que sinaliza que os transportadores estão atentos às diferenças de custos operacionais decorrentes do tráfego em vias com estados de conservação diferentes. Talvez em função do aumento das praças de pedágios após 1998, devido às concessões de rodovias brasileiras, essa preferência não foi expressa nas safras subseqüentes, diferentemente do próprio pedágio que, no caso de Goiás, cresceu de importância na determinação dos valores dos fretes, bem como no estado de Mato Grosso, nas observações referentes às safras de 1998 a 2000, e no estado do Paraná, na safra de 1998.

Como durante 1999 e 2000 os valores dos fretes sofreram impactos da elevação do preço do óleo diesel e da implantação de um número crescente de praças de pedágios, os transportadores podem ter identificado um ambiente menos favorável para expressar preferências menos evidentes, como a escolha por percursos com melhores estradas.

Por outro lado, a utilização de rodovias em boas condições pode sinalizar acréscimos nos custos de transporte, uma vez que essas vias podem estar associadas a grandes centros urbanos, traduzindo-se em maiores gastos com alimentação, maior exposição a acidentes e outros. Esse fenômeno pôde ser observado através da análise das equações que representaram as movimentações com origem no estado do Paraná uma vez que, na maioria das equações estimadas, foi indicado que os transportadores cobram um adicional para utilizarem essas rodovias.

Outra importante conclusão é que, mesmo que as variáveis relevantes nos modelos especificados sejam muitas vezes similares, a atividade de transporte é bastante regionalizada, sendo que existem diferenças qualitativas entre os mercados de 
transportes de Goiás, Mato Grosso e Paraná, o que justifica a realização de estudos separados para cada um desses mercados.

O mercado do Paraná foi o que se mostrou mais sensível às variáveis estudadas, o que indica que os transportadores que atuam naquele estado transferem para os valores dos fretes praticados, com maior freqüência, suas expectativas em relação aos fatores estudados para o mercado de transporte de soja a granel.

As diferentes interações entre demanda e oferta de serviços de transportes para granéis sólidos agrícolas, ao longo do tempo, parecem contribuir também para que alguns fatores tenham pesos diferentes na composição dos fretes em cada período, o que demonstra que a própria economia define a relevância direta desses fatores sobre os fretes praticados, justificando também que esses efeitos sejam tratados diferentemente ano a ano.

$O$ presente trabalho também revelou que os portos, principalmente o de Paranaguá, não foram identificados como possíveis pontos de obtenção de cargas de retorno, mas sim como destinos preteridos em função da morosidade no descarregamento de grãos, o que foi captado pela equação estimada para as movimentações de soja com origem no estado do Paraná na safra de 2000.

Esse resultado traz à tona mais uma faceta do chamado Custo Brasil, ao onerar os produtos nacionais com destino à exportação em função das deficiências da matriz de transportes do país, tornando os produtos brasileiros menos competitivos no mercado internacional.

Destaca-se também que, nos períodos de entressafra, a distância percorrida foi indicada como o principal determinante nos preços dos fretes, sendo que, de modo geral, outros fatores parecem ter sido relevados. Isto demonstra que a necessidade da manutenção de uma frota de caminhões suficiente para o escoamento da produção, durante a safra, parece contribuir para que haja uma capacidade ociosa durante a entressafra de grãos, o que implica impacto direto na composição dos preços dos fretes.

Portanto, o transporte rodoviário de soja a granel no Brasil vem sendo influenciado por diferentes fatores entre 1998 e 2001, tais como a existência de praças de pedágio, condições de tráfego das rodovias utilizadas e morosidade de descargas nos 
portos, bem como a própria distância percorrida, sendo que a dinâmica da economia é decisiva para a definição da influência desses fatores sobre os preços dos fretes.

Conclui-se, assim, que esses fatores podem acarretar impactos reais sobre a lucratividade da atividade, sendo que o acirramento da concorrência em meses de demanda escassa pode impedir que esses efeitos sejam repassados integralmente aos custos, tornando os lucros dos transportadores também sazonais.

O trabalho apresentado não pretende esgotar a discussão sobre o tema, mas apenas destacar sua importância para um melhor entendimento da atividade de transporte de cargas agrícolas no Brasil, através de uma abordagem ainda não exaustivamente explorada em trabalhos científicos similares no Brasil.

Assim, trabalhos que venham a discutir a influência desses e de outros fatores sobre os fretes praticados nos diversos segmentos agropecuários, bem como aprofundar as questões levantadas neste trabalho, tais como o custo de transporte rodoviário associado à morosidade dos serviços portuários, a influência da privatização das rodovias sobre os fretes praticados, ou questões associadas à subutilização da frota brasileira dessa categoria de caminhões durante a entressafra de soja, entre outros, deverão contribuir sobremaneira para uma melhor gestão do setor de transportes de cargas no Brasil. 


\section{REFERÊNCIAS BIBLIOGRÁFICAS}

AGÊNCIA NACIONAL DE PETRÓLEO. Anuário Estatístico da Indústria Brasileira de Petróleo. www.anp.gov.br (23/05/01).

ALLEN, B.; LIU, D. Service quality and motor carrier costs: an empirical analysis. The Review of Economics ans Statistics, v.77, n.3, p.499-509, Aug.1995.

AMERICAN SHIPPER. Diesel fuel relief sought in Congress. Jacksonville, 2000.104p.

ANUÁRIO ESTATÍSTICO DE TRANSPORTES 1996. Brasília: Ministério dos Transportes, 1996. v.23.

ANUÁRIO ESTATÍSTICO DE TRANSPORTES 2000. Brasília: Ministério dos Transportes, 2000. v.27,p.343.

ASSOCIAÇÃO BRASILEIRA DE CONCESSIONÁRIAS DE RODOVIAS. Associação Brasileira de concessionárias de Rodovias. http:/www.abcr.org.br $(24 / 11 / 00)$

BANCO MUNDIAL. Brasil transporte multimodal de carga: questões regulatórias selecionadas. Brasília: Banco Mundial, 1997. 57p. 
BAUMER, J. Gargalos dificultam escoamento da safra recorde. Estado de São Paulo. Economia - Últimas Notícias, São Paulo, 14 abr. 2001.

BEILOCK, R.; BONEVA, P.; JOTOVA, G.; KOSTADINOVA, K.; VASSILEVA, D. Road conditions, border crossing and freight rates in Europe and Western Asia. Transportation Quarterly, v.50, n.1, p.79-90, Winter 1996.

BEILOCK, R.; GARROD, P.; MIKLIUS, W. Freight charge variations in truck transportation markets: price discrimination or competitive pricing? American Agricultural Economics Association, v.68, n.2, p.226-236, May 1986.

BEILOCK, R.; STANCHEV, K. Road transport in the Balkans. Transportation Quarterly, v.51, n.4, p.103-116, Fall 1997.

BINKLEY, J. K.; HARRER, B.. Major determinants of ocean freight rates for grains: an econometric analysis. American Journal of Agricultural Economics, v.63, n.1, p.47-57, Feb. 1981.

BIRKLAND, C. The right tire equals lower costs. Fleet Equipament, v.22, n.10, p.4043, Oct. 1996.

BRASIL. Ministério dos Transportes. Os caminhos do Brasil. Brasília: Ministério dos transportes, 2000.51p.

BRASIL. Ministério da Agricultura e Abastecimento. Safra deve ser de 85,7 milhões de toneladas, anuncia Pratini de Moraes. http://www.agricultura.gov.br $(25 / 04 / 2000)$. 
BUCKLEY, P.; WESTBROOK, M.D. Market definition and assessing the competitive relationship between rail and truck transportation. Journal of Regional Science, v.31, n.3, p.329-346, Feb. 1991.

BYINGTON, R.; OLIN, G. An econometric analysis of freight rate disparities in US liner trades. Applied Economics, v.15, n.3, p.403-407, 1983.

CAIXETA FILHO, J.V.; SILVA, N.D.V.; GAMEIRO, A.H. et al. Competitividade no agribusiness: a questão do transporte em um contexto logístico (compact disc). In: FARINA, E.M.M.Q.; ZYLBERSZTAJN, D. (Coord.) Competitividade no agribusiness brasileiro. São Paulo: FEA/FIA/PENSA/USP, 1998a. v.6, parte A.

CAIXETA FILHO, J.V.; SILVA, N.D.V.; GAMEIRO, A.H. et al. Competitividade no agribusiness: a questão do transporte em um contexto logístico (compact disc). In: FARINA, E.M.M.Q.; ZYLBERSZTAJN, D. (Coord.) Competitividade no agribusiness brasileiro. São Paulo: FEA/FIA/PENSA/USP, 1998b. v.6, parte C.

CASTRO, N. Estrutura e desempenho do setor de transporte rodoviário de carga. Pesquisa e Planejamento Econômico, v.18, n.1, p.55-82, abr. 1988.

CASTRO, N.; CARRIS, L.; RODRIGUES, B. Custos de transportes e a estrutura espacial do comércio interestadual brasileiro. http://www.nemesis.gov.br $(11 / 11 / 2000)$

COMPANHIA BRASILEIRA DE ABASTECIMENTO. Exportações do setor agropecuário brasileiro. http://www.conab.gov.br (14/05/2000)

CONFEDERAÇÃO NACIONAL DO TRANSPORTE. O perfil sócio-econômico e as aspirações dos caminhoneiros no país. Belo Horizonte: SEST/SENAT, 1999a. 17p. 
CONFEDERAÇÃO NACIONAL DO TRANSPORTE. Pesquisa rodoviária CNT 1999. http://www.cnt.org.br (22/04/1999b)

CONFEDERAÇÃO NACIONAL DO TRANSPORTE. Pesquisa rodoviária CNT 2000. http://www.cnt.org.br (10/10/2000)

CROSSBORDER MONITOR. Company \& Industry. The Economist Intelligence United Limited, v.5, n.23, May, 1997. 2p.

DEPARTAMENTO NACIONAL DE ESTRADA DE RODAGEM. Anuário Estatístico - 1996. http://www.dner.gov.br (10/02/2001)

DESCARTES SYSTEMS GROUP INC. Energy Roadshow: user's guide (verson 1.3). Ontario: Canada, 1998. 484p.

EM ASSEMBLÉIA no RS, líder comunica final do movimento. Folha de São Paulo Folha Dinheiro. São Paulo, 7 maio. 2000a. p. 2-11.

E-VIEWS. Programa E-Views versão 3.0: programa automatizado para elaboração dos procedimentos econométricos (software). Quantitative Micro Software, 1998.

FORKENBROCK, D. J. External costs of intercity truck freight transportation. Transportation Research part A: Policy and practice, v.33, n.7-8, p.505-526, Sep.Nov. 1999.

FULTON, M.; HARRINGTON, D.H.; REINSEL, R.D. Trade, transportation, commodity and marketing policies: Canada - U.S. comparation. Canadian Journal of Agricultural Economics, Farms, Farms Families, and Farming Communities. n. especial, p.195-207, 1995. 
FUNDAÇÃO INSTITUTO BRASILEIRO DE GEOGRAFIA E ESTATÍSTICA. Sistema IBGE de Recuperação Automática. http://www.Sidra.ibge.gov.br $(01 / 05 / 2000)$

GARRIDO, R.A. Spatial interaction between the truck flows through the Mexico-Texas border. Transportation Research Parte A: Policy and Practice, v.34, iss.1, p.23-33, Jan. 1998.

GARRIDO, R.A.; MAHMASSANI, H.S. Forecasting freight transportation demand with the space-time multimodal probit model. Transportation Research Part B: Methodological, v.34, n.5, p.403-418, June 2000.

GFMI SOFTWARE. Programa Infoguia: programa automatizado para gerenciamento de viagens (software). Ribeirão Preto: GFMI Software, 1998.

GUJARATI, D.N. Basics econometrics. 3.ed. Singapura: McGraw-Hill, 1995. 837p.

GWILLIAM, K.M. La economia del transporte y el desarrolo. In: RUS, G.; NASH, C. (Coord.) Desarrollos recientes em economia del transporte. Madri: Civitas, 1998. cap. 8, p. 393-473.

HAUSER, R.J. Competitive forces in the U.S. inland grain transportation industry: a regional perspective. Logistics and Transportation Review, v.22, n.2, p.158-183, June 1986.

HOFFMANN, R.; VIEIRA, S. Análise de regressão: uma introdução à econometria. 3. ed. São Paulo: Hucitec, 1998. 379 p. 
HSU, J.L.; GOODWIN, B.K. Dynamic relationships in the market for ocean grain freighting service. Canadian Journal of Agricultural Economics, v.43, n.2, p.271284, Jul.1995.

INFORME SIFRECA. Piracicaba, v. 4, n. 37, maio 2000. 34p.

KERKVLIET, J.; MCMULLEN, B.S. The impact of unionization on motor carrier costs. Economic Inquiry, v.25, n.2, p.271-284, Apr. 1997.

KERR, J.D. Least square analysis of freight-rate anomalies. Australian Journal of Statistics, v.14, n.1, p. 63-67, 1972.

LABBE, M. The logic of cost allocation. Fleet Owner, v.94, n.3, p.30. Mar. 1999.

LAZZARINI, S.G.; NUNES, R. Competitividade do sistema agroindustrial da soja. (compact disc). In: FARINA, E.M.M.Q.; ZYLBERSZTAJN, D. (Coord.) Competitividade no agribusiness brasileiro. São Paulo: FEA/FIA/PENSA/USP, 1998.

MARTINS, R. S. Racionalização da infra-estrutura de transporte no estado do Paraná: o desenvolvimento e a contribuição das ferrovias para a movimentação de grãos e farelo de soja. Piracicaba, 1998. 216p. Tese (Doutorado) - Escola Superior de Agricultura "Luiz de Queiroz", Universidade de São Paulo.

MIKLIUS, W.; CASAVANT, K.L., GARROD, P.V. Estimation of demand for transportation of agricultural commodities. American Journal of Agricultural Economics, v.58, n.2, p.217-223, May 1976. 
MILJKOVIC, D.; PRICE, G.K.; HAUSER, R.J.; ALGOZIN, K.A. The barge and rail freight market for export-bound grain moviment from midwest to Mexican Golf: an econometric analysis. Transportation Research: Part E, v.36, n.2, p.127-137, June 2000 .

MINAHAN, T. Truckers battle back. Purchasing, v.121, n.9, p.51-52, Dec. 1996.

MINTEN, B.; KYLE, S. The effect of distance and road quality on food collection, marketing margins, and traders' wages: evidence from the former Zaire. Journal of Development Economics, v.60, n.2, p.467-495, 1999.

PAÍS parou por 4 dias esse ano. Folha de São Paulo, Folha Dinheiro. São Paulo, 13 dez. 1999. p. 3-4.

OLIVEIRA, J.C.V. Análise do transporte de soja, milho e farelo de soja na hidrovia Tietê-Paraná. Piracicaba, 1996. 136p. Dissertação (Mestrado) - Escola Superior de Agricultura "Luiz de Queiroz", Universidade de São Paulo.

OMAMO, S.W. Trasnport costs and smallholder cropping choices: an application to Siaya District, Kenya. American Journal of Agricultural Economics, v.80, n.1, p.116-123, Feb. 1998.

ORTÚZAR, J.D.; WILLUNSEN, L.G. Modelling Transport. Chichester: Jonh Wiley, 1990. $375 \mathrm{p}$.

PRENTICE, B.E.; BENELL, D. Determinants of empty returns by U.S. refrigerated trucks: conjoint analysis approach. Canadian Journal of Agricultural Economics, v. 40, n. 1, p. 109-127, Mar. 1992. 
ROSS, A. Road accidents: a global problem requiring urgent action. Road \& Highways Topic Note RH-2, June, 1999. p.1.

SMITH, A. Investigação sobre a natureza e as causas da riqueza das nações. São Paulo: Abril, 1974. 247p. (Os Pensadores, 28)

SINAL fechado: europeus bloqueiam combustível em protesto contra o preço da gasolina. Folha de São Paulo. São Paulo, 21 set. 2000b. p. 12-13.

SIQUEIRA K.; OLIVEIRA, E. Colheita alavanca vendas de pesados. O Carreteiro, v. 29, n. 308, p.2, abr. 2000.

SISTEMA DE INFORMAÇÃO DE FRETES. Planilha eletrônica com dados das movimentações de soja a granel nos principais trechos brasileiros. Piracicaba: SIFRECA, 2000. 1 disquete.

SOARES, M.G.; GALVANI, P.R.C.; CAIXETA FILHO, J.V. Transporte de soja em grãos e farelo de soja no Brasil. Preços Agrícolas, v. 11, n. 126, p.26, abr. 1997.

STUANI, R. Operação deve reduzir filas em Paranaguá. Estado de São Paulo. Economia: Últimas Notícias. São Paulo, 10 abr. 2001.

THOMPSON, H.L. Freight rate equations. Industrial and Engineering Chemistry, v.52, n.11, p.40A-44A, Nov. 1960.

VEENSTRA, A.W.; FRANSES, P.H. A co-integration approach to forecasting freight rates in the dry bulk shipping sector. Transportation Research - Part A: Policy and Pratice, v.31, n.6, p.447-458, Nov. 1997. 
WHITE, H. A heteroscedasticity - consistent covariance matrix estimator and a direct test for heteroscedasticity. Econometrica, v. 48, p. 817-838, 1980.

WORLD BANK GROUP. Why is the transport sector important? http://www.worldbank.org/html/fpd/transport/whytsimp.htm (19/04/2000)

WOUDSMA, C. Nafta and Canada-US cross-border freight transportation. Journal of Transport Geography, v.7, n.2, p.105-119, June 1999. 
APÊNDICES 


\section{APÊNDICE 1}

Tabela A - Relação das regiões constantes no conjunto de dados utilizados e não identificadas e os respectivos municípios utilizados como referência de localização

\begin{tabular}{ccc}
\hline Região não identificada & Estado & Município de referência \\
\hline Colorado & GO & Jataí \\
Espigão & GO & Brasília \\
Lagoa do Bauzinho & GO & Santa Helena \\
Maracanã & GO & Montividiu \\
Morro Vermelho & GO & Mineiros \\
Tapurah & GO & Rio Verde \\
Ana Terra & MT & Lucas do Rio Verde \\
Campos de Júlio & MT & Marilândia \\
Caravagio & MT & Sorriso \\
Carolina & MT & Primavera do Leste \\
Chapadão da Guiratinga & MT & Guiratinga \\
Chapadão dos Baús & MT & Costa Rica \\
Clevelândia & MT & Lucas do Rio Verde \\
Condomínio & MT & Campos Novos do Parecis \\
Deciolândia & MT & Campos Novos do Parecis \\
Eldorado & MT & Sorriso \\
Groslândia & MT & Nova Mutum \\
Itaquerê & MT & Primavera do Leste \\
Nova Ubiratã & MT & Jatobá \\
Pacoval & MT & Sorriso \\
Petrovina & MT & Alto Garça \\
Primaverinha & MT & Sorriso \\
S. Luiz Gonzaga & MT & Lucas do Rio Verde \\
Sapezal & MT & Brasnorte \\
Wipich & MT & Nova Mutum \\
\hline
\end{tabular}




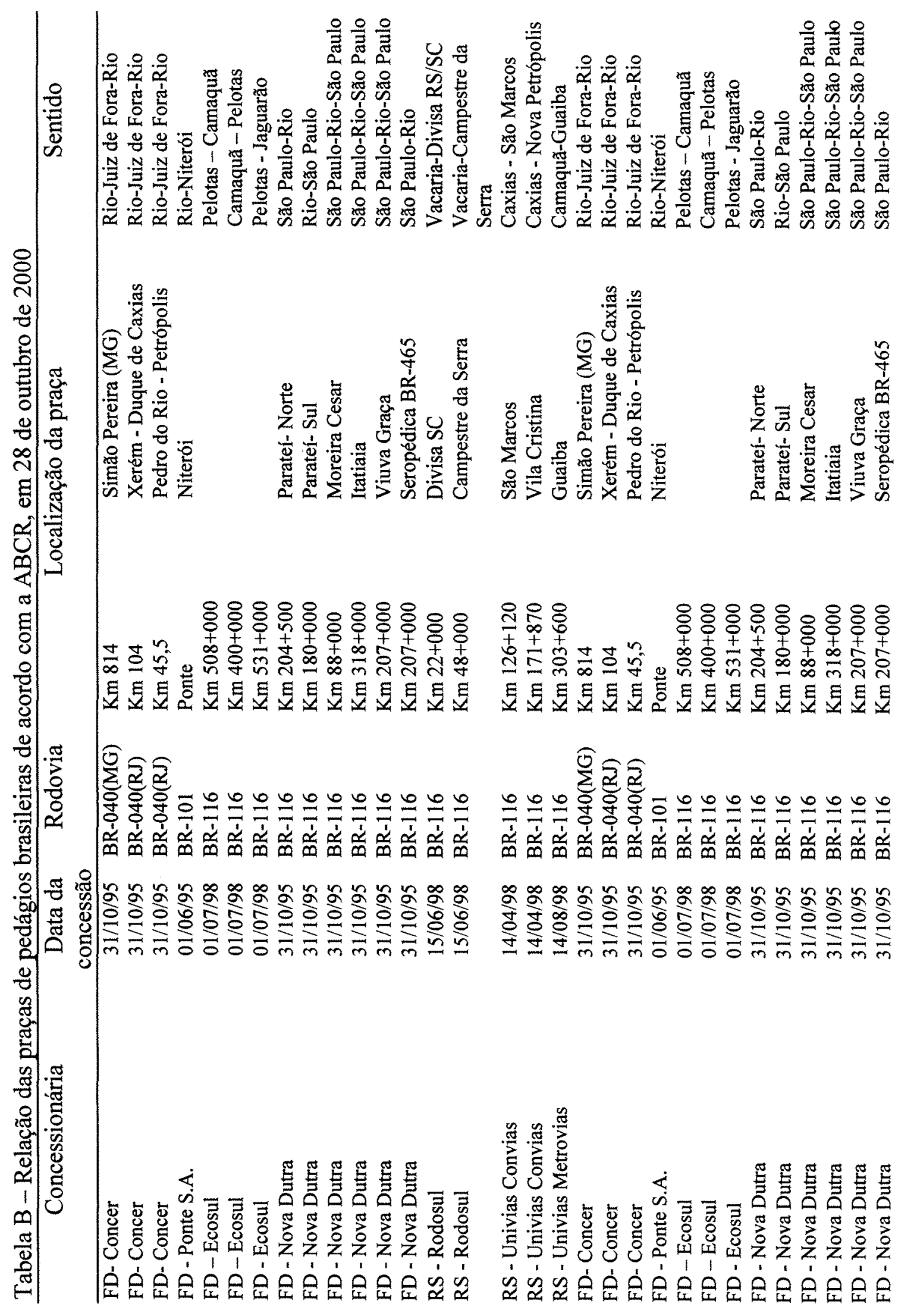




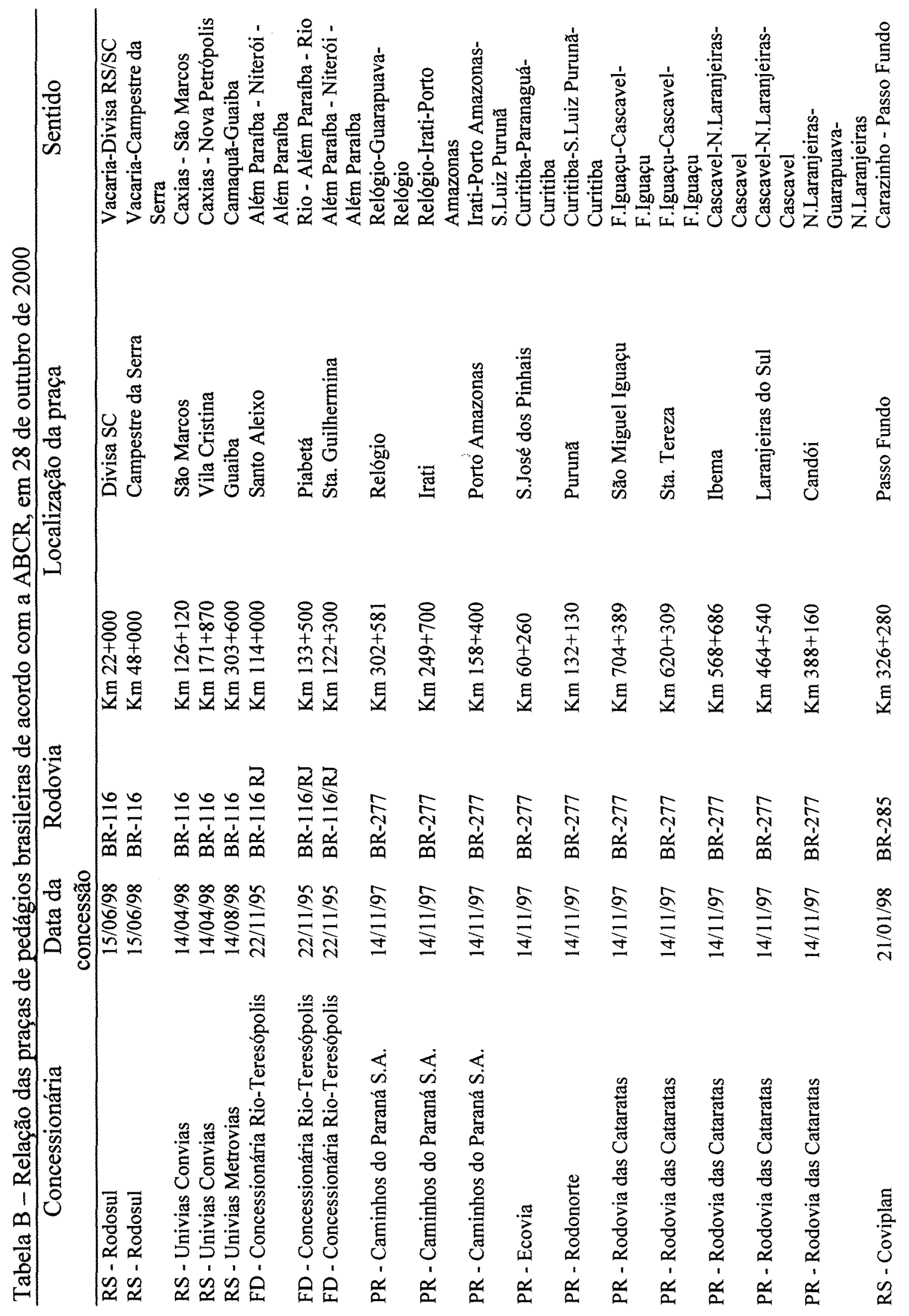




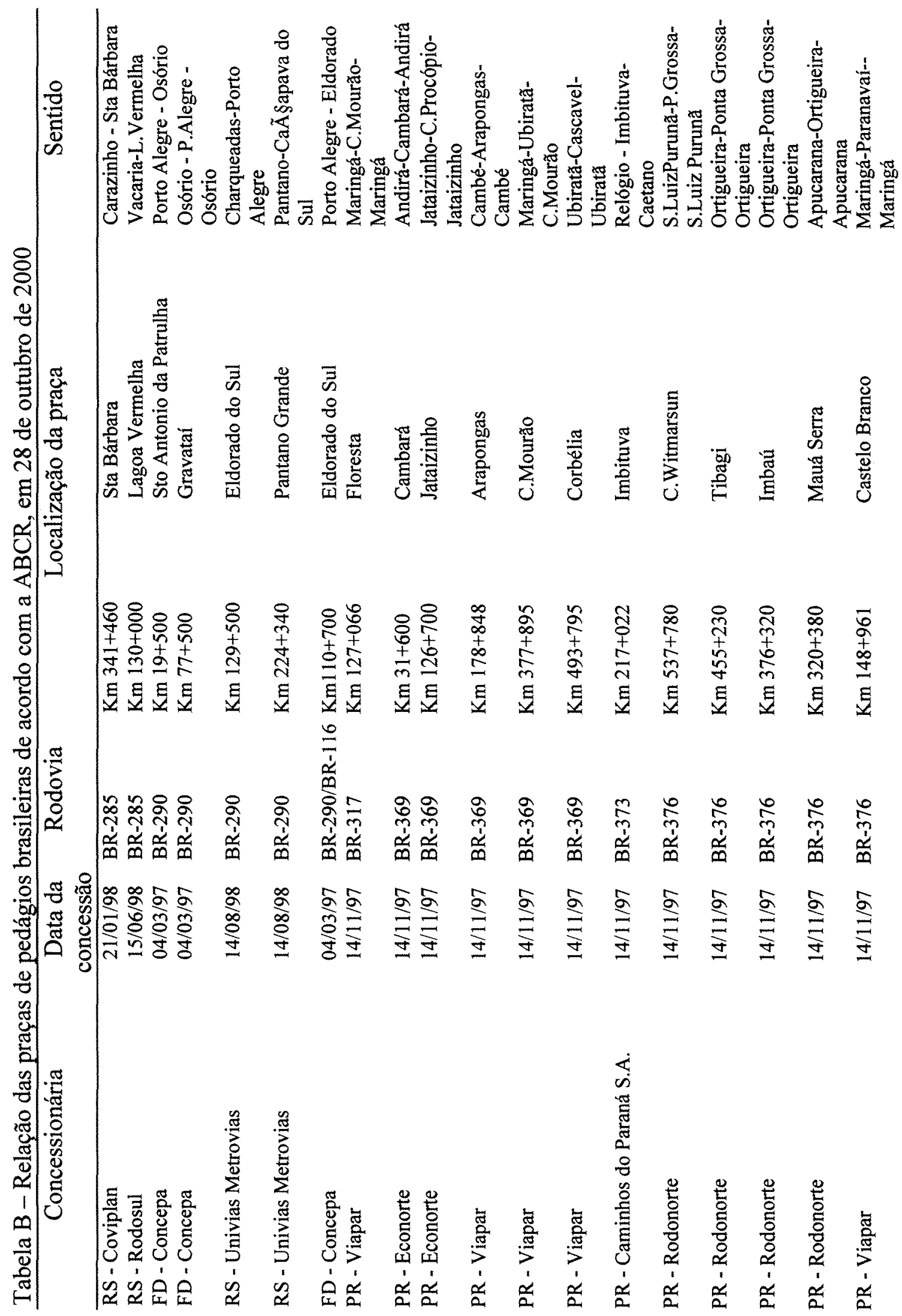




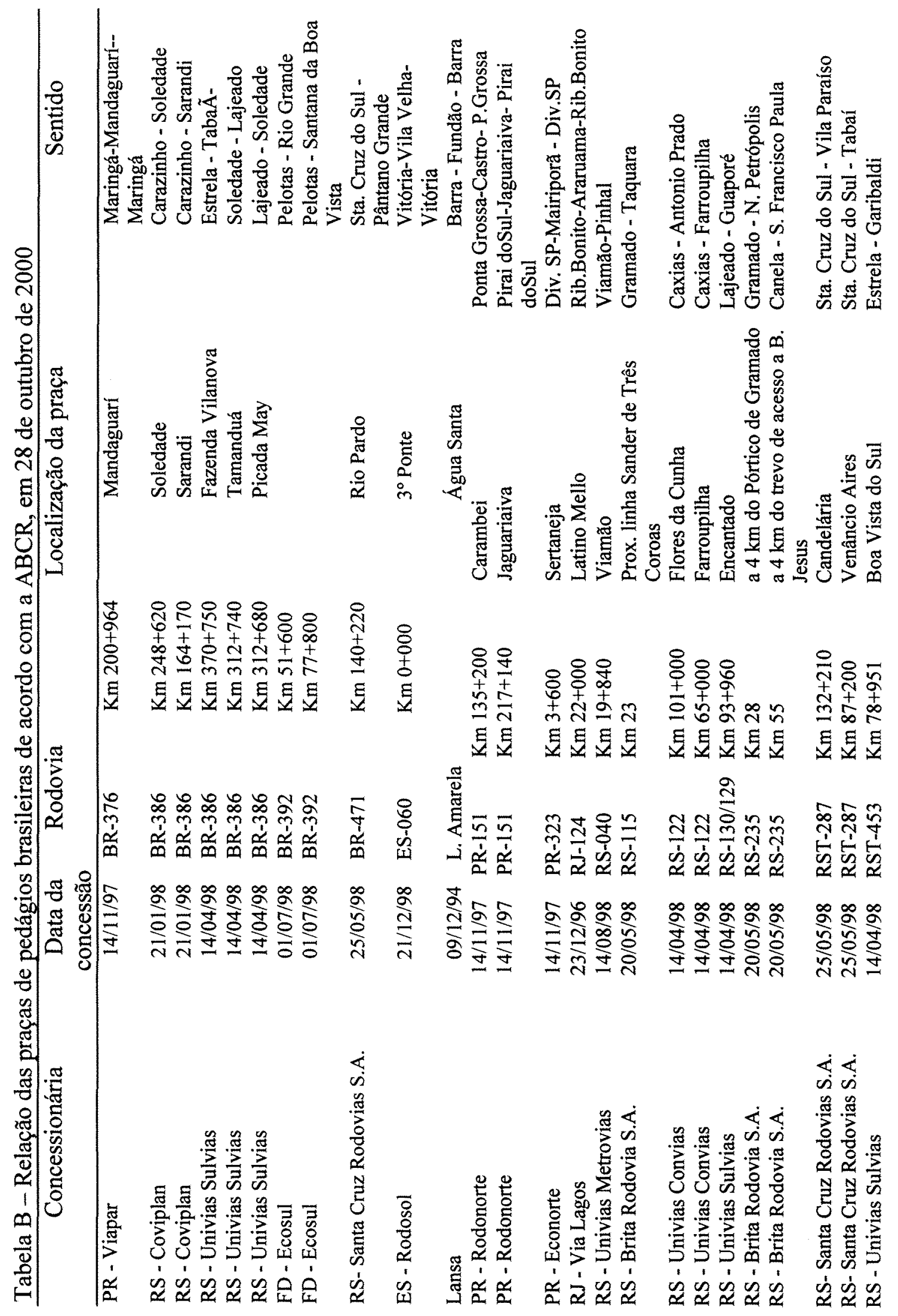




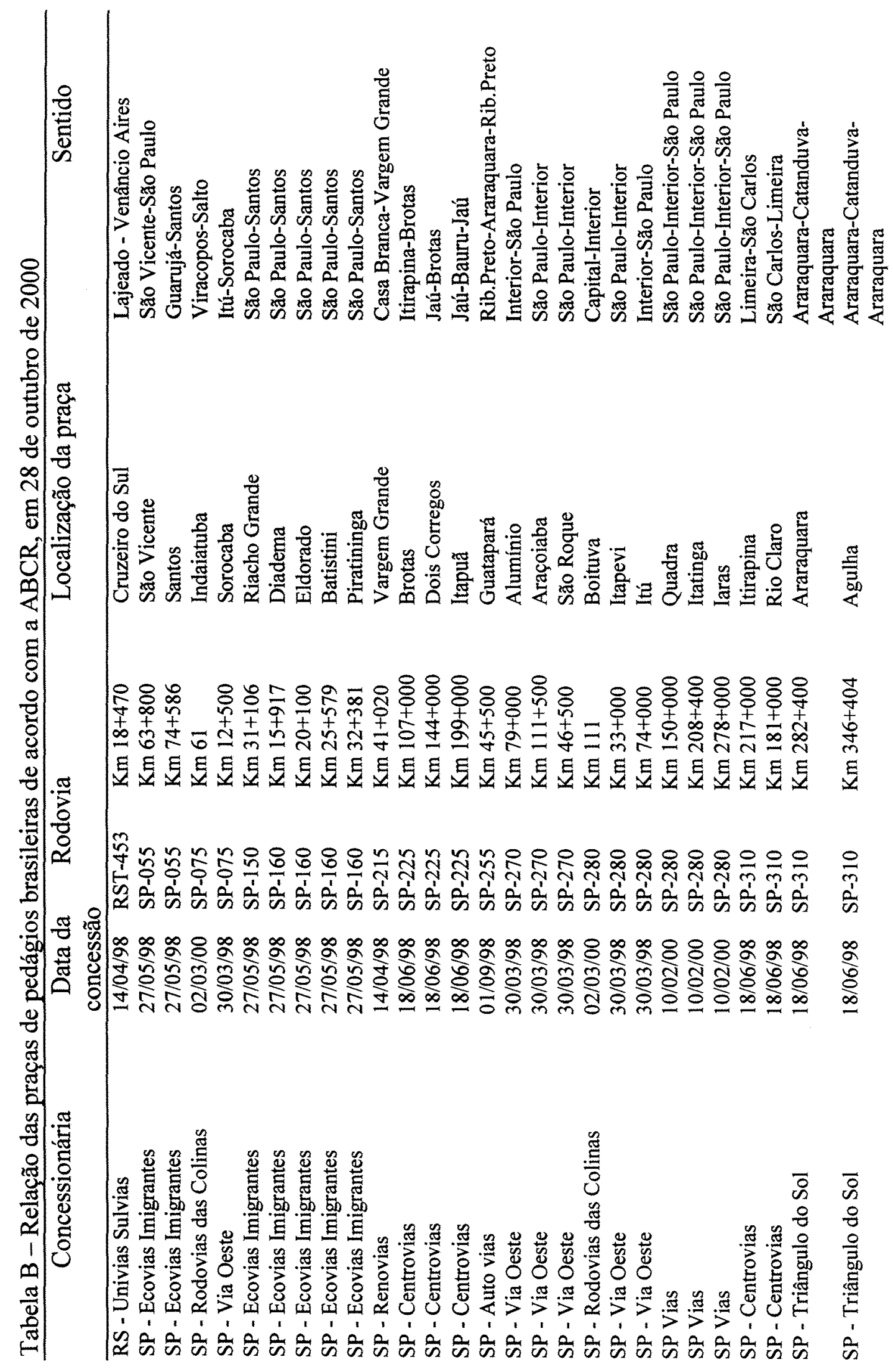




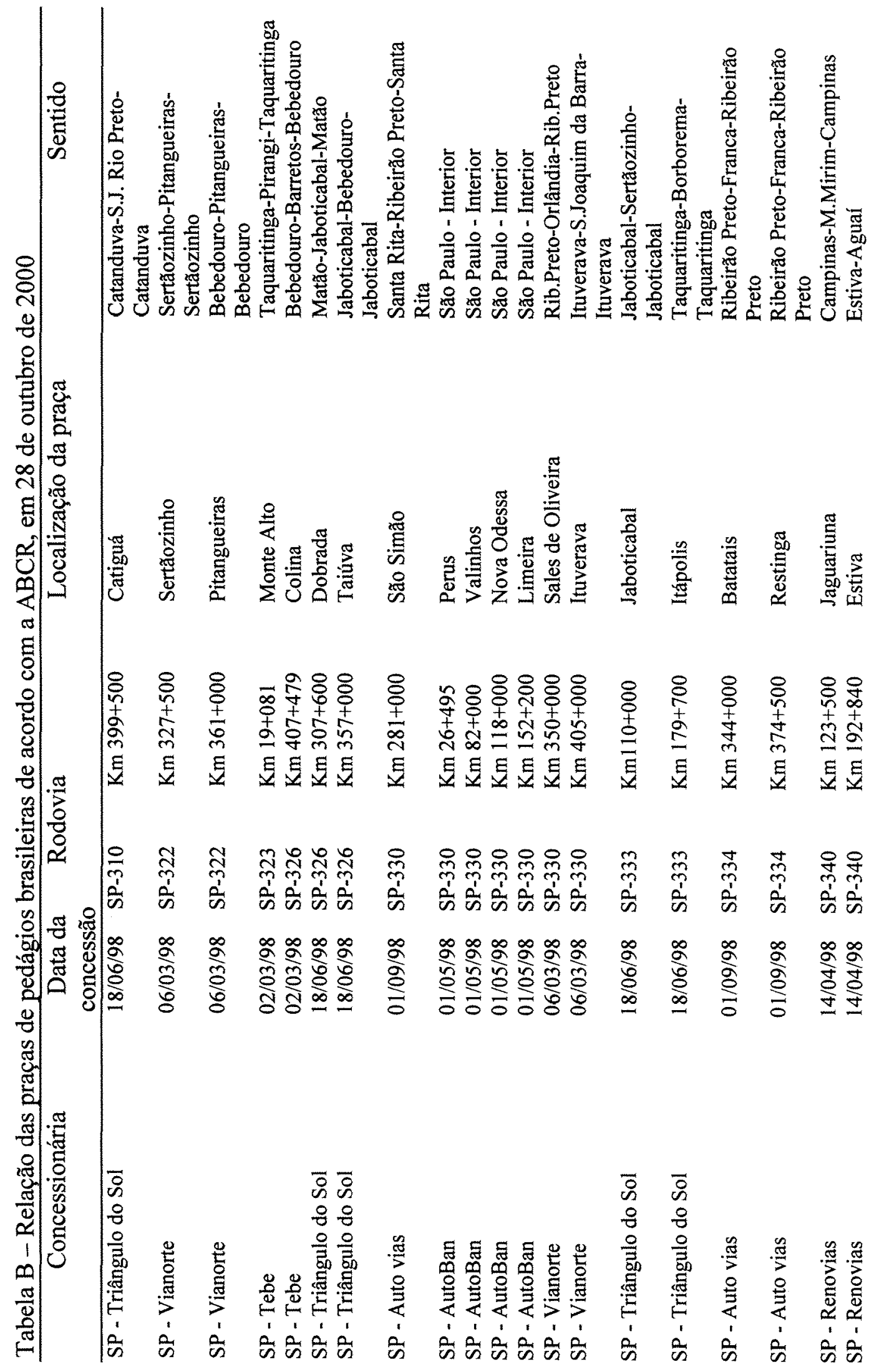




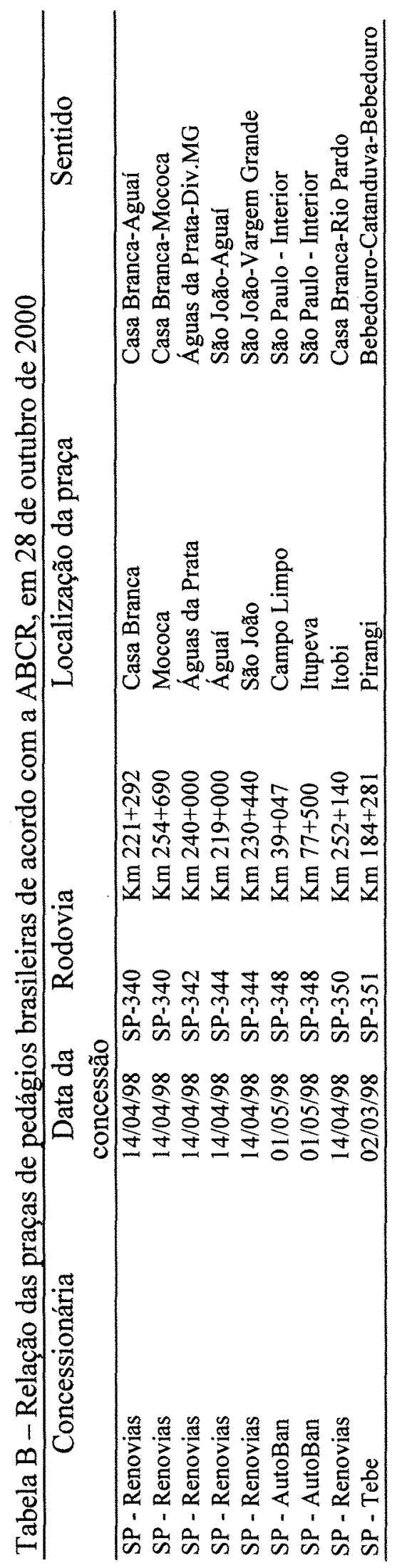


Tabela C - Amostra dos dados utilizados ${ }^{\mathrm{I}}$

\begin{tabular}{|c|c|c|c|c|c|c|c|}
\hline MESS/ANO & ORIGEM & DESTINO & $\begin{array}{c}\text { FRETE } \\
\text { (R\$/t) }\end{array}$ & $\begin{array}{l}\text { DISTÂNCIA } \\
(\mathrm{km})\end{array}$ & VIA & PEDÁGIO & RETORNO \\
\hline $3 / 1998$ & Alto Araguaia - MT & Uberlândia - MG & 608,00 & 34 & 0 & 0 & 0 \\
\hline $3 / 1998$ & Alto Garças - MT & Itumbiara - GO & 524,00 & 30 & 0 & 0 & 0 \\
\hline $1 / 1999$ & Acreúna - GO & Itumbiara - GO & 11,10 & 194 & 0 & 0 & 0 \\
\hline $1 / 1999$ & Estância - GO & São Simão - GO & 14,36 & 231 & 0 & 0 & 0 \\
\hline $1 / 1999$ & Parecis - MT & Santos - SP & 74,43 & 1.925 & 0 & 8 & 1 \\
\hline $3 / 1999$ & Mineiros - GO & Itumbiara - GO & 379,00 & 20 & 0 & 0 & 0 \\
\hline $3 / 1999$ & Mineiros - GO & Jataí - GO & 102,00 & 9 & 1 & 0 & 0 \\
\hline $3 / 1999$ & Wipich - MT & Cuiabá - MT & 350,00 & 28 & 0 & 0 & 0 \\
\hline $4 / 1999$ & Pontalina - GO & São Simão - GO & 319,00 & 18 & 0 & 0 & 0 \\
\hline $12 / 1999$ & Portelândia - GO & São Simão - GO & 15,78 & 323 & 0 & 0 & 0 \\
\hline $12 / 1999$ & Portelândia - GO & Itumbiara - GO & 20,29 & 413 & 0 & 0 & 0 \\
\hline $12 / 1999$ & Cascavel - PR & Ponta Grossa - PR & 21,13 & 377 & 1 & 4 & 0 \\
\hline $1 / 2000$ & Lucas do Rio Verde - MT & Ponta Grossa - PR & 69,28 & 1.912 & 1 & 1 & 0 \\
\hline $1 / 2000$ & Lucas do Rio Verde - MT & Paranaguá - PR & 79,49 & 2.115 & 1 & 5 & 1 \\
\hline $1 / 2000$ & Londrina - PR & Aracaju - SE & 111,06 & 2.350 & 1 & 3 & 0 \\
\hline $1 / 2001$ & Montividiu - GO & Campinas - SP & 40,31 & 862 & 0 & 6 & 0 \\
\hline $1 / 2001$ & Rio Verde - GO & Itumbiara - GO & 12,09 & 189 & 0 & 0 & 0 \\
\hline $3 / 2000$ & IV Centenário - PR & Paranaguá - PR & 579,00 & 37 & 1 & 4 & 1 \\
\hline $4 / 2000$ & Juranda - PR & Ponta Grossa - PR & 365,00 & 24 & 1 & 1 & 0 \\
\hline $4 / 2000$ & Sertanópolis - PR & Santos - SP & 559,00 & 26 & 1 & 6 & 1 \\
\hline $4 / 2000$ & Terra Roxa - PR & Paranaguá - PR & 679,00 & 44 & 1 & 10 & 1 \\
\hline $4 / 2000$ & Tibagi - PR & Ponta Grossa - PR & 97,00 & 13 & 1 & 1 & 0 \\
\hline $4 / 2000$ & Toledo - PR & Paranaguá - PR & 595,00 & 48 & 1 & 8 & 1 \\
\hline $4 / 2000$ & Ubiratã - PR & Paranaguá - PR & 559,00 & 41 & 1 & 4 & 1 \\
\hline $4 / 2000$ & Ubiratã - PR & Sertanópolis - PR & 307 & 20 & 1 & 1 & 0 \\
\hline
\end{tabular}

'Aqueles que estiverem interessados na série completa de dados, entrar em contato com o autor por email: goncilio@hotmail.com, ou como SIFRECA, sifreca@esalq.usp.br. 


\section{APÊNDICE 2}

Resultados dos testes econométricos

ENTRESSAFRA GO 98/99

Dependent Variable: FRETE

Method: Least Squares

Date: 07/09/01 Time: 20:00

Sample: 1153

Included observations: 153

White Heteroskedasticity-Consistent Standard Errors \& Covariance

\begin{tabular}{crcrr}
\hline \multicolumn{1}{c}{ Variable } & Coefficient & Std. Error & t-Statistic & Prob. \\
\hline C & 2.456227 & 0.364076 & 6.746463 & 0.0000 \\
KM & 0.046347 & 0.001300 & 35.66156 & 0.0000 \\
PEDAGIO & -0.440533 & 0.422463 & -1.042772 & 0.2988 \\
RETORNO & 1.260105 & 2.906276 & 0.433581 & 0.6652 \\
VIA & -0.808976 & 0.712944 & -1.134698 & 0.2583 \\
R-squared & 0.958693 & Mean dependent var & 18.95952 \\
Adjusted R-squared & 0.957577 & S.D. dependent var & 13.60454 \\
S.E. of regression & 2.802114 & Akaike info criterion & 4.930759 \\
Sum squared resid & 1162.073 & Schwarz criterion & 5.029793 \\
Log likelihood & -372.2031 & F-statistic & 858.7348 \\
Durbin-Watson stat & 0.982944 & Prob(F-statistic) & 0.000000 \\
\hline
\end{tabular}

\section{ENTRESSAFRA MT 98/99}

Dependent Variable: FRETE

Method: Least Squares

Date: 07/09/01 Time: 20:02

Sample: 199

Included observations: 99

White Heteroskedasticity-Consistent Standard Errors \& Covariance

\begin{tabular}{crlrr}
\hline \multicolumn{1}{c}{ Variable } & Coefficient & Std. Error & t-Statistic & Prob. \\
\hline C & 11.06752 & 1.054858 & 10.49195 & 0.0000 \\
KM & 0.031382 & 0.001080 & 29.05342 & 0.0000 \\
PEDAGIO & 0.354238 & 0.418383 & 0.846686 & 0.3993 \\
RETORNO & -1.408588 & 2.672941 & -0.526981 & 0.5994 \\
VIA & -1.994372 & 1.032240 & -1.932081 & 0.0564 \\
R-squared & 0.948853 & Mean dependent var & 44.55542 \\
Adjusted R-squared & 0.946676 & S.D. dependent var & 20.28292 \\
S.E. of regression & 4.683724 & Akaike info criterion & 5.975249 \\
Sum squared resid & 2062.104 & Schwarz criterion & 6.106316 \\
Log likelihood & -290.7748 & F-statistic & 435.9566 \\
Durbin-Watson stat & 1.419245 & Prob(F-statistic) & 0.000000 \\
\hline
\end{tabular}


ENTRESSAFRA PR 98/99

Dependent Variable: FRETE Method: Least Squares

Date: 07/09/01 Time: 20:04

Sample: 123

Included observations: 23

White Heteroskedasticity-Consistent Standard Errors \& Covariance

\begin{tabular}{crrrr}
\hline \multicolumn{1}{c}{ Variable } & Coefficient & Std. Error & t-Statistic & Prob. \\
\hline C & -6.494937 & 0.247369 & -26.25607 & 0.0000 \\
KM & 0.054924 & 0.000691 & 79.48764 & 0.0000 \\
PEDAGIO & -1.423547 & 0.679498 & -2.094998 & 0.0506 \\
RETORNO & 1.788502 & 2.520987 & 0.709445 & 0.4871 \\
VIA & 11.35540 & 2.031653 & 5.589244 & 0.0000 \\
R-squared & 0.988722 & Mean dependent var & 29.20150 \\
Adjusted R-squared & 0.986216 & S.D. dependent var & 33.86113 \\
S.E. of regression & 3.975497 & Akaike info criterion & 5.787837 \\
Sum squared resid & 284.4824 & Schwarz criterion & 6.034683 \\
Log likelihood & -61.56012 & F-statistic & 394.5090 \\
Durbin-Watson stat & 1.891665 & Prob(F-statistic) & 0.000000 \\
\hline
\end{tabular}

ENTRESSAFRA GO 99/00

Dependent Variable: FRETE

Method: Least Squares

Date: 07/09/01 Time: 20:06

Sample: 187

Included observations: 87

White Heteroskedasticity-Consistent Standard Errors \& Covariance

\begin{tabular}{crllr}
\hline \multicolumn{1}{c}{ Variable } & Coefficient & Std. Error & t-Statistic & Prob. \\
\hline C & 2.708723 & 0.485140 & 5.583387 & 0.0000 \\
KM & 0.046732 & 0.001810 & 25.81735 & 0.0000 \\
PEDAGIO & -0.129328 & 0.406242 & -0.318352 & 0.7510 \\
RETORNO & -2.018622 & 4.020070 & -0.502136 & 0.6169 \\
VIA & -0.655502 & 1.188769 & -0.551412 & 0.5829 \\
R-squared & 0.952089 & Mean dependent var & 22.33799 \\
Adjusted R-squared & 0.949752 & S.D. dependent var & 16.49829 \\
S.E. of regression & 3.698258 & Akaike info criterion & 5.509354 \\
Sum squared resid & 1121.523 & Schwarz criterion & 5.651073 \\
Log likelihood & -234.6569 & F-statistic & 407.3798 \\
Durbin-Watson stat & 1.553899 & Prob(F-statistic) & 0.000000 \\
\hline
\end{tabular}




\section{ENTRESSAFRA MT 99/00}

Dependent Variable: FRETE

Method: Least Squares

Date: 07/09/01 Time: 20:07

Sample: 183

Included observations: 83

White Heteroskedasticity-Consistent Standard Errors \& Covariance

\begin{tabular}{crlrr}
\hline \multicolumn{1}{c}{ Variable } & Coefficient & Std. Error & t-Statistic & Prob. \\
\hline C & 9.735815 & 0.987044 & 9.863603 & 0.0000 \\
KM & 0.031351 & 0.001627 & 19.27355 & 0.0000 \\
PEDAGIO & 1.742503 & 0.465033 & 3.747056 & 0.0003 \\
RETORNO & -2.866612 & 1.847378 & -1.551719 & 0.1248 \\
VIA & 0.330323 & 1.147315 & 0.287909 & 0.7742 \\
R-squared & 0.972546 & Mean dependent var & 47.50429 \\
Adjusted R-squared & 0.971138 & S.D. dependent var & 23.65940 \\
S.E. of regression & 4.019470 & Akaike info criterion & 5.678527 \\
Sum squared resid & 1260.179 & Schwarz criterion & 5.824241 \\
Log likelihood & -230.6589 & F-statistic & 690.7705 \\
Durbin-Watson stat & 1.563714 & Prob(F-statistic) & 0.000000 \\
\hline
\end{tabular}

\section{ENTRESSAFRA PR 99/00}

Dependent Variable: FRETE

Method: Least Squares

Date: 07/09/01 Time: 20:09

Sample: 122

Included observations: 22

White Heteroskedasticity-Consistent Standard Errors \& Covariance

\begin{tabular}{crlrr}
\hline Variable & Coefficient & Std. Error & t-Statistic & Prob. \\
\hline C & -1.881335 & 0.281187 & -6.690690 & 0.0000 \\
KM & 0.045794 & 0.000448 & 102.2769 & 0.0000 \\
PEDAGIO & -0.363083 & 0.513159 & -0.707545 & 0.4888 \\
RETORNO & -0.058863 & 1.305054 & -0.045104 & 0.9646 \\
VIA & 7.257299 & 1.956543 & 3.709246 & 0.0017 \\
R-squared & 0.994053 & Mean dependent var & 30.30561 \\
Adjusted R-squared & 0.992654 & S.D. dependent var & 28.44306 \\
S.E. of regression & 2.437830 & Akaike info criterion & 4.816810 \\
Sum squared resid & 101.0312 & Schwarz criterion & 5.064774 \\
Log likelihood & -47.98491 & F-statistic & 710.4194 \\
Durbin-Watson stat & 1.400475 & Prob(F-statistic) & 0.000000 \\
\hline
\end{tabular}


ENTRESSAFRA GO 00/01

Dependent Variable: FRETE

Method: Least Squares

Date: 07/09/01 Time: $20: 10$

Sample: 1115

Included observations: 115

White Heteroskedasticity-Consistent Standard Errors \& Covariance

\begin{tabular}{crlrr}
\hline \multicolumn{1}{c}{ Variable } & Coefficient & Std. Error & t-Statistic & Prob. \\
\hline C & 4.431094 & 0.325282 & 13.62233 & 0.0000 \\
KM & 0.040784 & 0.001215 & 33.56729 & 0.0000 \\
PEDAGIO & 0.416313 & 0.176068 & 2.364510 & 0.0198 \\
RETORNO & -0.950665 & 1.263105 & -0.752641 & 0.4533 \\
VIA & 0.707366 & 0.614170 & 1.151742 & 0.2519 \\
R-squared & 0.968734 & Mean dependent var & 19.88563 \\
Adjusted R-squared & 0.967597 & S.D. dependent var & 12.95041 \\
S.E. of regression & 2.331182 & Akaike info criterion & 4.573132 \\
Sum squared resid & 597.7849 & Schwarz criterion & 4.692477 \\
Log likelihood & -257.9551 & F-statistic & 852.0477 \\
Durbin-Watson stat & 1.387177 & Prob(F-statistic) & 0.000000 \\
\hline
\end{tabular}

\section{ENTRESSAFRA MT 00/01}

Dependent Variable: FRETE

Method: Least Squares

Date: 07/09/01 Time: 20:13

Sample: 174

Included observations: 74

White Heteroskedasticity-Consistent Standard Errors \& Covariance

\begin{tabular}{crllr}
\hline \multicolumn{1}{c}{ Variable } & Coefficient & Std. Error & t-Statistic & Prob. \\
\hline C & 4.659493 & 1.341257 & 3.473975 & 0.0009 \\
KM & 0.032916 & 0.001221 & 26.95086 & 0.0000 \\
PEDAGIO & 0.963765 & 0.613277 & 1.571501 & 0.1206 \\
RETORNO & 4.375878 & 4.759599 & 0.919379 & 0.3611 \\
VIA & 2.810802 & 1.445597 & 1.944389 & 0.0559 \\
R-squared & 0.916481 & Mean dependent var & 54.17380 \\
Adjusted R-squared & 0.911640 & S.D. dependent var & 23.94077 \\
S.E. of regression & 7.116500 & Akaike info criterion & 6.827886 \\
Sum squared resid & 3494.475 & Schwarz criterion & 6.983566 \\
Log likelihood & -247.6318 & F-statistic & 189.2910 \\
Durbin-Watson stat & 1.966762 & Prob(F-statistic) & 0.000000 \\
\hline
\end{tabular}




\section{ENTRESSAFRA PR 00/01}

Dependent Variable: FRETE

Method: Least Squares

Date: 07/09/01 Time: 20:14

Sample: 157

Included observations: 57

White Heteroskedasticity-Consistent Standard Errors \& Covariance

\begin{tabular}{crllr}
\hline \multicolumn{1}{c}{ Variable } & Coefficient & Std. Error & t-Statistic & Prob. \\
\hline C & 2.088682 & 1.551247 & 1.346454 & 0.1840 \\
KM & 0.044759 & 0.000609 & 73.44256 & 0.0000 \\
PEDAGIO & 0.139349 & 0.253452 & 0.549806 & 0.5848 \\
RETORNO & -0.492672 & 1.238995 & -0.397639 & 0.6925 \\
VIA & -0.421988 & 1.793479 & -0.235290 & 0.8149 \\
R-squared & 0.953270 & Mean dependent var & 22.32440 \\
Adjusted R-squared & 0.949676 & S.D. dependent var & 18.93446 \\
S.E. of regression & 4.247578 & Akaike info criterion & 5.814206 \\
Sum squared resid & 938.1798 & Schwarz criterion & 5.993421 \\
Log likelihood & -160.7049 & F-statistic & 265.1962 \\
Durbin-Watson stat & 1.873347 & Prob(F-statistic) & 0.000000 \\
\hline
\end{tabular}

\section{SAFRA GO 98}

Dependent Variable: FRETE

Method: Least Squares

Date: 07/09/01 Time: 20:15

Sample: 1105

Included observations: 105

White Heteroskedasticity-Consistent Standard Errors \& Covariance

\begin{tabular}{crllr}
\hline \multicolumn{1}{c}{ Variable } & Coefficient & Std. Error & t-Statistic & Prob. \\
\hline C & 6.107282 & 0.623165 & 9.800432 & 0.0000 \\
KM & 0.040612 & 0.001898 & 21.40188 & 0.0000 \\
PEDAGIO & 1.008982 & 0.363344 & 2.776933 & 0.0066 \\
RETORNO & -4.959565 & 2.691303 & -1.842812 & 0.0683 \\
VIA & -3.068525 & 1.041589 & -2.946004 & 0.0040 \\
R-squared & 0.961037 & Mean dependent var & 27.51939 \\
Adjusted R-squared & 0.959478 & S.D. dependent var & 17.82487 \\
S.E. of regression & 3.588149 & Akaike info criterion & 5.439598 \\
Sum squared resid & 1287.481 & Schwarz criterion & 5.565977 \\
Log likelihood & -280.5789 & F-statistic & 616.6310 \\
Durbin-Watson stat & 1.139532 & Prob(F-statistic) & 0.000000 \\
\hline
\end{tabular}




\section{SAFRA MT 98}

Dependent Variable: FRETE

Method: Least Squares

Date: 07/09/01 Time: $20: 16$

Sample(adjusted): 1187

Included observations: 187 after adjusting endpoints

White Heteroskedasticity-Consistent Standard Errors \& Covariance

\begin{tabular}{crllr}
\hline \multicolumn{1}{c}{ Variable } & Coefficient & Std. Error & t-Statistic & Prob. \\
\hline C & 9.429599 & 2.176567 & 4.332327 & 0.0000 \\
KM & 0.039579 & 0.001781 & 22.22693 & 0.0000 \\
PEDAGIO & 0.938246 & 0.373874 & 2.509526 & 0.0130 \\
RETORNO & 2.131497 & 3.953682 & 0.539117 & 0.5905 \\
VIA & -1.827053 & 1.156610 & -1.579663 & 0.1159 \\
R-squared & 0.900891 & Mean dependent var & 61.31114 \\
Adjusted R-squared & 0.898712 & S.D. dependent var & 27.91590 \\
S.E. of regression & 8.884432 & Akaike info criterion & 7.232852 \\
Sum squared resid & 14365.83 & Schwarz criterion & 7.319245 \\
Log likelihood & -671.2717 & F-statistic & 413.5892 \\
Durbin-Watson stat & 1.951880 & Prob(F-statistic) & 0.000000 \\
\hline
\end{tabular}

\section{SAFRA PR 98}

Dependent Variable: FRETE

Method: Least Squares

Date: 07/09/01 Time: 20:17

Sample(adjusted): 142

Included observations: 42 after adjusting endpoints

White Heteroskedasticity-Consistent Standard Errors \& Covariance

\begin{tabular}{crllr}
\hline \multicolumn{1}{c}{ Variable } & Coefficient & Std. Error & t-Statistic & Prob. \\
\hline C & 1.716244 & 0.861698 & 1.991701 & 0.0538 \\
KM & 0.054358 & 0.001200 & 45.31511 & 0.0000 \\
PEDAGIO & -1.175542 & 0.529110 & -2.221735 & 0.0325 \\
RETORNO & -0.602693 & 2.409332 & -0.250149 & 0.8039 \\
VIA & 4.882793 & 1.260939 & 3.872346 & 0.0004 \\
R-squared & 0.973719 & Mean dependent var & 28.67659 \\
Adjusted R-squared & 0.970878 & S.D. dependent var & 25.79414 \\
S.E. of regression & 4.401801 & Akaike info criterion & 5.913248 \\
Sum squared resid & 716.9065 & Schwarz criterion & 6.120114 \\
Log likelihood & -119.1782 & F-statistic & 342.7195 \\
Durbin-Watson stat & 1.766894 & Prob(F-statistic) & 0.000000 \\
\hline
\end{tabular}




\section{SAFRA GO 99}

Dependent Variable: FRETE Method: Least Squares

Date: 07/09/01 Time: $20: 19$

Sample: 1184

Included observations: 184

White Heteroskedasticity-Consistent Standard Errors \& Covariance

\begin{tabular}{|c|c|c|c|c|}
\hline Variable & Coefficient & Std. Error & t-Statistic & Prab. \\
\hline $\mathrm{C}$ & 5.798197 & 0.555382 & 10.44001 & 0.0000 \\
\hline $\mathrm{KM}$ & 0.040256 & 0.001771 & 22.72464 & 0.0000 \\
\hline PEDAGIO & 1.425580 & 0.508430 & 2.803888 & 0.0056 \\
\hline RETORNO & -4.312322 & 4.388496 & -0.982642 & 0.3271 \\
\hline VIA & 0.780125 & 1.176157 & 0.663283 & 0.5080 \\
\hline R-squared & 0.912587 & \multicolumn{2}{|l|}{ Mean depe } & 26.29909 \\
\hline Adjusted R-squared & 0.910634 & \multicolumn{2}{|c|}{ S.D. dependent var } & 18.01876 \\
\hline S.E. of regression & 5.386562 & \multirow{2}{*}{\multicolumn{2}{|c|}{$\begin{array}{l}\text { Akaike info criterion } \\
\text { Schwarz criterion }\end{array}$}} & 6.232489 \\
\hline Sum squared resid & 5193.694 & & & 6.319852 \\
\hline Log likelihood & -568.3890 & \multicolumn{2}{|c|}{ F-statistic } & 467.1886 \\
\hline Durbin-Watson stat & 1.786663 & \multicolumn{2}{|c|}{ Prob(F-statistic) } & 0.000000 \\
\hline
\end{tabular}

\section{SAFRA MT 99}

Dependent Variable: FRETE Method: Least Squares

Date: 07/09/01 Time: 20:20

Sample: 1272

Included observations: 272

White Heteroskedasticity-Consistent Standard Errors \& Covariance

\begin{tabular}{|c|c|c|c|c|}
\hline Variable & Coefficient & Std. Error & t-Statistic & Prab. \\
\hline C & 13.66204 & 1.785282 & 7.652593 & 0.0000 \\
\hline $\mathrm{KM}$ & 0.036326 & 0.001622 & 22.40157 & 0.0000 \\
\hline PEDAGIO & 1.596293 & 0.580129 & 2.751619 & 0.0063 \\
\hline RETORNO & 1.682638 & 3.065522 & 0.548891 & 0.5835 \\
\hline VIA & -0.258980 & 1.309213 & -0.197814 & 433 \\
\hline R-squared & 0.876339 & \multicolumn{2}{|c|}{ Mean dependent var } & 62.41826 \\
\hline Adjusted R-squared & 0.874486 & \multirow{2}{*}{\multicolumn{2}{|c|}{$\begin{array}{l}\text { S.D. dependent var } \\
\text { Akaike info criterion }\end{array}$}} & 27.60585 \\
\hline S.E. of regression & 9.780168 & & & 7.416802 \\
\hline Sum squared resid & 25539.00 & \multicolumn{2}{|c|}{ Schwarz criterion } & 7.483085 \\
\hline Log likelihood & -1003.685 & \multicolumn{2}{|c|}{ F-statistic } & 473.0325 \\
\hline Durbin-Watson stat & 1.655594 & \multicolumn{2}{|c|}{ Prob(F-statistic) } & 0.000000 \\
\hline
\end{tabular}


SAFRA PR 99

Dependent Variable: FRETE

Method: Least Squares

Date: 07/09/01 Time: 20:22

Sample: 150

Included observations: 50

White Heteroskedasticity-Consistent Standard Errors \& Covariance

\begin{tabular}{crlrr}
\hline \multicolumn{1}{c}{ Variable } & Coefficient & Std. Error & t-Statistic & Prob. \\
\hline C & 3.708805 & 1.256188 & 2.952428 & 0.0050 \\
KM & 0.054106 & 0.000812 & 66.65040 & 0.0000 \\
PEDAGIO & -0.349602 & 0.324359 & -1.077826 & 0.2869 \\
RETORNO & 2.847838 & 1.434179 & 1.985692 & 0.0532 \\
VIA & 1.963427 & 1.524160 & 1.288203 & 0.2043 \\
R-squared & 0.982406 & Mean dependent var & 32.48589 \\
Adjusted R-squared & 0.980842 & S.D. dependent var & 23.94455 \\
S.E. of regression & 3.314205 & Akaike info criterion & 5.328952 \\
Sum squared resid & 494.2780 & Schwarz criterion & 5.520154 \\
Log likelihood & -128.2238 & F-statistic & 628.1764 \\
Durbin-Watson stat & 2.512857 & Prob(F-statistic) & 0.000000 \\
\hline
\end{tabular}

\section{SAFRA GO 00}

Dependent Variable: FRETE

Method: Least Squares

Date: 07/09/01 Time: 20:23

Sample: 1106

Included observations: 106

White Heteroskedasticity-Consistent Standard Errors \& Covariance

\begin{tabular}{crllr}
\hline \multicolumn{1}{c}{ Variable } & Coefficient & Std. Error & t-Statistic & Prob. \\
\hline C & 7.635100 & 0.720315 & 10.59967 & 0.0000 \\
KM & 0.035666 & 0.001837 & 19.41065 & 0.0000 \\
PEDAGIO & 1.165137 & 0.357532 & 3.258833 & 0.0015 \\
RETORNO & -2.670136 & 2.605258 & -1.024903 & 0.3079 \\
VIA & -1.929192 & 1.395395 & -1.382542 & 0.1699 \\
R-squared & 0.896446 & Mean dependent var & 32.13349 \\
Adjusted R-squared & 0.892345 & S.D. dependent var & 18.30774 \\
S.E. of regression & 6.006914 & Akaike info criterion & 6.469720 \\
Sum squared resid & 3644.384 & Schwarz criterion & 6.595354 \\
Log likelihood & -337.8952 & F-statistic & 218.5849 \\
Durbin-Watson stat & 1.606812 & Prob(F-statistic) & 0.000000 \\
\hline
\end{tabular}


SAFRA MT 00

Dependent Variable: FRETE

Method: Least Squares

Date: 07/09/01 Time: 20:23

Sample: 1122

Included observations: 122

White Heteroskedasticity-Consistent Standard Errors \& Covariance

\begin{tabular}{crllr}
\hline Variable & Coefficient & Std. Error & t-Statistic & Prob. \\
\hline C & 11.32532 & 1.478143 & 7.661859 & 0.0000 \\
KM & 0.034744 & 0.001544 & 22.50611 & 0.0000 \\
PEDAGIO & 1.817543 & 0.811839 & 2.238797 & 0.0271 \\
RETORNO & 0.711275 & 5.677004 & 0.125291 & 0.9005 \\
VIA & 2.377707 & 1.608655 & 1.478072 & 0.1421 \\
R-squared & 0.914422 & Mean dependent var & 60.20364 \\
Adjusted R-squared & 0.911496 & S.D. dependent var & 28.17284 \\
S.E. of regression & 8.381300 & Akaike info criterion & 7.130003 \\
Sum squared resid & 8218.803 & Schwarz criterion & 7.244922 \\
Log likelihood & -429.9302 & F-statistic & 312.5436 \\
Durbin-Watson stat & 1.842576 & Prob(F-statistic) & 0.000000 \\
\hline
\end{tabular}

\section{SAFRA PR 00}

Dependent Variable: FRETE

Method: Least Squares

Date: 07/09/01 Time: 20:24

Sample: 1110

Included observations: 110

White Heteroskedasticity-Consistent Standard Errors \& Covariance

\begin{tabular}{crlrr}
\hline Variable & Coefficient & Std. Error & t-Statistic & Prob. \\
\hline C & 3.120938 & 0.352659 & 8.849730 & 0.0000 \\
KM & 0.046072 & 0.001584 & 29.09210 & 0.0000 \\
PEDAGIO & -0.229741 & 0.347891 & -0.660383 & 0.5105 \\
RETORNO & 3.510929 & 1.452449 & 2.417248 & 0.0174 \\
VIA & 2.347154 & 0.690775 & 3.397856 & 0.0010 \\
R-squared & 0.902538 & Mean dependent var & 24.50138 \\
Adjusted R-squared & 0.898825 & S.D. dependent var & 14.05695 \\
S.E. of regression & 4.471247 & Akaike info criterion & 5.877601 \\
Sum squared resid & 2099.165 & Schwarz criterion & 6.000350 \\
Log likelihood & -318.2680 & F-statistic & 243.0844 \\
Durbin-Watson stat & 1.528129 & Prob(F-statistic) & 0.000000 \\
\hline
\end{tabular}

